\title{
DINÂMICA DO BANCO DE SEMENTES E DE POPULAÇÕES DE PLANTAS DANINHAS NA CULTURA DO CITROS (CitruS sinensis (L.) Osbeck.) SUBMETIDA A DIFERENTES SISTEMAS DE MANEJO
}

\section{REGMA SIMONE XAVIER CAETANO}

ENGENHEIRA AGRONOMA

Orientador : Prof. Dr. PEDRO JACOB CHRISTOFFOLETI Co-orientador: Prof. Dr. RICARDO VICTORIA FILHO

Tese apresentada à Escola Superior de Agricultura 'Luiz de Queiroz', Universidade de São Paulo, para obtenção do título de Doutor em Agronomia, Área de Concentração: Fitotecnia.

PIRACICABA

Estado de São Paulo - Brasil

Fevereiro - 2000 


\title{
Dados Internacionais de Catalogação na Publicação (CIP) DIVISĀO DE BIBLIOTECA E DOCUMENTAÇĂO - Campus "Luiz de Queiroz"/USP
}

\author{
Caetano, Regma Simone Xavier \\ Dinâmica do banco de sementes e de populaçōes de plantas daninhas na cultura do \\ citros (Citrus sinensis (L.) Osbeck.)) submetida a diferentes sistemas de manejo / Regma \\ Simone Xavier Caetano. - - Piracicaba, 2000. \\ $105 \mathrm{p}$.
}

Tese (doutorado) - Escola Superior de Agricultura Luiz de Queiroz, 2000.

Bibliografia.

1. Banco de semente 2. Dinâmica populacional 3. Herbicida 4. Laranja pera 5. Leguminosa forrageira 6. Manejo 7. Planta daninha 8. População de planta 1. Título

$\operatorname{CDD} 632.58$ 
À Gilson, que partiu muito cedo e não pode ver o final do nosso trabalho.

Por todo o carinho e pelos belos momentos que juntos passamos. 


\section{AGRADECIMENTOS}

À DEUS, por ter-me concedido a vida;

À minha mãe Laura que sempre acreditou que a transformação do homem se dá pela educação;

Ao Prof. Pedro Jacob Christoffoleti pela paciência e dedicação na orientação dos trabalhos;

Ao Prof. Ricardo Victoria Filho, pela compreensão e apoio nos momentos difíceis, e na Co-orientação do trabalho;

Aos professores do Departamento de Produção Vegetal, pelos conhecimentos transmitidos e dedicação aos alunos;

Aos funcionários do laboratório de plantas daninhas, Luís Ferrari, Aparecido Mendes e Ony Silva, pelo auxílio na coleta das amostra de solo e identificação das plântulas.

As secretárias do Departamento de Produção vegetal, Ivete, Bete, Célia, Silvia e D. Helena pela amizade e dedicação;

A Coordenação do Curso de Pós-graduação em Fitotecnia, pela oportunidade de realização do Curso;

As familias do Sr. Petronílio, Chico, Clóvis e Luisinho pela amizade e apoio durante toda a nossa estada em Piracicaba;

Aos colegas do Curso de Pós-Graduação em Fitotecnia e de outros Cursos da ESALQ;

A Median, pela convivência e momentos felizes que passamos juntas;

A Jeane, Silvinha, Betânia, Joelson e Cláudio pela maravilhosa convivência no final do curso; 


\section{SUMÁRIO}

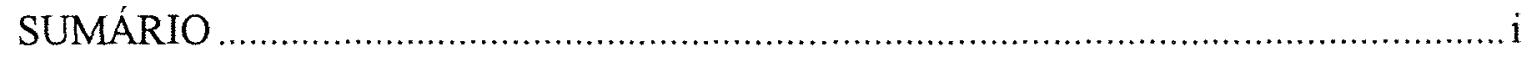

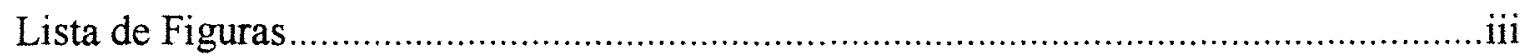

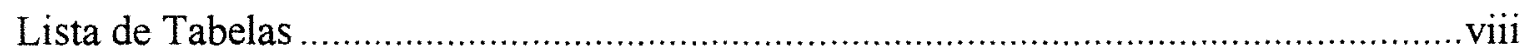

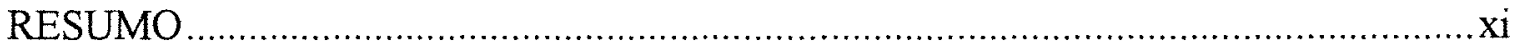

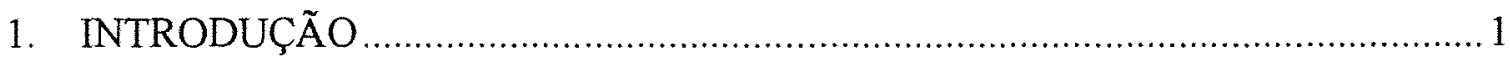

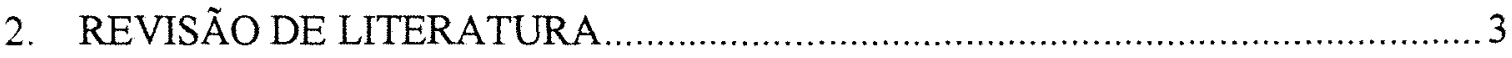

2.1 Banco de Sementes e aspectos metodológicos de sua quantificação.......................3

2.2 Germinação e Dormência de sementes ................................................................. 8

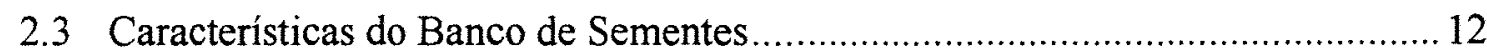

2.4 Dinâmica do banco de sementes .................................................................... 15

2.5 Efeito de práticas culturais sobre o banco de sementes …................................. 17

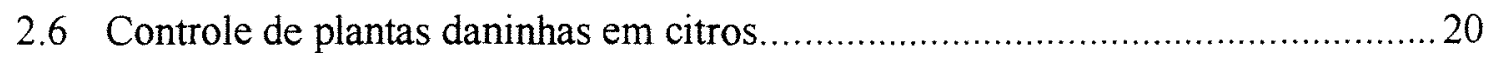

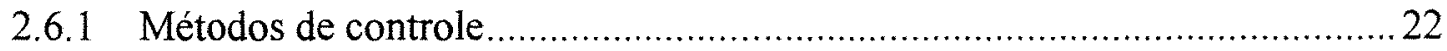

2.6.1.1 Controle mecânico $\quad 22$

2.6.1.2 Controle químico 23

2.4.1.3 Cobertura vegetal 24

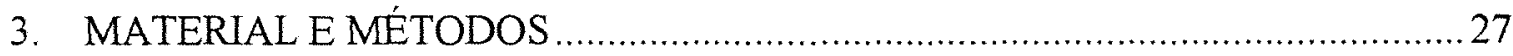

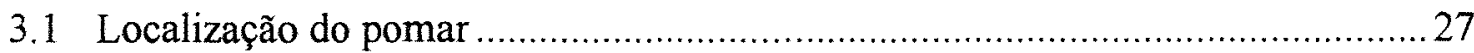

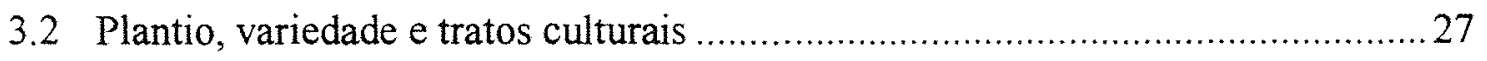

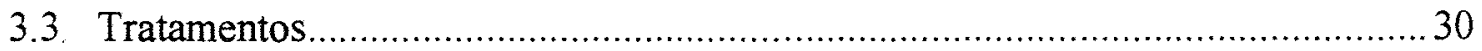

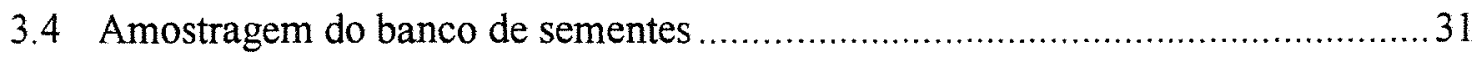

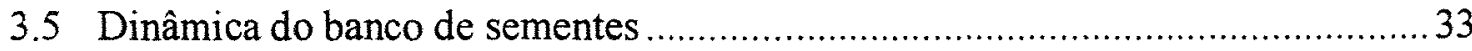




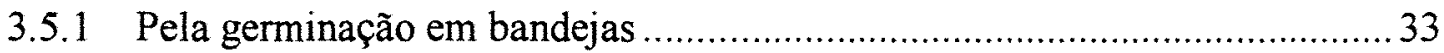

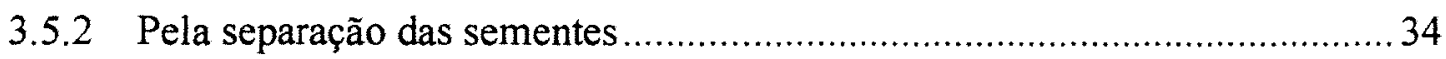

3.6 Delineamento experimental e análise estatística.................................................36

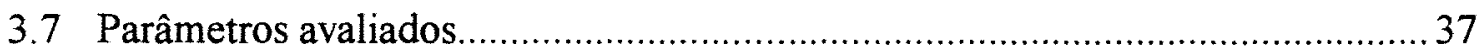

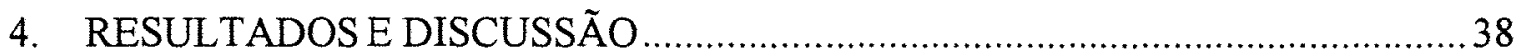

4.1 Emergência de plantas daninhas das amostras de solo em bandejas ...................38

4.1.1. Interação tratamento $x$ profundidade de amostragem na entrelinha, período seco do ano.

4.1.2. Interação tratamento $\mathrm{x}$ profundidade de amostragem na entrelinha, período chuvoso do ano.

4.1.3. Interação herbicida $x$ profundidade de amostragem, na linha de plantio, no período seco do ano.

4.1.4. Interação herbicida $x$ profundidade de amostragem, na linha de plantio, na

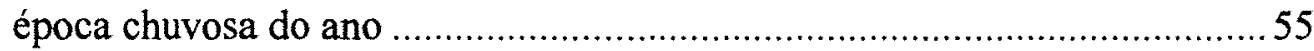

4.2 Contagem de sementes de plantas daninhas no solo ...........................................60

4.2.1 Interação herbicida $\mathrm{x}$ profundidade de amostragem, na linha de plantio, nas

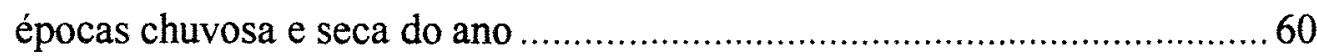

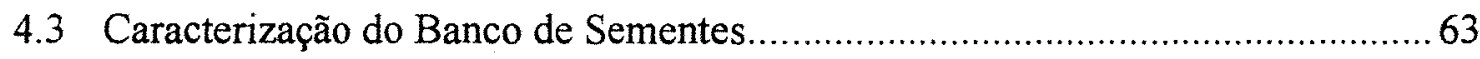

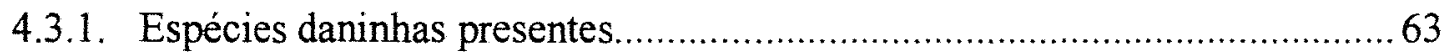

4.3.2. Dinâmica populacional e freqüência das espécies na entrelinha, para emergência em bandeja.

4.3.3. Dinâmica populacional e freqüência das espécies na linha de plantio, para emergência em bandeja

4.3.4. Dinâmica populacional e freqüência do banco de sementes, na entrelinha de plantio, no período chuvoso e seco

4.3.5 Dinâmica populacional e freqüência do banco de sementes, na linha de plantio, no período chuvoso e seco

5. CONCLUSÕES

6. REFERÊNCIAS BIBLIOGRÁFICAS 


\section{Lista de Figuras}

Figura 1. Dinâmica de bancos de sementes no solo.

Figura 2. Esquema de extração das sementes das amostras de solo para determinação do banco de sementes do solo.

Figura 3. Número médio de plântulas emergidas na primeira avaliação das amostras coletadas nos tratamentos na entrelinha da cultura, independente dos herbicidas usados na linha, no período seco do ano.

Figura 4. Número médio de plântulas emergidas na segunda avaliação das amostras coletadas nos tratamentos na entrelinha da cultura, independente dos herbicidas usados na linha, no período seco do ano.

Figura 5. Número médio de plântulas emergidas na terceira avaliação das amostras coletadas nos tratamentos na entrelinha da cultura, independente dos herbicidas usados na linha, no período seco do ano.

Figura 6. Número médio de plântulas emergidas na quarta avaliação das amostras coletadas nos tratamentos na entrelinha da cultura, independente dos herbicidas usados na linha, no período seco do ano.

Figura 7. Número médio de plântulas emergidas na primeira avaliação das amostras coletadas nos tratamentos na entrelinha da cultura, independente dos herbicidas usados na linha, no período chuvoso do ano.

Figura 8. Número médio de plântulas emergidas na segunda avaliação das amostras coletadas nos tratamentos na entrelinha da cultura, independente dos herbicidas usados na linha, no período chuvoso do ano 46 
Figura 9. Número médio de plântulas emergidas na terceira avaliação das amostras coletadas nos tratamentos na entrelinha da cultura, independente dos herbicidas usados na linha, no período chuvoso do ano.

Figura 10.Número médio de plântulas emergidas na quarta avaliação das amostras coletadas nos tratamentos na entrelinha da cultura, independente dos herbicidas usados na linha, no período chuvoso do ano.

Figura 11.Número médio de plântulas emergidas na primeira avaliação das amostras coletadas nos tratamentos na linha da cultura, independente dos tratamentos usados na entrelinha, no período seco do ano.

Figura 12.Número médio de plântulas emergidas na segunda avaliação das amostras coletadas nos tratamentos na linha da cultura, independente dos tratamentos usados na entrelinha, no período seco do ano

Figura 13.Número médio de plântulas emergidas na terceira avaliação das amostras coletadas nos tratamentos na linha da cultura, independente dos tratamentos usados na entrelinha, no período seco do ano.

Figura 14.Número médio de plântulas emergidas na quarta avaliação das amostras coletadas nos tratamentos na linha da cultura, independente dos tratamentos usados na entrelinha, no período seco do ano.

Figura 15 Número médio de plântulas emergidas na primeira avaliação das amostras coletadas nos tratamentos na linha da cultura, independente dos tratamentos usados na entrelinha, no período chuvoso do ano.

Figura 16.Número médio de plântulas emergidas na segunda avaliação das amostras coletadas nos tratamentos na linha da cultura, independente dos tratamentos usados na entrelinha, no período chuvoso do ano.

Figura 17.Número médio de plântulas emergidas na terceira avaliação das amostras coletadas nos tratamentos na linha da cultura, independente dos tratamentos usados na entrelinha, no período chuvoso do ano.

Figura 18. Número médio de plântulas emergidas na quarta avaliação das amostras coletadas nos tratamentos na linha da cultura, independente dos tratamentos usados na entrelinha, no período chuvoso do ano. 
Figura 19.Número médio de sementes obtidas das amostras coletadas nos tratamentos na linha da cultura, independente dos tratamentos usados na entrelinha, no período chuvoso do ano.

Figura 20.Número médio de sementes obtidas das amostras coletadas nos tratamentos na linha da cultura, independente dos tratamentos usados na entrelinha, no período seco do ano.

Figura21a.Frequência (\%) das espécies daninhas na entrelinha de plantioroçada/diuron - período chuvoso 64

Figura21b.Frequência (\%) das espécies daninhas na entrelinha de plantioroçada/diuron - período chuvoso 64

Figura22a.Frequência (\%) das espécies daninhas na entrelinha de plantio roçada/glyphosate - período chuvoso

Figura22b.Frequência (\%) das espécies daninhas na entrelinha de plantio roçada/glyphosate - periodo seco

Figura 23aFreqüência (\%) das espécies daninhas na entrelinha de plantio, glyfosate/diuron no período chuvoso

Figura 23bFrequêencia (\%) das espécies daninhas na entrelinha de plantio, glyfosate/diuron no período seco

Figura $24 \mathrm{aFrequência} \mathrm{( \% )} \mathrm{das} \mathrm{espécies} \mathrm{daninhas} \mathrm{na} \mathrm{entrelinha} \mathrm{de} \mathrm{plantio} \mathrm{-}$

glyphosate/glyphosate - período chuvoso

Figura 24bFrequência (\%) das espécies daninhas na entrelinha de plantio -

glyphosate/glyphosate - período seco.

Figura 25aFrequência (\%) das espécies daninhas na entrelinha de plantio -

guandu/diuron - período chuvoso 68

Figura 25bFrequência (\%) das espécies daninhas na entrelinha de plantio -

guandu/diuron - período seco .68

Figura 26aFrequência (\%) das espécies daninhas na entrelinha de plantio -

guandu/glyphosate- período chuvoso

Figura 26bFrequência (\%) das espécies daninhas na entrelinha de plantio -

guandu/glyphosate - periodo seco 
Figura 27aFrequência (\%) das espécies daninhas na entrelinha de plantio - lab-lab/diuron

- período chuvoso

Figura 27bFrequência (\%) das espécies daninhas na entrelinha de plantio - lab-

lab/diuron - período seco.

Figura 28aFrequência (\%) das espécies daninhas na entrelinha de plantio - lab-

lab/glyphosate - período chuvoso

Figura 28bFrequência (\%) das espécies daninhas na entrelinha de plantio - lab-

lab/glyphosate - período seco

Figura 29aFreqüência (\%) das espécies daninhas na entrelinha de plantio -

gradagem/diuron - período chuvoso

Figura 29bFrequência (\%) das espécies daninhas na entrelinha de plantio -

gradagem/diuron - período seco .73

Figura 30aFrequência (\%) das espécies daninhas na entrelinha de plantio - roçada/diuron

- periodo chuvoso 74

Figura 30bFrequência (\%) das espécies daninhas na entrelinha de plantio - roçada/diuron

- período seco 74

Figura 31aFrequência (\%) das espécies daninhas na linha de plantio -glyphosate nos diferentes tratamentos - período chuvoso.

Figura 31 bFrequência (\%) das espécies daninhas na linha de plantio - glyphosate nos

diferentes tratamentos - período seco.

Figura 32aFrequência (\%) das espécies daninhas na linha de plantio - diuron nos

diferentes tratamentos - período chuvoso

Figura 32bFrequência (\%) das espécies daninhas na linha de plantio - roçada/diuron -

período seco.

Figura 33aFrequência (\%) do banco de sementes na entrelinha de plantio - roçada -

período chuvoso do ano.

Figura 33 bFrequência (\%) do banco de sementes na entrelinha de plantio - roçada -

período seco do ano

Figura 34aFrequência (\%) do banco de sementes na entrelinha de plantio - glyphosate período chuvoso do ano 
Figura 34bFrequência (\%) do banco de sementes na entrelinha de plantio - glyphosate período seco do ano

Figura 35aFrequência (\%) do banco de sementes na entrelinha de plantio - guandu -

período chuvoso do ano.

Figura 35bFrequência (\%) do banco de sementes na entrelinha de plantio - guandu -

período seco do ano.

Figura 36aFrequência (\%) do banco de sementes na entrelinha de plantio - lab-lab -

período chuvoso do ano.

Figura 36bFrequência (\%) do banco de sementes na entrelinha de plantio - lab-lab -

período seco do ano.

Figura 37aFrequência (\%) do banco de sementes na entrelinha de plantio - gradagem período chuvoso do ano

Figura 37bFrequência (\%) do banco de sementes na entrelinha de plantio - gradagem -

periodo seco do ano.

Figura 38aFrequência (\%) das espécies daninhas na linha de plantio - glyphosate nos

diferentes tratamentos - período chuvoso do ano

Figura 38bFrequência (\%) do banco de sementes na linha de plantio - glyphosate nos

diferentes tratamentos, no período seco do ano

Figura 39aFrequência (\%) do banco de sementes na linha de plantio - diuron nos

diferentes tratamentos, no período chuvoso do ano

Figura 39bFrequência (\%) do banco de sementes na linha de plantio - diuron nos

diferentes tratamentos, no período seco do ano 


\section{Lista de Tabelas}

Tabela 1. Precipitação $(\mathrm{mm})$, umidade relativa (\%), temperatura máxima, mínima e média $\left({ }^{\circ} \mathrm{C}\right)$ de Piracicaba/SP, nos anos de 1997 e 1998.

Tabela 2. Análise química do solo para a entrelinha e linha de plantio em duas profundidades.

Tabela 3. Análise granulométrica do solo para a entrelinha e linha de plantio em duas profundidades.

Tabela 4. Tratamentos utilizados na linha e entrelinha de plantio na cultura do citros.

Tabela 5. Resultados da análise preliminar do número de amostragem e variância do número de sementes.

Tabela 6. Esquema da análise de variância do experimento 36

Tabela 7. Número médio de plântulas que emergiram das amostras colocadas em bandejas nos diversos tratamentos $\mathrm{x}$ profundidades, na entrelinha da cultura, primeira avaliação, período seco do ano.

Tabela 8. Número médio de plântulas que emergiram das amostras colocadas em bandejas nos diversos tratamentos $\mathrm{x}$ profundidades, na entrelinha da cultura, segunda avaliação, período seco do ano.

Tabela 9. Número médio de plântulas que emergiram das amostras colocadas em bandejas nos diversos tratamentos $x$ profundidades, na entrelinha da cultura, terceira avaliação, período seco do ano.

Tabela 10. Número médio de plântulas que emergiram das amostras colocadas em bandejas nos diversos tratamentos $\mathrm{x}$ profundidades, na entrelinha da cultura, quarta avaliação, período seco do ano. 
Tabela 11. Número médio de plântulas que emergiram das amostras colocadas em bandejas nos diversos tratamentos $\mathrm{x}$ profundidades, na entrelinha da cultura, primeira avaliação, período chuvoso do ano

Tabela 12. Número médio de plântulas que emergiram das amostras colocadas em bandejas nos diversos tratamentos $\mathrm{x}$ profundidades, na entrelinha da cultura, segunda avaliação, período da chuva.

Tabela 13. Número médio de plântulas que emergiram das amostras colocadas em bandejas nos diversos tratamentos $\mathrm{x}$ profundidades, na entrelinha da cultura, terceira avaliação, período da chuva.

Tabela 14. Número médio de plântulas que emergiram das amostras colocadas em bandejas nos diversos tratamentos $\mathrm{x}$ profundidades, na entrelinha da cultura, quarta avaliação, período da chuva.

Tabela 15. Número médio de plântulas que emergiram das amostras colocadas em bandejas nos diversos tratamentos $\mathrm{x}$ profundidades, na linha da cultura, primeira avaliação, período seco do ano.

Tabela 16. Número médio de plântulas que emergiram das amostras colocadas em bandejas nos diversos tratamentos $\mathrm{x}$ profundidades, na linha da cultura, segunda avaliação, periodo seco do ano.

Tabela 17 Número médio de plântulas que emergiram das amostras colocadas em bandejas nos diversos tratamentos $\mathrm{x}$ profundidades, na linha da cultura, terceira avaliação, período seco do ano.

Tabela 18. Número médio de plântulas que emergiram das amostras colocadas em bandejas nas duas profundidades, na linha da cultura, quarta avaliação, período seco do ano.

Tabela 19. Número médio de plântulas que emergiram das amostras colocadas em bandejas nos diversos tratamentos $\mathrm{x}$ profundidades, na linha da cultura, primeira avaliação, no período chuvoso.

Tabela 20. Número médio de plàntulas que emergiram das amostras colocadas em bandejas nos diversos tratamentos $\mathrm{x}$ profundidades, na linha da cultura, segunda avaliação, no período chuvoso. 
Tabela 21. Número médio de plântulas que emergiram das amostras colocadas em bandejas nos diversos tratamentos $\mathrm{x}$ profundidades, na linha da cultura, terceira avaliação, no período da chuva

Tabela 22. Número médio de plântulas que emergiram das amostras colocadas em bandejas nos diversos tratamentos $\mathrm{x}$ profundidades, na linha da cultura, quarta avaliação, no período da chuva. 59

Tabela 23. Número de sementes por amostras da interação herbicida x profundidade, na linha de plantio, no período chuvoso do ano. 61

Tabela 24. Número de sementes por amostras da interação herbicida x profundidade, na linha de plantio, no periodo seco do ano. 


\title{
DINÂMICA DO BANCO DE SEMENTES E DE POPULAÇÕES DE PLANTAS DANINHAS NA CULTURA DO CITROS (Citrus sinensis (L.) Osbeck) SUBMETIDA A DIFERENTES SISTEMAS DE MANEJO
}

\author{
Autora: REGMA SIMONE XAVIER CAETANO \\ Orientador : PEDRO JACOB CHRISTOFFOLETI \\ Co-orientador: RICARDO VICTORIA FILHO
}

\section{RESUMO}

O estudo da dinâmica populacional e do banco de sementes das plantas daninhas foi realizado com o objetivo de avaliar os efeitos de diferentes sistemas de manejo utilizados na cultura de citrus. O trabalho foi realizado em um pomar de laranja 'Pera' (Citrus sinensis (L.) Osbeck), da área experimental do Departamento de Produção Vegetal, ESALQ/USP, Piracicaba/SP. Os tratamentos consistiram na utilização dos herbicidas diuron na dose de $2,0 \mathrm{Kg}$ i.a/ha. em pré-emergência e glyphosate $1,08 \mathrm{Kg}$ i.a/ha. em pós-emergência na linha de plantio, associado a cinco práticas de manejo na entrelinha da cultura: gradagem, roçada, dose reduzida de glyphosate $(0,540 \mathrm{Kg}$ i.a/ha. $)$, e as leguminosas guandu (Cajanus cajan) e lab-lab (Dolichos lablab). Foram retiradas amostras de solo da entrelinha e linha de citros nas profundidades de 0-10 cm e 10-20 cm, em duas épocas, ou seja de maior precipitação pluviométrica (época chuvosa) e de déficits hídricos (época seca). As amostras 
foram homogeneizadas, colocadas em bandejas de alumínio, formando uma camada de $2 \mathrm{~cm}$ e levadas para germinar em condições de casa-de-vegetação. Avaliou-se a emergência das plântulas durante quatro etapas, onde as espécies eram contadas, identificadas e arrancadas. A partir das amostras de solo, retirou-se também $100 \mathrm{~g}$ para identificação e contagem das sementes. Para isso foi necessário utilizar metodologia especifica de extração, empregando-se carbonato de potássio como agente dispersante e centrifugação a 10.000 rpm, por 15 minutos para separação das sementes dos componentes minerais do solo. O sobrenadante resultante foi peneirado e as sementes colocadas em placa de petri, para posterior identificação com auxílio de uma lupa. Os resultados foram analisados estatisticamente através da análise de variância, e as médias obtidas foram comparadas através do teste de Tukey. A partir dos resultados obtidos pode-se concluir que os tratamentos mecânicos gradagem e roçagem proporcionam maior porcentagem de número de plantas, enquanto que as leguminosas diminuem a germinação das plantas daninhas. A camada de $0-10 \mathrm{~cm}$ apresentou maior número de sementes para todos os tratamentos e não ocorreu modificações significativas na flora para as duas épocas estudadas. A aplicação de herbicidas como forma de manejo de plantas daninhas em citros influi na distribuição do banco de sementes no perfil do solo, sendo que o glyphosate permite a maior formação populacional de sementes de plantas daninhas quando comparado com o diuron na linha de citros ou com os demais tratamentos usados na entrelinha. 
WEED SEEDBANK AND POPULATION DYNAMIC IN CITRUS CROP (Citrus sinensis (L.) Osbeck) UNDER DIFFERENT MANAGEMENT SYSTEMS

\section{Author: REGMA SIMONE XAVIER CAETANO \\ Adviser: PEDRO JACOB CHRISTOFFOLETI Co-adviser: RICARDO VICTORIA FILHO}

\section{SUMMARY}

A population and seedbank dynamic study was conducted to evaluate the effects of different management systems used in the Brazilian citrus crop. The experiment was installed in a citrus orchard of Citrus sinensis ( $L$.) Osbeck cV. Pera, located at the experimental area of ESALQ/USP, Piracicaba, SP Brazil. The treatments in the citrus row were the herbicides diuron at $2,0 \mathrm{Kg}$ a.i./ha in pre-emergence and glyphosate $1,08 \mathrm{Kg}$ a.i./ha in post-emergence conditions of the weeds, associated with five inter-row treatments: mechanical (disking and mowing), reduced rate of glyphosate $(0,540 \mathrm{Kg}$ a.i./ha), and the green manure Cajanus cajan and Dolichos lablab. Two soil samples were collected from the row and inter-row of each treatment, depths of $0-10 \mathrm{~cm}$ and $10-20 \mathrm{~cm}$, being one at the rainy season and the other during the dry season. Part of the samples were homogenized in aluminum trays and then placed in the greenhouse. It was evaluated the seedling emergence four times, pulling out the emerged plants right after counting. One hundred grams of the soil samples 
were used for counting the seeds through specific methodology of seed extraction from the soil, using potassium carbonate for dispersion and centrifugation at $10.000 \mathrm{rpm}$ for $15 \mathrm{~min}$. The supernatant was sieved, dried, air cleaned and than placed in petri dishes for weed seed identification. Analysis of variance and average comparisons by Tukey test of the significant differences were applied in the results. It was concluded from the results that the mechanical management treatments mowing and disking allowed building up the higher weed seedbank and seedling emergence, however green manure suppressed weed germination. The soil layer of $0-10 \mathrm{~cm}$ showed a greater number of seeds for all treatments and did not show significant differences on the weed flora in both time studied (rainy and dry season). The application of ghyphosate for weed management in citrus alter the distribution of the weed seed bank in the soil profile, since glyphosate allows the formation of bigger population of weed seeds when compared to diuron sprayed in the citrus row or to all other treatments used in the inter-row. 


\section{INTRODUÇÃO}

Uma planta é considerada daninha quando cresce em local onde não é desejada, causando interferência negativa nas atividades do homem. As plantas daninhas que ocorrem em ecossistemas agrícolas, podem afetar o desenvolvimento das plantas cultivadas, provocando danos à produtividade e condução do sistema produtivo.

$\mathrm{Na}$ literatura há diversos relatos sobre a competição das plantas daninhas com plantas cultivadas pelos fatores produtivos como água, nutrientes, luz, causando prejuízos na produção e qualidade do produto; são também hospedeiras de pragas e patógenos. Por estas razões estas plantas são alvo de constante controle nas sistemas produtivos econômicos.

As espécies daninhas são caracterizadas por apresentarem uma alta capacidade de adaptação ao ambiente, geralmente fotossintetizam pelo ciclo $\mathrm{C}_{4}$, produzem grande quantidade de sementes, dos quais a maioria são dormentes. A dormência é o fenômeno pelo qual sementes de uma determinada espécie, mesmo sendo viáveis e em condições ambientais propicias, deixam de germinar (Carvalho \& Nakagawa, 1983). Ela é a principal causa da sobrevivência das sementes de plantas daninhas no solo, provocando infestações prolongadas (Chadoeuf-Hannel, 1985), permitindo a formação dos chamados bancos de sementes.

O banco de sementes é uma reserva de sementes viáveis no solo presentes na superfície ou em profundidade. Esta reserva constitui a origem do ciclo de vida das espécies anuais, sendo a causa fundamental da sua persistência (Fernández-Quintanilla et al.,1991). 
Nos solos agrícolas, o banco de sementes de plantas daninhas é constituído em grande parte pelas sementes oriundas da disseminação por animais e homem. Mas, nestas áreas, grande parte do banco de sementes é proveniente da disseminação de plantas daninhas não controladas ou que escapam aos métodos de controle utilizados.

Nos estudos de banco de sementes, as técnicas de amostragem constitui um fator importante. Roberts (1981) cita que a forma mais simples é observar a germinação e emergência das plântulas no próprio local. No entanto, a técnica mais utilizada é colocar amostras de solo em casa-de-vegetação, para que as sementes presentes germinem. Estes métodos geralmente subestimam o banco, pois as sementes de plantas daninhas apresentam diferentes fluxos de germinação. Utilizam-se também métodos de separação física das sementes, através de um conjunto de peneiras elou com substâncias que promovam a flotação do solo e centrifugação em alta rotação.

Então, sabendo-se da existência do banco de sementes de plantas daninhas no solo, procurou-se conhecer essa reserva de sementes em pomar de laranja 'Pera', no qual foi aplicado diferentes manejos na linha e entrelinha de plantio; como o banco de sementes é influenciado pela profundidade de trabalho do solo, procurou-se também avaliar esse fator. 


\section{REVISÃO DE LITERATURA}

\subsection{Banco de Sementes e aspectos metodológicos de sua quantificação}

O termo banco de sementes tem sido adotado para designar as reservas de sementes viáveis no solo, em profundidade e na sua superfície (Roberts, 1981). Para Baker (1989) o banco ou reserva de sementes é uma agregação de sementes não germinadas mas, potencialmente capazes de substituir plantas adultas anuais que desapareceram por causa natural ou não, ou perenes, susceptíveis à doenças, distúrbios ou consumo por animais. Segundo o mesmo autor, o potencial de substituir espécies é primordial, visto que, se as sementes permanecessem enterradas em grande profundidade, elas não formariam um banco eficiente. Simpson et al., (1989) enfatizam que todas as sementes viáveis presentes no solo ou misturados com a serrapilheira constitui o banco de sementes.

Esta reserva de sementes constitui a origem do ciclo da vida das espécies anuais, sendo a causa fundamental da sua persistência; em plantas perenes, além do banco de sementes, ocorre 0 banco de propágulos vegetativos como tubérculos, rizomas e estolões (Fernández-Quintanilla et al., 1991). Ela também é um arquivo de informações ou memória das condições ambientais passadas, sendo um fator importante do potencial da comunidade de responder a condições no passado e no futuro (Templeton \& Levin, 1979).

Os estudos com banco de sementes iniciaram com Darwin em 1859, quando observou um grande número de plântulas e de sementes em amostras provenientes do fundo de um lago. No entanto, Petersen em 1882 foi quem 
primeiro observou a ocorrência da reserva de sementes em profundidade (Roberts, 1981). Após, Brenchley (1918) e Champness \& Moris (1948) continuaram os estudos de bancos de sementes e Kropác (1966) e Roberts (1970) com trabalhos de reserva de sementes em solos cultivados.

Os bancos de sementes em solos cultivados tem sido mais amplamente estudado que outros tipos, devido ao grande significado da agricultura. Em áreas agrícolas, o conhecimento desta reserva de sementes viáveis está relacionada com os estudos pertinentes às plantas daninhas. Através deste, pode-se construir modelos de estabelecimentos populacionais ao longo do tempo, possibilitando a definição de programas estratégicos de controle (Martins \& Silva 1994). O conhecimento das taxas de emergência de espécies nessas áreas podem servir para adequar manejos de solo e da cultura, que devem resultar na racionalização do uso de herbicidas (Voll et al., 1996).

O banco de sementes do solo é utilizado para estudar as relações quantitativas entre a sua população e a da flora infestante (Dessaint et al., 1990). Com essas informações, pode-se elaborar índices de predição e modelos de emergência, permitindo prever infestações futuras e definir medidas de manejo adequadas (Barralis \& Chadoeuf, 1987; Fernández-Quintanilla, 1988).

Um dos fatores importantes no estudo do banco de sementes esta relacionado com as técnicas utilizadas na sua determinação. Christoffoleti \& Caetano (1998) em revisão sobre banco de sementes, encontraram diferentes metodologias que podem ser utilizadas na determinação do banco de sementes. A observação 'in situ' da emergência de plântulas pode dar uma indicação geral sobre o tamanho e a composição do banco de sementes. No entanto, este método não é preciso (Mortimer, 1990), pois as sementes podem permanecer viáveis no solo por um longo período sem germinar e, algumas sementes germinadas não chegam a emergir devido as condições ambientais desfavoráveis ou profundidade de enterrio excessiva. 
A técnica mais utilizada é a determinação do número de sementes colocando-se amostra de solo em local apropriado, geralmente casa-devegetação, permitindo que as sementes germinem (Roberts, 1981).

Os métodos de germinação geralmente subestimam o banco de sementes, isto porque as sementes das plantas daninhas apresentam diferentes fluxos de germinação, podendo germinar ou não durante a avaliação (Gross, 1990).

Há também os métodos de separação física das sementes, através da passagem do solo por um conjunto de peneiras. Essas técnicas são bastantes trabalhosas e requerem longo tempo e algumas vezes causam detrimento na viabilidade das sementes (Standifer, 1980; Bulher \& Maxwell, 1993).

A técnica de separação física foi desenvolvida por Malone (1967) e depois adaptada por diversos autores como Bulher \& Maxwell (1993); Luschei et al. (1998).

Têm-se introduzido novas técnicas de separação de sementes do solo, utilizando-se substâncias que promovem a flotação do solo, como o carbonato de potássio $\left(\mathrm{K}_{2} \mathrm{CO}_{3}\right)$, e centrifugação em alta rotação. A centrifugação é utilizada para separar os constituintes do solo com diferentes densidades.

Ball \& Miller (1989) compararam duas técnicas de estimativa do banco de sementes, a) separação física por uso de peneiras e flotação, b) colocação do solo em bandejas em ambiente de casa-de-vegetação. Eles concluíram que as duas técnicas foram apropriadas para detectar diferenças entre tratamentos, de um experimento de avaliação de diferentes tipos de preparo de solo e uso de herbicidas.

Dentro da metodologia de estudo de banco de sementes, não se tem uma definição exata quanto ao número e o volume de solo a ser amostrado. Geralmente, nesses estudos, o custo de amostragem e os recursos disponiveis como tempo, espaço e trabalho físico, tem ordenado uma escolha arbitraria 
mas razoável quanto ao número e tamanho da amostra (Benoit et al., 1989). Porém, Kropác (1966) ressalta que como consenso geral, é mais vantajoso terse um grande número de pequenas amostras, do que um pequeno número de grandes amostras.

Esta afirmativa é confirmada por Bigwood \& Inouye (1988), quando observaram que a precisão da estimativa do número de sementes pode ser melhorada, tomando-se um grande número de pequenas amostras, utilização de sub-amostragens ou por unidades totais com muitas sub-unidades de pequeno tamanho.

No intuito de resolver esses problemas, diversos estudos foram conduzidos nos últimos anos com o objetivo de otimizar a amostragem do banco e consequentemente, obter informações suficientes sobre a abundância de sementes, estimando o banco corretamente (Barralis et al., 1986; Benoit et al., 1989; Dessaint et al., 1990). Estes estudos estão relacionados com o número de amostra e a sua variância.

De acordo com Benoit et al. (1989) a análise de variância do número de sementes da amostra é inversamente proporcional ao número de amostras. Então, quanto maior o número de sementes em uma amostra por área, menor será a variância e o número de amostras necessárias para estimar o banco de sementes. A relação entre a variância e o número de sementes por amostra sugere um padrão exponencial decrescente, sendo que, quando o número de amostras é dobrado a variância diminui pela metade.

Exemplificando o que foi relatado acima, os mesmos autores sugerem que cerca de 60 a 75 amostras são necessárias para quantificar 0 banco de sementes em área cultivada com milho. Para áreas com grande quantidade de sementes ou com zona de agregação de sementes, deve-se obter de 100 a 200 sementes por tratamento para estimativa adequada do banco (Goyeau \& Flabet, 1982; Barralis et al., 1986; Lopez et al., 1988).

Com relação ao diâmetro do amostrador de solo, Roberts \& Neilson (1982) salientam que o diâmetro do trado não deve exceder a 2,5 centímetros, 
embora o grupo de pesquisadores da European Weed Research Council recomende $4,5 \mathrm{~cm}$ (Barralis et al., 1986). Benoit et al., (1989) testaram três diferentes tamanhos de amostrador de solo (1,9;2,7 e 3,3 centimetros), para avaliar a população de Chenopodium spp. no solo. Os autores não encontraram nenhuma diferença do efeito dos diâmetros, quando os volumes de solo explorado eram iguais.

A profundidade de amostragem está em função do tipo de vegetação presente e do objetivo da pesquisa. Em solos cultivados, recomenda-se retirar a amostra na profundidade de cultivo; nessas áreas, cerca de $90 \%$ ou mais das sementes encontram-se nos primeiros 20 centímetros, com densidade populacional decrescente a medida em que aumenta-se a profundidade (Roberts \& Neilson, 1982; Fernández-Quintanilla,1988; Yenish et al., 1992; Granatos \& Torres, 1993).

As populações de sementes no solo são freqüentes e erroneamente assumidas como sendo homogêneas e com distribuição normal. Segundo Benoit et al., (1989) o problema em descrever essa distribuição está associado com uma heterogeneidade inerente. Na maioria das vezes as sementes são lançadas próximo à planta-mãe, embora a maior parte das espécies abundantes freqüentemente apresentam distribuição normal; já as menos abundantes apresentam distribuição agregada ou de Poisson (Goyeau \& Flabet, 1982).

Os bancos de sementes são grandemente influenciados pelas diversas práticas de cultivo (Roberts \& Dawkins, 1967; Roberts \& Neilson, 1982; Derkesen et al., 1993), seja na sua composição quanto na distribuição ao longo do perfil do solo (Yenish et al., 1992) e tamanho (Barberi et al., 1998).

O banco de sementes no solo é utilizado para estudar as relações quantitativas entre a sua população e a flora infestante (Dessaint et al., 1990; Granatos \& Torres, 1993). Com as suas informações, pode-se elaborar índices de predição e de modelos de emergência, permitindo prever infestações futuras 
e definir medidas de manejo adequadas (Barralis \& Chadoeuf, 1987; Fernández-Quintanilla, 1988).

Simpson et al. (1989) consideram que os principais problemas metodológicos no estudo do banco de sementes são: heterogeneidade dos métodos de amostragem, número insuficiente de amostras, não amostrar o solo ao longo do ano e por mais de um ano, não utilização de mecanismos de quebra de dormência, bem como fornecimento de condições ideais requeridas para germinação, além de análises estatísticas inadequadas das informações obtidas.

\subsection{Germinação e Dormência de sementes}

A semente é um estágio dormente no ciclo de vida do vegetal, sendo capaz de sobreviver a condições adversas, sob baixos niveis de atividade metabólica. Assim sendo, a mais importante propriedade demográfica das sementes é a capacidade de permanecerem dormentes e viáveis no solo. No entanto, a simples quebra desse estado de dormência não proporciona ao indivíduo sucesso reprodutivo (Gorresio-Roizman, 1993).

A dormência é o fenômeno pelo qual sementes de uma determinada espécie, mesmo sendo viáveis e tendo todas as condições ambientais, deixam de germinar (Carvalho \& Nakagawa, 1983). Para Naylor (1983) a dormência da semente é uma característica genética especial, sendo objeto de seleção (Jain, 1982) e resultante da adaptação das espécies ao ambiente no qual foram originadas (Vegis, 1964) O grau de dormência no entanto, pode ser modificado pelas condições ambientais durante o desenvolvimento da semente na plantamãe (Gutterman, 1982).

Este fenômeno previne a germinação das sementes formadas em determinadas épocas (Humphreys, 1981), afim de evitar que as plântulas enfrentem durante o seu desenvolvimento periodos desfavoráveis, como inverno rigoroso ou seca. 
A dormência é um mecanismo primário que regula os diversos modelos de germinação (Buhler et al., 1997); as sementes apresentam diferentes fluxos de germinação, mesmo dentro de uma mesma espécie, como também em espécies diferentes. Esta variabilidade na germinação leva a uma heterogeneidade dos estados de dormência das sementes presentes na camada superficial do solo ou enterradas nele, dificultando previsões de futuras infestações (Montégut, 1975).

Sementes não dormentes são capazes de germinar facilmente em condições favoráveis de umidade, temperatura e oxigênio. Quando uma semente não germina ou quando a germinação ocorre com dificuldade mesmo em ambiente favorável, elas são consideradas dormentes (Côme, 1982).

A dormência parece ser governada pela natureza das modificações que ocorrem antes e após a sua disseminação natural (Khan, 1980/1981); ela também é influenciada por fatores genéticos e ambientais (Murdoch \& Ellis, 1992). Como exemplo, as sementes provenientes da mesma planta-mãe tem diferentes graus de dormência, dependendo das condições ambientais, época de desenvolvimento e posição da semente na inflorescência (Gutterman, 1980/1981; Dekker et al., 1996). Essas modificações dependem das características próprias das sementes e dos fatores ambientais a que elas estão submetidas (Chadoeuf-Hannel, 1985).

As espécies silvestres geralmente apresentam dormência, enquanto que as plantas cultivadas após o processo de seleção durante a domesticação das espécies, perderam este mecanismo (Carmona, 1992). Segundo Silvertown (1984) a maioria das espécies daninhas produz sementes polimórficas, das quais uma grande parte se encontra dormente.

Diversos tipos de dormência são descritos, sendo que a maioria das espécies daninhas apresentam um ou mais tipos (Nikolaeva, 1977), bem como diferentes termos são utilizados para defini-las. Geralmente o termo dormência primária é utilizado para o tipo que ocorre durante a formação e maturação da semente e, dormência secundária para aquela induzida por fatores naturais ou 
artificiais, após disseminação da mesma (Chadoeuf-Hannel, 1985). Carmona (1992) acrescenta a estes, o termo dormência forçada, que é usado para definir a incapacidade das sementes germinarem em virtude de uma restrição ambiental como escassez de água, temperatura baixa e aeração pobre.

A dormência secundária é algumas vezes considerada como dormência induzida, no entanto Karssen (1982) ressalta que a dormência primária também pode ser induzida pelas condições ambientais durante a sua maturação na planta-mãe. A incapacidade de germinar já adquirida antes da disseminação da semente, pode residir dentro do próprio embrião ou devido a presença de um envoltório que cobre o embrião e o impede de germinar. As sementes de Avena fatua por exemplo, apresentam uma cobertura que é a principal barreira às trocas gasosas (Hsiao \& Quick, 1984).

Segundo Bewley \& Black ${ }^{1}$ citados por Chadoeuf-Hannel (1985) a dormência pode ser causada por barreiras a penetração de água e/ou a expansão do embrião, trocas gasosas ou alguma forma de inibição metabólica ou química no embrião ou tecidos de reserva. Baskin \& Baskin (1989) diferenciam a dormência de acordo com a permeabilidade ou impermeabilidade das sementes à água, desenvolvimento do embrião ou presença ou não de dormência fisiológica no embrião.

As plantas daninhas acumulam nos solos agrícolas grandes quantidades de sementes de idade e de potencial germinativos diferentes, por muitos anos, levando a uma grande heterogeneidade nos estados de dormência. Nas plantas anuais, poucas sementes germinam após o período de disseminação e sua aptidão para germinar posteriormente aparece como caráter cíclico.

Verdadeiramente, a maioria das sementes que permanecem no solo, passam periodicamente de um estado dormente a um não dormente, ou ao

'BEWLEY, J.D.; BLACK, M. Physiology and biochemistry of seeds in relation to germination. Viability, dormancy and environmental control. Springer Verlag Berlin, 1982, v. 2. 547 p. 
contrário (Chadoeuf-Hannel, 1985) e isso é devido às condições de micro e macro-ambiente, que criaria esses ciclos (Baskin \& Baskin, 1989).

Devido a esse caráter cíclico da dormência em sementes enterradas no solo, Karssen (1982) sugere que tanto a dormência primária como a secundária, é suprimida nas mesmas épocas do ano e pelos mesmos fatores ambientais.

Para Chadoeuf-Hannel (1985) em condições naturais a dormência da maiorias das sementes das espécies anuais é rompida principalmente pelos seguintes fatores: luz, alternância de temperatura e presença de íns nitrato; a composição dos gases ou o conteúdo de água no solo podem também influenciar na quebra da dormência.

Diferentes trabalhos foram realizados no intuito de obter a quebra da dormência de sementes, utilizando-se para isto alternância de temperatura (Steinbauer \& Grigsby, 1957; Harris et al., 1998), efeito da luz (Wesson \& Wareing, 1969; Gallagher \& Cardina, 1998), de substâncias promotoras de germinação (Hendricks \& Taylorson, 1974; Hsiao \& Quick, 1984; Egley, 1984; Cairns \& De Villiers, 1986; Agenbag \& De Villiers, 1989) e interação entre luz, temperatura, escarificação mecânica e substâncias promotoras (Vicent \& Roberts, 1977; Fellipe \& Polo, 1983; Ocampo Ruiz et al., 1990; Carmona \& Murdoch, 1996).

Para Hill (1977) muitas plantas daninhas possuem sementes pequenas que necessitam de luz para germinar, sendo consideradas como fotoblásticas positivas. Fellipe \& Polo (1983) encontraram que sementes de Sida cordifolia, S. rhombifolia e $S$. spinosa, comportam-se como fotoblásticas positivas. Amaranthus deflexus e Cassia patellaria foram fotoblásticas positivas quando estavam intactas e após escarificação passaram a ser indiferente à luz.

Quanto a escarificação, Ocampo Ruiz et al. (1990) obtiveram uma alta percentagem de germinação de sementes de Bidens pilosa somente quando elas foram colocadas para germinar em temperatura ao redor de $20^{\circ} \mathrm{C}$. 
O uso de compostos químicos como nitrato de potássio e giberelinas é cada vez mais evidente para superação de dormência de sementes. Para LeBaron (1991) tanto o nitrato de potássio como adubos nitrogenados, azidas e etileno estão sendo utilizados no campo, para estimular a germinação de sementes presentes no banco do solo, mas os resultados obtidos ainda não são satisfatórios. Carmona e Murdoch (1996) acreditam que a eficiência dessas substâncias depende de interações com tratamentos térmicos, os quais podem atenuar a dormência, tal como acontece para $A$. fatua em baixa temperatura e temperaturas alternadas para Chenopodium album.

A dormência é a principal causa da sobrevivência das sementes de plantas daninhas no solo, provocando infestações prolongadas nas áreas cultivadas (Chadoeuf-Hannel, 1985), distribuindo a germinação ao longo do tempo.

Segundo Freitas (1990) a variabilidade da germinação devido aos diferentes estados de dormência das sementes que permanecem na superfície ou enterradas no solo, dificulta a previsão das infestações das culturas. Portanto, torna-se indispensável um melhor conhecimento dos processos responsáveis pela germinação de sementes de espécies invasoras.

\subsection{Características do Banco de Sementes}

A germinação da semente é bastante variável ao longo do tempo. A presença de mecanismos de dormência intrínsecos, respostas diferentes de sementes quiescentes a fatores climáticos como temperatura, umidade e luminosidade, características do solo e o seu manejo, governam essa distribuição.

Para Carmona (1992) os fluxos de emergência de plântulas tendem a ocorrer em determinados períodos do ano. Estes fluxos são resultantes de condições ambientais favoráveis e da habilidade da semente viável responder a estes estímulos. 
Segundo Pierce \& Cowling (1991), a idade das sementes constituintes da banco é variável em função das espécies envolvidas e das condições do solo. O banco é composto por uma mistura de sementes de idades diferentes, acumuladas por vários anos, indicando as espécies que estiveram presentes no passado e que afetam a composição populacional das espécies do presente (Grime, 1989). O mesmo autor ressalta que há espécies que produzem grandes quantidades de sementes, sendo algumas capazes de permanecer viáveis, por longos períodos. Entretanto, há espécies em que a germinação ocorre em um curto espaço de tempo ou conservam a viabilidade por um curto período; estas espécies podem não estar presentes no banco ou ocorrer numa limitada camada do solo próxima à superfície (Coffin \& Lauenroth, 1989).

De acordo com o seu padrão de germinação de sementes e estabelecimento de plântulas, Thompson \& Grime (1979) classificaram os bancos de sementes em transitórios e persistentes. No banco transitório a germinação ocorre dentro de um ano após a dispersão, enquanto que no persistente a germinação excede esse período.

As espécies que apresentam banco transitórios não acumulam sementes no solo, sendo raras, as espécies de plantas daninhas que fazem parte desse tipo de banco, dentre elas são citadas Avena fatua, Alopecurus myosuroides e Matricaria perflorata (Barralis et al.,1988). As espécies que formam o banco transitório, estão adaptadas a explorar o espaço deixado por danos e morte da vegetação (Martins \& Silva, 1994).

O banco de sementes persistentes inclui todas as espécies cujas sementes podem persistir no solo por mais de um ano, sendo portanto, um parâmetro pouco sensível como instrumento de análise de sua dinâmica (Thompson, 1992). O mesmo autor ressalta, que na tentativa de aperfeiçoar estes parâmetros, foi sugerido o termo banco de sementes de curto prazo, cujo papel estaria na manutenção de populações, e banco de sementes de longo 
prazo, cujo papel estaria na regeneração de populações, após a sua extinção de áreas em que estivesse estabelecida há muitos anos.

O componente persistente do banco de sementes no solo representa uma reserva de material genético acumulado com o tempo (Simpson et al., 1989), fornecendo informações para estudos de evolução (Baker, 1989).

Há indicações de que a presença de bancos persistentes está associada a existência de sementes compactas, pequenas, lisas, que possuem mecanismos precisos de estimulação da germinação (Thompson, 1987).

As sementes do banco persistente geralmente encontram-se distribuídas no perfil do solo, sendo que, (Barralis et al., 1988) citam como exemplos de banco persistente as espécies: Chenopodium album, Sinapsis arvensis, Viola arvensis, Capsella bursa pastoris, Amaranthus retroflexus, Esta reserva de sementes constitui a origem do ciclo da vida das espécies anuais, sendo a causa fundamental da sua persistência Euphorbia exigua.

Segundo Rouw \& Oers (1988) é preferivel a presença de espécies persistentes nos bancos de habitats constantemente modificados das áreas cultivadas. A sobrevivência por longo prazo de suas populações depende, freqüentemente, da habilidade das sementes permanecerem dormentes durante os períodos nos quais o habitat fica ocupado pelas plantas cultivadas.

A elevada capacidade reprodutiva e longevidade, associada com mecanismos de dormência, leva ao acúmulo de sementes nos solos agrícolas, formando o banco de sementes. A manutenção do banco está diretamente relacionada com a presença de sementes dormentes; em ecossistemas agrícolas a dormência tem papel fundamental, pois garante infestações futuras.

Ela também pode garantir a sobrevivência de espécies na forma de semente, sob condições adversas, mesmo quando a vegetação é completamente eliminada (Carmona, 1992).

Nos solos agrícolas, as sementes de plantas daninhas anuais são as principais constituintes do banco, alcançando $95 \%$ do total, sendo que as perenes encontram-se pouco representadas (Barralis et al., 1988). 


\subsection{Dinâmica do banco de sementes}

Os estudos de dinâmica de populações tem por objetivo determinar o tamanho e a composição das populações presentes no banco de sementes ao longo do tempo, e os fatores que influem no seu tamanho bem como nas espécies presentes.

A dinâmica de um banco de sementes está na sucessão de eventos de entrada ou saida de sementes do banco em relação ao tempo (Simpson et al., 1989). A entrada de sementes pode ocorrer através de diversas formas, como, dispersão da própria semente por vento, água, animais e esterco, por sementes da cultura contaminada, implementos agrícolas, etc.

As sementes produzidas no próprio campo, são a principal fonte de incremento do banco (Cavers, 1983). No entanto, o vento, água, implementos e outros, podem ser importantes meios de introdução e estabelecimento de novas espécies.

As plantas daninhas possuem a característica de produzir uma grande quantidade de sementes (Cousens \& Mortimer, 1995); porém em ambiente agricola elas tendem a produzir menos sementes devido à competição com a cultura, danos por herbicidas e outros.

As sementes de plantas daninhas possuem um potencial para sobreviver por muito tempo no banco de sementes, porém muitas apresentam vida curta. Os fatores que acarretam as perdas de sementes do solo incluem-se a germinação, predação, apodrecimento e movimento físico (Murdoch \& Ellis, 1992).

As perdas de sementes de um banco resultam de respostas fisiológicas ao ambiente quando geneticamente controladas, como à luz, temperatura, tensão de oxigênio e estímulos químicos, tendo como conseqüência a germinação; enterrio profundo ou redispersão das sementes, interação do banco com animais e patógenos, levando a semente à morte (Carvalho \& Favoretto, 1995). 
A dinâmica de entrada e saída de sementes do banco de sementes determina em que densidade encontraremos uma espécie em uma comunidade, tanto a nível de reservas de sementes, quanto na participação como indivíduo, mesmo que a correlação entre banco de sementes e a proporção de indivíduo encontrado na comunidade seja, na maioria das vezes, baixa (Rice, 1989).

De acordo com Voll et al. (1996) a sobrevivência de plantas daninhas é função da intensidade da germinação, da emergência e da morte das espécies na sua interação com o ambiente.

O tamanho, composição do banco de sementes e a vegetação presente na superfície do solo, reflete todo o sistema de manejo de solo e plantas daninhas que foi realizado. Em áreas cultivadas, a redução do tamanho do banco de sementes através das estratégias de manejo, tem sido a principal meta.

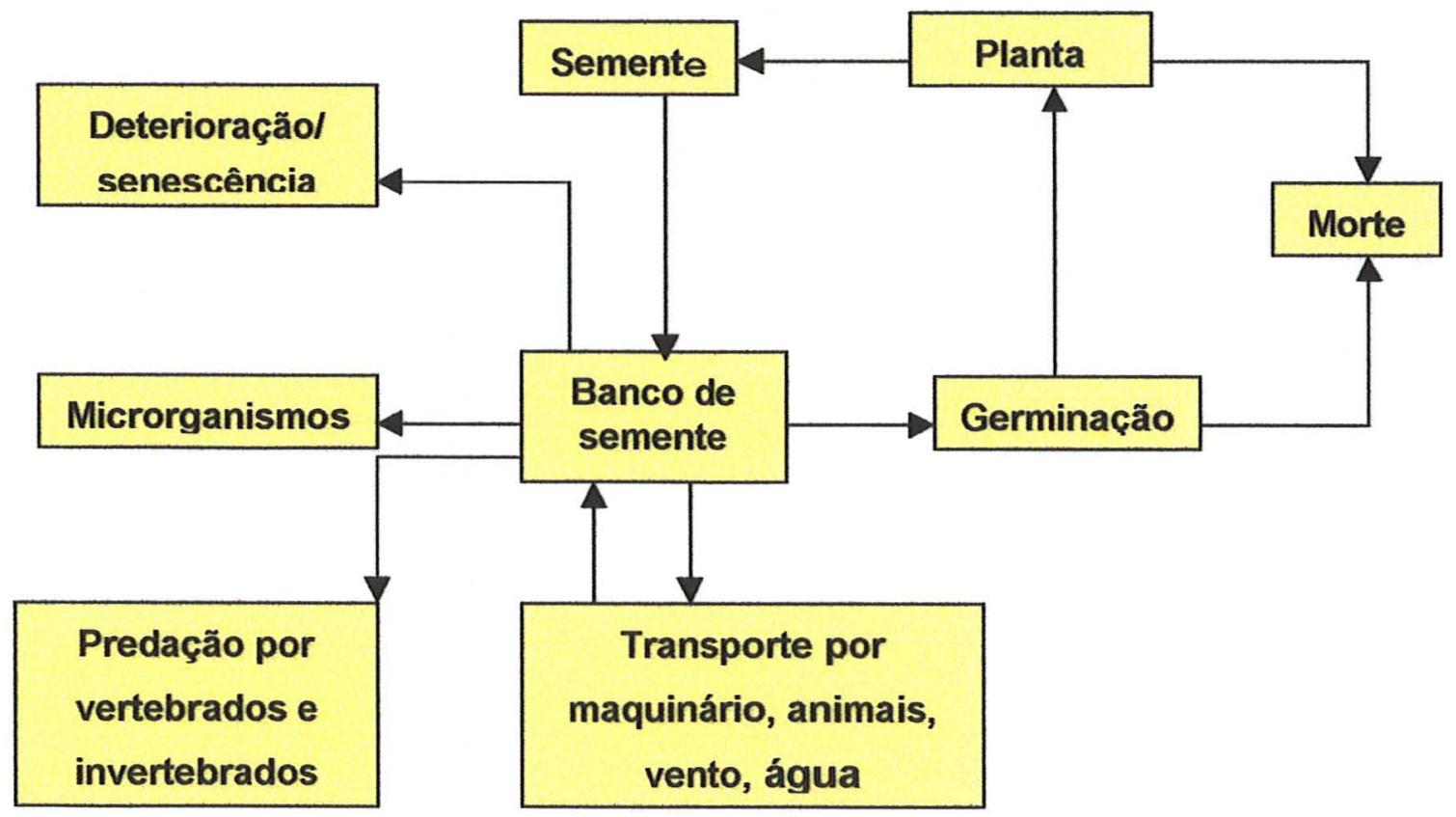

Figura 1. Dinâmica de bancos de sementes no solo.

Fonte: Carmona (1992) 


\subsection{Efeito de práticas culturais sobre o banco de sementes}

Os agroecossistemas são caracterizados por ambientes altamente perturbados, sendo que as espécies que habitam esses locais são adaptadas a responder a este regime de distúrbio (Young \& Evans, 1976). Modificaçōes nas práticas de manejo alteram os padrōes de distúrbio e produz mudanças na comunidade daninha ao longo do tempo.

As práticas de preparo de solo são realizadas com diversos objetivos, dentre eles destacam-se a retirada de plantas indesejáveis e o rompimento de camadas endurecidas de solo, aumentando assim sua aeração. No entanto, o revolvimento do solo estimula a germinação das sementes devido a uma maior exposição dessas à luz, alternância de temperatura e umidade. Por outro lado, o efeito das práticas de preparo do solo sobre a quebra de dormência das sementes é função da distribuição vertical das sementes ao longo do perfil antes e após o cultivo (Cavers \& Benoit, 1989).

Os sistemas de preparo do solo afetam o manejo das plantas daninhas bem como a sua produção de sementes e o distúrbio causado por essas práticas influenciam a densidade e distribuição vertical das sementes da comunidade daninha no solo (Buhler, 1995). O preparo do solo é a causa primária do movimento vertical das sementes ao longo do perfil do solo (Cousens \& Moss, 1990). Para Dessaint et al., 1990 o manejo do solo na mesma profundidade favorece a distribuição uniforme das sementes ao longo do perfil trabalhado, encontrando-se menores populações em maiores profundidades.

A utilização de técnicas que promovam a inversão das camadas de solo como a aração, resulta no enterrio de grande quantidade de sementes; já os métodos que não promovam a inversão de camadas, permite que a maioria das sementes permaneçam próximo à superfície do solo. Essa proximidade da superfície do solo, proporciona maior germinação das sementes e 
estabelecimento de plantas daninhas, quando comparado com outros métodos (Ball, 1992).

Staricka et al., (1990) avaliaram os efeitos do arado de aiveca e escarificador sobre a distribuição vertical das sementes de plantas daninhas no solo, usando esferas de cerâmica com tamanho e densidade similar ao das sementes. Foram encontradas esferas na profundidade de 12 centimetros quando usou-se escarificador e a $32 \mathrm{~cm}$ para arado de aiveca. Nas parcelas escarificadas, $48 \%$ das esferas encontravam-se a $4 \mathrm{~cm}$ da superfície do solo e somente $4 \%$ para arado de aiveca.

Ball (1992) comparando as formas de preparo de solo, arado de disco e grade, observou predominância de sementes de plantas daninhas mais próximas a superfície após a utilização de grade.

Após cinco anos de trabalho, Yenish et al., (1992) encontraram menor número de sementes nas parcelas onde foi utilizado arado de aiveca em comparação com aquelas escarificadas e onde não houve tratamento de preparo de solo. Nas parcelas não trabalhadas, encontrou-se mais de $60 \%$ de todas as sementes de plantas daninhas na camada de $0-1 \mathrm{~cm}$ do solo. A concentração das sementes nessas parcelas decresceu de forma logaritma com o aumento da profundidade.

Clements et al. (1996) estudaram a influência do tipo de preparo de solo sobre o banco de sementes e encontraram mais de $70 \%$ das sementes na camada de 0-5 cm, para parcelas sem preparo, e 33\% para áreas escarificadas. Estes resultados são concordantes com os encontrados por Cardina \& Sparrow (1996).

Algumas espécies daninhas podem apresentar-se com maior intensidade de emergência no sistema de semeadura direta do que no convencional. Carmona (1992) ressalta que o plantio direto e o cultivo superficial tendem a acelerar o decréscimo de sementes récem-derrubadas no solo por indução de germinação ou perda de viabilidade. A presença de sementes na camada mais superficial e o freqüente cultivo, predispõem a um 
esgotamento do banco mais rapidamente. Essas situações, facilitam a predação, expõem as sementes a amplas variações de temperatura e umidade, auxiliando na quebra da dormência. Porém, a velocidade do esgotamento depende da produção de sementes das espécies presentes (FernándezQuintanilla, 1988; Yenish et al., 1992).

Para as sementes encontradas abaixo do perfil de cultivo, onde as condições são mais uniformes, a ação dos fatores externos é menor, e assim elas mantêm-se viáveis por mais tempo. Para Roberts \& Dawkins (1967) a manutenção da viabilidade dependerá da espécie e características das sementes.

A rotação de culturas é uma prática efetiva no manejo das plantas daninhas, visto que produz uma diversificação na pressão de seleção, modificando os padrões de distúrbios. Segundo Liebman \& Dick ${ }^{2}$ citados por Buhler et al. (1997) esta diversificação previne a proliferação de espécies adaptadas com práticas associadas a uma única cultura, tal como acontece em sistemas de monocultura.

Os trabalhos de Forcella \& Lindstron (1988), Ball \& Miller (1990), e Schreiber (1992) encontraram menor quantidade de sementes em sistema de rotação quando comparado com monocultivo. O mecanismo pelo qual a rotação de culturas reduz o tamanho do banco está relacionado com a seqüência de culturas empregando-se diferentes modelos de competição de recursos, interferências alelopáticas, distúrbios do solo e diversas estratégias de manejo de plantas daninhas (Buhler et al., 1997).

A utilização de herbicidas também influencia as espécies que compõem o banco de sementes, podendo reduzir drasticamente a população de sementes de plantas daninhas no solo (Roberts \& Neilson, 1981).

O número de sementes do banco de sementes de um solo cultivado continuamente com milho foi reduzido em aproximadamente $70 \%$, após três

\footnotetext{
${ }^{2}$ LIEBMAN, M.; DYCK, E. Crop rotation and intercropping strategies for weed management. Ecol. Applic. v.3, p. 92-122, 1993.
} 
anos com aplicação de atrazina e cultivo nas entrelinhas. Quando substituiu-se o herbicida por cultivos, o número de sementes aumentou cerca de 25 vezes mais em comparação as parcelas com herbicida (Schweizer \& Zimdahl, 1984). O uso contínuo de triazinas nessa cultura no Canadá alterou a composição da flora daninha, e resultou num aumento de plantas resistentes a esse produto (Cavers \& Benoit, 1989).

Dentro das áreas agrícolas, onde o solo é freqüentemente perturbado, o banco de sementes atua como estabilizador, assegurando a sobrevivência das espécies (Roberts, 1981).

O desenvolvimento de sistemas de manejo integrado de plantas daninhas é uma tarefa complexa, podendo ser mais eficiente se houver um completo entendimento da dinâmica populacional das plantas daninhas. Cada população é composta por individuos em diferentes estágios funcionais, os quais interagem com outros indivíduos da mesma população ou não, e com o ambiente (Fernández-Quintanilla, 1988).

As plantas daninhas são altamente adaptativas, devido a diversidade genética e habilidade para adaptar-se a condições desfavoráveis criadas pelos diferentes sistemas de cultivo. O conhecimento da dinâmica de populações de plantas daninhas poderá ser útil na identificação de estágios vulneráveis no ciclo de vida dessas plantas, que podem ser explorados nos sistemas de manejo. Pode-se também identificar as espécies que são favorecidas com as práticas de manejo e desenvolver um sistema de manejo apropriado para as plantas daninhas alvo.

\subsection{Controle de plantas daninhas em citros}

As culturas agrícolas estão sujeitas a uma série de fatores do ambiente que direta ou indiretamente influenciam o seu crescimento, desenvolvimento e produtividade econômica. Esses também denominados de ecológicos, podem ser de natureza biótica ou abiótica. Dentre fatores bióticos incluem-se as plantas daninhas. 
Uma planta é considerada como daninha, quando ela está presente em local onde ela não é indesejável (Pitelli, 1980) causando transtornos à atividade agrícola e prejudicando o desenvolvimento e rendimento econômico da planta cultivada. No entanto, a competição somente se estabelece quando a intensidade de recrutamento dos recursos do meio pelos competidores é maior do que a capacidade do meio em fornecer os recursos, ou quando um indivíduo impede o outro de ter acesso a esses recursos.

As plantas daninhas podem competir com as plantas cultivadas por nutrientes, água, luz e espaço, hospedar insetos, nematóides e outros organismos prejudiciais a estas plantas, bem como dificultar a adoção das práticas culturais e interferindo na qualidade do produto final (Gelmini, 1995).

A comunidade infestante é responsável por muitas perdas na produtividade das culturas. Em um pomar de citros, De Negri (1996) encontrou perdas ao redor de 5\% ao ano; porém, Durigan (1996) relata que em pomares onde não foi realizado manejo adequado das plantas daninhas, as perdas variaram de 20 a $40 \%$.

Antes de se determinar qual o método de controle a ser utilizado, é necessário determinar o período no qual esse controle vai ser realizado, porque - controle tem que ser eficiente e economicamente viável. Deve-se conhecer um pouco sobre as espécies presentes, os seus fluxos de emergência, bem como saber se as plantas presentes estão em competição.

Alguns trabalhos foram realizados com o intuito de definir a melhor época para o controle das plantas daninhas. Rodriguez (1957) relatou a necessidade de fazer o controle na época das secas, para se minimizar a competição por água; esse resultado foi confirmado por De Negri (1996).

No entanto, Galli \& Carvalho (1985) ressaltam que na estação das chuvas, possivelmente por influência das condições climáticas, as plantas daninhas apresentavam maior agressividade vegetativa e reprodutiva. Nesse período, sugere-se que as entrelinhas da cultura sejam mantidas com alguma vegetação intercalar, sendo que as plantas daninhas não devam ultrapassar a 
altura de $10 \mathrm{~cm}$. Esta faixa com planta daninha protege o solo da erosão e serve como fonte de matéria orgânica. Porém, próximo à planta o controle deve ser feito durante todo 0 ano, pois nessa área concentra-se a maioria das radicelas que são responsáveis pela absorção de nutrientes.

Blanco \& Oliveira (1978) em trabalho realizado na região de Limeira/SP, observaram que o controle efetuado no período de agosto a novembro ou dezembro a março, proporcionaram produções semelhantes àquelas onde o pomar havia sido mantido no limpo durante todo o ano. Porém, Carvalho et al. (1993) em Rio Real/Ba, observaram que quando o pomar foi mantido limpo durante o período de setembro/outubro e de abril/maio, foram alcançadas maiores produções.

\subsubsection{Métodos de controle}

O manejo das plantas daninhas nos pomares de citrus é bastante diversificado, empregando-se o controle mecânico - capina manual com enxada e capina mecânica com equipamentos que produz revolvimento do solo como, grade-de-discos, enxada-rotativa ou arado - cobertura vegetal (morta ou viva) e controle químico (Petto Neto, 1991).

\subsubsection{Controle mecânico}

A capina manual é um método de controle de plantas daninhas que somente justifica sua utilização ao redor das plantas (coroas) ou em faixas laterais; também em determinadas situações, como áreas declivosas e quando têm-se mão-de-obra suficiente. Atualmente esse método está sendo substituído pela capina química, em virtude de danos que possa ocorrer no sistema radicular das plantas e por fatores de ordem econômica (Petto Neto, 1991). O controle mecânico realizado com grades e enxadas rotativas é normalmente direcionado ao controle das plantas daninhas na entrelinha de plantio. Esses implementos, além de controlar as plantas infestantes auxiliam na incorporação 
de calcários e adubos, estimula o crescimento das radicelas, não necessitando de mão-de-obra muito especializada, sendo um método econômico. Porém, o seu efeito não é duradouro e a possibilidade de disseminação de espécies que se propagam vegetativamente aumenta; devido ao corte de radicelas, a possibilidade de infeção por Phytophthora ou outros organismos é maior e consequentemente a transmissão de gomose e virose também cresce. Podem causar compactação do solo, erosão laminar e lixiviação de nutrientes, além de reduzir o teor de matéria orgânica e desestruturação física do solo (Coopercitrus, 1990).

\subsubsection{Controle químico}

Os estudos de utilização de herbicidas para o controle de plantas daninhas em pomares cítricos foram iniciados na década de 50. A partir daí, houve uma evolução muito grande na sua utilização nas diversas regiões de todo o mundo. No Brasil, houve um incremento na utilização do controle químico principalmente pela escassez de mão-de-obra e a maior eficiência dos herbicidas em relação aos métodos tradicionais.

A utilização de herbicidas para controle da comunidade infestante apresenta diversas vantagens como: controle rápido e eficiente sem causar injúrias no tronco e nas radicelas, diminuindo a propensão à incidência e transmissão de gomose e leprose; controla espécies hospedeiras de insetos vetores de doenças, como as do gênero Brachiaria onde várias espécies de cigarrinha podem transmitir a bactéria Xilella fastidiosa causadora do CVC; controla plantas daninhas antes e depois de germinadas; controla mais facilmente plantas daninhas perenes; reduz o número de tratos culturais e facilita a colheita (Petto Neto, 1991; Victoria Filho et al., 1991).

No entanto, Gelmini (1988) ressalta que alguns fatores podem limitar a eficiência do produto, impedindo que os resultados sejam satisfatórios. Entre estes incluem-se a escolha errada do produto em função de condições 
ambientais, erro de dosagem e de calibragem, falha no ajuste do equipamento de aplicação ou a aplicação em épocas inadequadas. Pode-se acrescentar o fato de que os herbicidas possuem limitações inerentes às próprias características, sendo necessário conhecê-las para maximizar a sua potencialidade.

No mercado há diversos produtos disponiveis para o controle de plantas daninhas em citros, sendo pertencentes por exemplo aos grupos dos arseniacais orgânico, bipiridilios, derivados de aminoácido, da uréia, do éter bifenílico, dinitroanilinas, oxazolidinas, propianamidas, triazinas e uracilas, podendo ser utilizados em tratamentos de pré-plantio incorporado, pré e pósemergência (Gelmini, 1991, Victoria Filho et al., 1991).

Em nosso de estudo, os herbicidas aplicados foram o diuron e 0 glyphosate. $O$ diuron (3-(3,4-diclorofenil)-1,1-dimetiluréia), é um produto derivado da uréia, sendo registrado para o controle de mono e dicotiledôneas em culturas anuais, perenes, áreas não cultivadas e canais de irrigação e drenagem. É utilizado preferencialmente em pré-emergência, por ser a via radicular mais importante de absorção, podendo ser também usado em pósemergência precoce das plantas daninhas. O glyphosate ( $\mathrm{N}$-(fosfonometil) glicina), é um derivado da glicina, indicado para o controle não seletivo de mono e dicotiledôneas em pós-emergência nas diversas culturas (Rodrigues \& Almeida, 1998).

Misturas de herbicidas são também utilizadas no controle da comunidade daninha em pomar de citros, como relatam os trabalhos de Galli \& Carvalho, 1985; Marcondes et al., 1985; Durigan et al., 1988; Carvalho et al., 1990.

\subsubsection{Cobertura vegetal}

A utilização de métodos mecânicos principalmente gradagem, no controle das plantas daninhas proporciona modificações na estrutura física do 
solo, como tamanho e percentagem de agregados (Cintra \& Coelho, 1983). Isto é mais agravante nos solos denominados 'tabuleiros', os quais são caracterizados por baixa capacidade de retenção de água e pelo adensamento que ocorre nas profundidades de $15-20$ e $70-80 \mathrm{~cm}$.

Nos Estados da Bahia e de Sergipe, a citricultura está implantada sobre este tipo de solo. O manejo de plantas daninhas adotado consiste de capinas manuais nas linhas e gradagem nas entre linhas, aumentando mais os problemas de solo e consequentemente sendo pouco produtivo (Vitti, 1992).

A cobertura vegetal com leguminosas, além de produzir melhorias nas características físicas e químicas do solo, também é utilizada como um método de controle das plantas daninhas (Victoria Filho \& Christoffoleti, 1997).

As plantas pertencentes a essa familia tem a capacidade de fixar por simbiose o nitrogênio atmosférico, e incorporá-lo ao solo através das suas raízes, sendo considerados como adubos verdes.

Cintra \& Coelho, (1983) observaram que a presença de vegetação nas entre linhas de plantio proporcionou a manutenção das características físicas do solo, redução da densidade na camada próxima à superfície, devido ao aumento no teor de matéria orgânica.

Muitas são as espécies que podem ser utilizadas como cobertura em pomares cítricos, entretanto, não há uma definição em relação a incorporação ou não da matéria verde. Dentre as principais leguminosas destacam-se o feijão de porco (Canavalia sp.), mucuna-preta (Stilozobium atterimum), crotalária (Crotalaria juncea), guandu (Cajanus cajan), lab-lab (Dolichos lab-lab), dentre outras (Caetano, 1980).

No entanto, a utilização de leguminosas anuais de hábito trepador, como o lab-lab e a mucuna-preta devem ter o crescimento vegetativo controlado, para não prejudicarem as plantas citricas. $O$ plantio de leguminosas de porte alto como a crotalária e o guandu devem ser evitados em pomares adultos, visto que competem com as plantas pela luz (Petto Neto, 1991). 
É necessário salientar também que existem fatores limitantes para a implantação e desenvolvimento de leguminosas, sendo temperatura, disponibilidade de água e solo. Quanto a temperatura deve-se escolher a espécie mais adaptada à época de plantio, tendo-se as denominadas de 'verão' $e$ as de 'inverno'. Mucuna-preta e lab-lab são mais sensiveis ao frio do que crotalária e guandu. Para solo não há muita especificidade, devendo-se ter um mínimo de fertilidade em relação a cálcio, magnésio, fósforo e potássio. O fator água define um maior ou menor desenvolvimento da planta. Deve-se ter uma boa disponibilidade de água para que não ocorra competição entre a leguminosas e a cultura (Bulisani et al., 1987). 


\section{MATERIAL E MÉTODOS}

\subsection{Localização do pomar}

O pomar foi implantado em área experimental do Departamento de Produção Vegetal da Escola Superior de Agricultura "Luiz de Queiroz"/USP, localizada em Piracicaba/São Paulo. $O$ município apresenta as seguintes coordenadas geográficas: altitude de $560 \mathrm{~m}$, latitude de $22^{\circ} 45^{\prime} \mathrm{S}$ e longitude de $47^{\circ} 38^{\prime} \mathrm{W}$. O clima da região é do tipo $\mathrm{Cwa}$, segundo a classificação de Koeppen, ou seja, trata-se de clima mesotérmico, úmido tropical com inverno seco.

Os dados referentes a precipitação $(\mathrm{mm})$, umidade relativa $(\%)$ e temperaturas mínima, máxima e média $\left({ }^{\circ} \mathrm{C}\right)$ durante a condução do experimento, são encontrados na Tabela 1.

O solo da área experimental foi classificado por Vidal-Torrado \& Sparovek (1993) como sendo Podzólico Vermelho-Amarelo Distrófico, Tb, A moderado com textura média/média. Nas Tabelas 2 e 3 estão apresentados os resultados da análise química e granulométrica do solo, respectivamente.

Anteriormente, essa área era cultivada com citros, sendo depois explorada por quatro anos com o cultivo da cana-de-açúcar, no qual utilizou-se o controle químico como manejo de plantas daninhas.

\subsection{Plantio, variedade e tratos culturais}

A implantação do pomar foi realizada em março de 1995 e, devido a um grande ataque da doença cítrica leprose, fez-se o replantio das mudas 
Tabela 1. Precipitação $(\mathrm{mm})$, umidade relativa (\%), temperatura máxima, mínima e média $\left({ }^{\circ} \mathrm{C}\right)$ de Piracicaba/SP, nos anos de 1997 e 1998.

\begin{tabular}{|c|c|c|c|c|c|c|}
\hline $\begin{array}{l}\text { Ano } \\
1997\end{array}$ & Mês & $\begin{array}{l}\text { Precipitação } \\
(\mathrm{mm})\end{array}$ & $\begin{array}{l}\text { U. Relativa } \\
(\%)\end{array}$ & $\begin{array}{l}\text { Temperatura } \\
\text { Máxima }{ }^{\circ} \mathrm{C}\end{array}$ & $\begin{array}{l}\text { Temperatura } \\
\text { Mínima }{ }^{\circ} \mathrm{C}\end{array}$ & $\begin{array}{l}\text { Temperatura } \\
\text { Média }{ }^{\circ} \mathrm{C}\end{array}$ \\
\hline & Janeiro & 352,2 & 86,9 & 29,7 & 20,1 & 24,9 \\
\hline & Fevereiro & 87,1 & 79,5 & 31,7 & 19,5 & 24,7 \\
\hline & Março & 73,1 & 73,3 & 29,9 & 17,5 & 23,7 \\
\hline & Abril & 22,0 & 73,2 & 28,7 & 15,0 & 21,9 \\
\hline & Maio & 55,0 & 78,3 & 25,7 & 12,6 & 19,2 \\
\hline & Junho & 124,5 & 84,2 & 23,5 & 11,4 & 17,4 \\
\hline & Julho & 15,4 & 77,3 & 26,1 & 11,3 & 18,7 \\
\hline & Agosto & 15,9 & 71,0 & 27,8 & 11,2 & 19,5 \\
\hline & Setembro & 95,0 & 71,4 & 29,4 & 15,3 & 22,4 \\
\hline & Outubro & 62,8 & 76,6 & 29,4 & 17,3 & 23,3 \\
\hline & Novembro & 269,4 & 81,6 & 30,3 & 19,5 & 25,0 \\
\hline & Dezembro & 186,7 & 78,0 & 31,1 & 19,7 & 25,4 \\
\hline $\begin{array}{l}\text { Ano } \\
1998\end{array}$ & Mês & $\begin{array}{c}\text { Precipitação } \\
(\mathrm{mm})\end{array}$ & $\begin{array}{l}\text { U. Relativa } \\
(\%)\end{array}$ & $\begin{array}{l}\text { Temperatura } \\
\text { Máxima }{ }^{\circ} \mathrm{C} \\
\end{array}$ & $\begin{array}{c}\text { Temperatura } \\
\text { Minima }{ }^{\circ} \mathrm{C} \\
\end{array}$ & $\begin{array}{c}\text { Temperatura } \\
\text { Média }{ }^{\circ} \mathrm{C} \\
\end{array}$ \\
\hline & Janeiro & 121,2 & 79,0 & 32,0 & 21,0 & 26,2 \\
\hline & Fevereiro & 362,2 & 90,0 & 30,0 & 20,5 & 25,2 \\
\hline & Março & 127,8 & 85,0 & 31,0 & 20,0 & 25,4 \\
\hline & Abril & 66,7 & 81,0 & 28,4 & 17,0 & 23,0 \\
\hline & Maio & 97,6 & 81,0 & 25,0 & 13,0 & 19,0 \\
\hline & Junho & 26,6 & 87,0 & 24,1 & 10,0 & 17,0 \\
\hline & Julho & 13,9 & 81,0 & 26,0 & 11,0 & 18,4 \\
\hline & Agosto & 21,8 & 77,0 & 27,4 & 14,4 & 20,9 \\
\hline & Setembro & 89,3 & 76,0 & 28,0 & 15,3 & 21,5 \\
\hline & Outubro & 183,1 & 83,0 & 27,1 & 16,3 & 22,0 \\
\hline & Novembro & 26,6 & 77,0 & 30,0 & 16,4 & 23,2 \\
\hline & Dezembro & 292,6 & 82,0 & 30,0 & 19,2 & 24,6 \\
\hline
\end{tabular}

Fonte: Departamento de Física e Meteorologia da Esalq/USP. 
Tabela 2. Análise química do solo para a entrelinha e linha de plantio em duas profundidades.

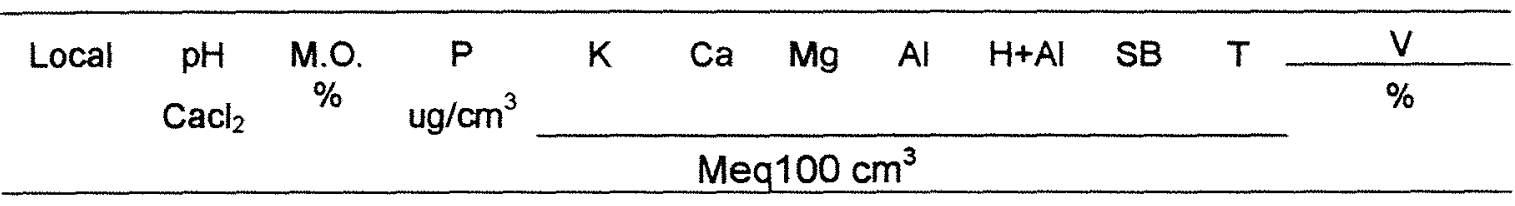

Entrelinha $(\mathrm{cm})$

$\begin{array}{lllllllllllll}0-10 & 4,7 & 2,0 & 6 & 0,21 & 1,3 & 0,6 & 0,3 & 2,8 & 2,1 & 4,9 & 43 & 13\end{array}$

$\begin{array}{lllllllllllll}10-20 & 4,2 & 1,7 & 3 & 0,06 & 0,8 & 0,3 & 0,9 & 3,4 & 1,2 & 4,6 & 28 & 43\end{array}$

Linha $(\mathrm{cm})$

$\begin{array}{lllllllllllll}0-10 & 4,8 & 1,3 & 7 & 0,27 & 1,5 & 0,8 & 0,1 & 2,5 & 2,6 & 5,1 & 51 & 4\end{array}$

$\begin{array}{lllllllllllll}10-20 & 4,5 & 0,7 & 3 & 0,16 & 1,0 & 0,5 & 0,4 & 2,8 & 1,7 & 4,5 & 38 & 19\end{array}$

infectadas em novembro do mesmo ano. O preparo da área para o plantio e os tratos culturais utilizados, foram de acordo com as recomendações para a cultura do citros; as adubações de plantio bem como as dos anos seguintes foram realizadas tendo-se como base a análise de solo da área.

O espaçamento de plantio utilizado foi de $7 \mathrm{~m} \times 3 \mathrm{~m}$, sendo cada unidade experimental formada por 3 linhas de plantio com 4 plantas cada. A variedade plantada foi a 'Pera' (Citrus sinensis (L.) Osbeck) enxertada sobre limão 'Cravo' (Citrus limonia (L.) Osbeck). Esta variedade é plantada em 52\% da área relativa às laranjas do Estado de São Paulo. É caracterizada por produzir frutos com bom rendimento de suco e teores médios de brix e acidez; os frutos se destinam ao consumo in natura para o mercado interno e de suco concentrado (Figueiredo, 1991). Fez-se todas as práticas culturais recomendadas para os citros, como controle fitossanitário, de saúvas e poda de ramos considerados ladrões. 
Tabela 3. Análise granulométrica do solo para a entrelinha e linha de plantio em duas profundidades.

\begin{tabular}{|c|c|c|c|c|c|c|}
\hline \multirow[b]{2}{*}{ Local } & Areia \% & \multirow[t]{2}{*}{ Silte\% } & \multirow{2}{*}{$\frac{\text { Argila \% }}{\text { Total }}$} & \multirow{2}{*}{$\begin{array}{r}\text { Classe de } \\
\text { Textura }\end{array}$} & D.A. & D.R. \\
\hline & Fina & & & & \multicolumn{2}{|c|}{$\mathrm{G} / \mathrm{cm}^{3}$} \\
\hline \multicolumn{7}{|c|}{ Entrelinha $(\mathrm{cm})$} \\
\hline $0-10$ & 72 & 10 & 18 & md-ar & 1,34 & 2,38 \\
\hline $10-20$ & 74 & 8 & 18 & md-ar & 1,60 & 2,35 \\
\hline \multicolumn{7}{|c|}{ Linha $(\mathrm{cm})$} \\
\hline $0-10$ & 74 & 8 & 18 & md-ar & 1,26 & 2,41 \\
\hline $10-20$ & 74 & 6 & 20 & md-ar & 1,52 & 2,35 \\
\hline
\end{tabular}

Classes de diâmetro $(\mathrm{mm})$ :

areia fina $=0,25-0,10$; silte $=0,05-0,002$; argila $<0,002$.

Classes de textura: de 15 a $24 \%$ - média-arenosa (md-ar).

D.A. $=$ Densidade aparente; $D . R .=$ Densidade real

\subsection{Tratamentos}

O experimento constou de tratamentos na linha e na entrelinha de plantio da cultura. Como tratamento na linha utilizou-se os herbicidas glyphosate ( $\mathrm{N}$-(fosfonometil) glicina) na dose de $1,08 \mathrm{Kg}$ i.a/ha em pósemergência, e diuron (3-(3,4-diclorofenil)-1,1-dimetiluréia) em pré-emergência na dose de 2,0 $\mathrm{Kg}$ i.a/ha. Esses herbicidas foram combinados com outros cinco métodos de manejo de plantas daninhas nas entrelinhas de plantio, tais como: a) roçagem da vegetação natural duas vezes no período chuvoso (outubro a março) e gradeação superficial uma vez no período seco (abril a setembro); b) dose reduzida $(0,540 \mathrm{Kg}$ i.a/ha.) do herbicida glyphosate duas vezes ao ano (abril e novembro); c) plantio do adubo verde guandu (Cajanus cajan), como cultura intercalar no período chuvoso; d) plantio do adubo verde lab-lab (Dolichos lablab) como cultura intercalar no período chuvoso; e) duas gradagens de disco, sendo uma no período chuvoso e outra no seco. Na Tabela 
4 são apresentadas as combinações de tratamentos obtidas, os quais foram repetidos no campo três vezes.

Tabela 4. Tratamentos utilizados na linha e entrelinha de plantio na cultura do citros.

Tratamento na linha

1. glyphosate em pós-emergência

2. diuron em pré-emergência
Tratamento na entrelinha

1. roçagem na época chuvosa e gradagem na seca

2. dose reduzida de glyphosate em abril e novembro

3. leguminosa guandu no período chuvoso

4. leguminosa lab-lab no período chuvoso

5. gradagem no periodo chuvoso e seco

\subsection{Amostragem do banco de sementes}

Antes da execução das operações que compõem os tratamentos anuais, foi realizado um levantamento da flora daninha e retirada amostra de solo em todas as parcelas a serem estudadas.

As amostras de solo foram obtidas das linhas e entrelinhas em área previamente demarcada; para as entrelinhas de cada parcela utilizou-se duas faixas de $21 \mathrm{~m}^{2}(6 \mathrm{~m} \times 3,5 \mathrm{~m})$ cada, onde retirou-se 45 amostras simples, abrangendo a área em forma de ' $W$ ', de acordo com Roberts (1981), para 
formar três sub-amostras compostas, nas profundidades de 0 a $10 \mathrm{~cm}$ e de 10 a $20 \mathrm{~cm}$.

Nas linhas de plantio, utilizou-se a faixa existente entre as plantas $(2 \mathrm{~m} \times 1 \mathrm{~m})$, de todas as linhas da parcela (no total de três), retirando-se de cada faixa cinco amostras simples, totalizando por parcela 45 amostras. O solo retirado na linha foi nas mesmas profundidades que o da entrelinha, e também formaram três sub-amostras compostas.

A definição do número de amostras a ser retirada de cada parcela foi baseada em resultados de uma análise preliminar da variância da quantidade de sementes presentes na amostra, visto que na literatura não há uma definição desse número e, segundo Benoit et al. (1989) a variância do número de sementes nas amostras tem correlação inversa com o número de amostras. Sendo assim, quanto maior o número de sementes na amostra, menor será a variância e consequentemente maior será o número de amostras necessárias para estimar o banco de sementes. Os dados referentes a esta análise preliminar se encontram na Tabela 5; procurou-se obter uma menor variância com um número de amostras que fosse satisfatório para a realização do experimento.

Para obter-se as amostras utilizou-se um trado de $4,3 \mathrm{~cm}$ de diâmetro, sendo que o peso médio de cada amostra foi em torno de $220 \mathrm{~g}$. As amostras de solo retiradas eram colocadas em baldes plásticos e ao final em sacolas plásticas, devidamente etiquetadas, formando amostras compostas e levadas ao laboratório para serem processadas. Após a retirada o material era limpo a fim de evitar contaminação da amostra seguinte. As amostragens foram retiradas em duas estações diferentes: no período chuvoso (novembro de 1997) e no período seco (julho de 1998). 
Tabela 5. Resultados da análise preliminar do número de amostragem e variância do número de sementes.

\begin{tabular}{ccc}
\hline Número de amostras & $\begin{array}{c}\text { Número médio de } \\
\text { sementes/amostra }\end{array}$ & Variância \\
\hline 5 & 13 & 14 \\
10 & 34 & 9 \\
15 & 46 & 6 \\
20 & 71 & 4 \\
25 & 86 & 2 \\
30 & 102 & 1 \\
35 & 110 & 1 \\
40 & 134 & 0,4 \\
45 & 162 & 0,02 \\
\hline
\end{tabular}

\subsection{Dinâmica do banco de sementes}

\subsubsection{Pela germinação em bandejas}

Para determinação do número de sementes viáveis retirou-se de cada amostra composta, três sub-amostras, com 1,0 Kg cada de peso; antes de serem pesadas, as sub-amostras foram passadas em peneira grossa $(0,280$ $\mathrm{mm}$ ) para retirada de material inerte e desfazer possíveis agregados existentes. Foram então colocadas em bandejas de aluminio com dimensões de $28 \mathrm{~cm} x$ $19 \mathrm{~cm} \times 4 \mathrm{~cm}$, formando uma camada de solo de aproximadamente $2 \mathrm{~cm}$ no fundo da bandeja, etiquetadas e levadas para casa-de-vegetação. As bandejas foram mantidas sob sistema de regas diárias, fazendo-se o seu uso quantas vezes fossem necessárias.

As plântulas que emergiram eram contadas, identificadas por espécie e retiradas da bandeja; as avaliações foram realizadas aos 15, 30, 60, 90 e 120 
dias após a instalação do experimento na casa de vegetação, segundo FroudWilliams et al. (1983). Quando havia dúvidas sobre a espécie em questão, a plântula era transplantada para outro recipiente, até que ela atingisse um determinado tamanho e diferenciação, e pudesse ser identificada.

Procurou-se manter boas condições de temperatura, umidade $e$ luminosidade dentro da casa de vegetação, para que não houvesse nenhum impedimento à germinação das sementes presentes nas amostras.

Devido às regas constantes, observou-se que havia a formação de uma crosta endurecida sobre a superfície de cada bandeja, o que dificultava a absorção da água. Para amenizar este problema, o solo era constantemente revolvido com auxílio de um palito de madeira, quebrando-se esta camada.

A partir da terceira época de avaliação (60 dias após instalação), observou-se que a emergência das plântulas ocorria em menor número, fez-se então, uma aplicação com nitrato de amônio na dose de $25 \mathrm{Kg} / \mathrm{ha}$, segundo recomendação de Espeby (1989).

\subsubsection{Pela separação das sementes}

Para a contagem do número de sementes, retirou-se da amostra composta três sub-amostras com peso igual a $100 \mathrm{~g}$ de solo cada. Para a separação das sementes foi utilizada a metodologia determinada por Malone (1967) e modificada por Buhler \& Maxwell (1993), sendo mostrada na Figura 2.

Cada sub-amostra de solo foi colocada em uma garrafa de centrífuga com capacidade de $250 \mathrm{ml}$; adicionou-se ao solo $100 \mathrm{ml}$ da solução dispersante, formada por $250 \mathrm{~g}$ de carbonato de potássio $\left(\mathrm{K}_{2} \mathrm{CO}_{3}\right)$, dissolvido em $500 \mathrm{ml}$ de água. Esta solução é utilizada pois o carbonato de potássio é um sal, que tem por finalidade separar o material orgânico da parte mineral do solo, obtendo-se então, uma melhor separação das sementes.

As garrafas foram colocadas em um agitador por 30 minutos para proporcionar uma dispersão dos agregados de solo e em seguida levadas para centrifugação. Utilizou-se a centrífuga 'Sorvall RC5C Plus', rotor GSA, em 
velocidade de $10.000 \mathrm{rpm}$, por um tempo de 15 minutos, separando-se assim a matéria mineral que ficou decantada no fundo do recipiente da matéria orgânica, que ficou como sobrenadante.

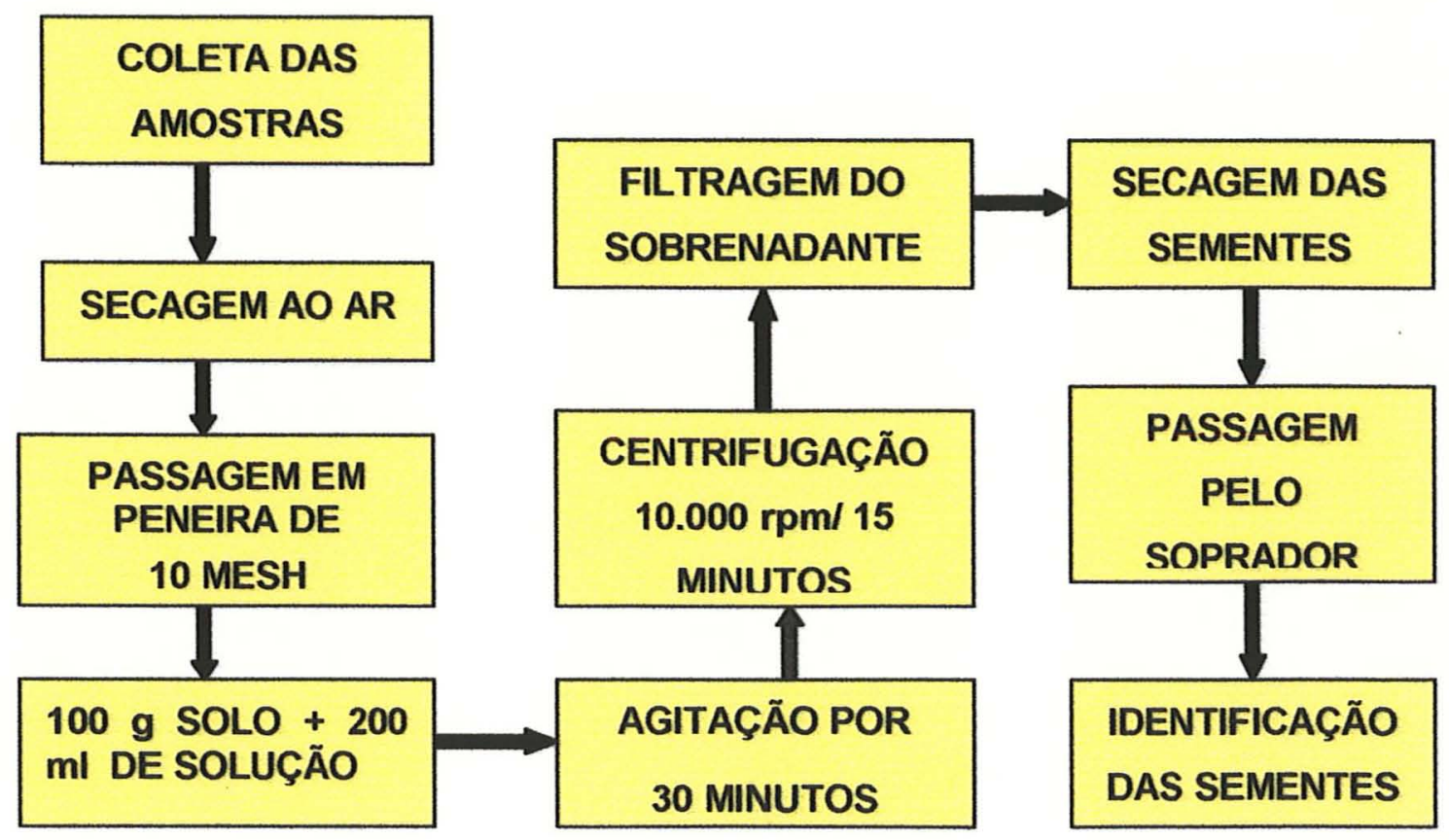

Figura 2. Esquema de extração das sementes das amostras de solo para determinação do banco de sementes do solo.

O sobrenadante foi passado por um conjunto de duas peneiras de 10 e 50 mesh de malha e o material retido foi lavado em água corrente e colocado em placa de Petri revestida com papel filtro. Após a secagem em temperatura ambiente o material resultante foi passado por um soprador de fluxo ascendente, retirando por diferença de densidade restos vegetais como casca ou palha das sementes de plantas daninhas. A separação e posterior contagem e identificação das sementes foi realizada com auxílio de uma lupa de aumento de 20X. A identificação das sementes foi baseada na comparação de sementes 
coletadas em campo ou através de imagens fotográficas de publicação, como a de Musil (1977), Groth \& Liberal (1988) e Lorenzi (1994).

\subsection{Delineamento experimental e análise estatística}

O delineamento experimental foi o de blocos casualizados com três repetições, em esquema fatorial $2 \times 5 \times 2$, sendo dois herbicidas aplicados na linha (diuron e glyphosate), cinco tratamentos de entrelinha (roçagem, sub-dose de glyphosate, guandu, lab-lab e gradagem) e duas profundidades $(0-10 \mathrm{~cm}$ e $10-20 \mathrm{~cm})$.

A análise de variância dos resultados foi realizada com o auxilio do Sistema de Análise Estatística - SANEST, e as médias submetidas ao teste de Tukey para 0,05 e 0,01\% de probabilidade. Na Tabela 6 é mostrado o esquema da análise de variância do experimento.

Tabela 6. Esquema da análise de variância do experimento

Causas da Variação

G.L.

Bloco

Tratamento na entrelinha

Herbicida

1

Profundidade

Tratamento na entrelinha*Herbicida 4

Tratamento na entrelinha*Profundidade 4

Herbicida*Profundidade 1

Tratamento na entrelinha*Herbicida*Profundidade 4 Resíduo 38 


\subsection{Parâmetros avaliados}

Para o trabalho realizado em casa-de-vegetação, avaliou-se a emergência de plântulas, através de contagem que foi realizada em quatro épocas de avaliação. Como as plântulas foram identificadas por espécie, com o valor total de cada uma delas calculou-se a freqüência que determinada espécie ocorre em cada uma das combinações.

No processo de separação física de sementes, também realizou-se a contagem de sementes presentes na amostra, identificando-se a espécie; as freqüências foram calculadas baseadas no valor total de sementes contidas na amostra e no número total de sementes de cada uma das espécies presente na amostra. 


\section{RESULTADOS E DISCUSSÃO}

\subsection{Emergência de plantas daninhas das amostras de solo em bandejas}

\subsubsection{Interação tratamento $x$ profundidade de amostragem na entrelinha, periodo seco do ano.}

Nas Tabelas 7 a 10 e Figuras de 3 a 6, estão apresentadas o número médio de plântulas emergidas a partir de amostras de solo retiradas dos diversos tratamentos aplicados na entrelinha da cultura, durante as quatro épocas de avaliação, sendo que estas amostras foram retiradas no período seco do ano.

Analisando-se a Tabela 7 (ou Figura 3), na profundidade $1(0-10 \mathrm{~cm}$ ), verifica-se que todos os tratamentos afetaram significativamente a emergência total das plantas daninhas das amostras, mesmo dentro das práticas mecânicas (gradagem e roçada) e dentre os tratamentos com leguminosas (lab-lab e guandu). Observa-se que no tratamento com a prática de gradagem ocorreu maior média de emergência, efeito este oposto da cobertura verde com guandu. Este mesmo comportamento foi encontrado na terceira avaliação (Tabela 9 e Figura 5). Na segunda avaliação nota-se que os tratamentos roçada e dose reduzida de glyphosate não apresentaram diferenças significativas entre as suas médias; já na quarta avaliação, não foi encontrada diferenças estatísticas entre as médias de dose reduzida de glyphosate e lab-lab (Tabelas 8 e 10, respectivamente). 
Figura 3. Número médio de plântulas emergidas na primeira avaliação das amostras coletadas nos tratamentos na entrelinha da cultura, independente dos herbicidas usados na linha, no período seco do ano.

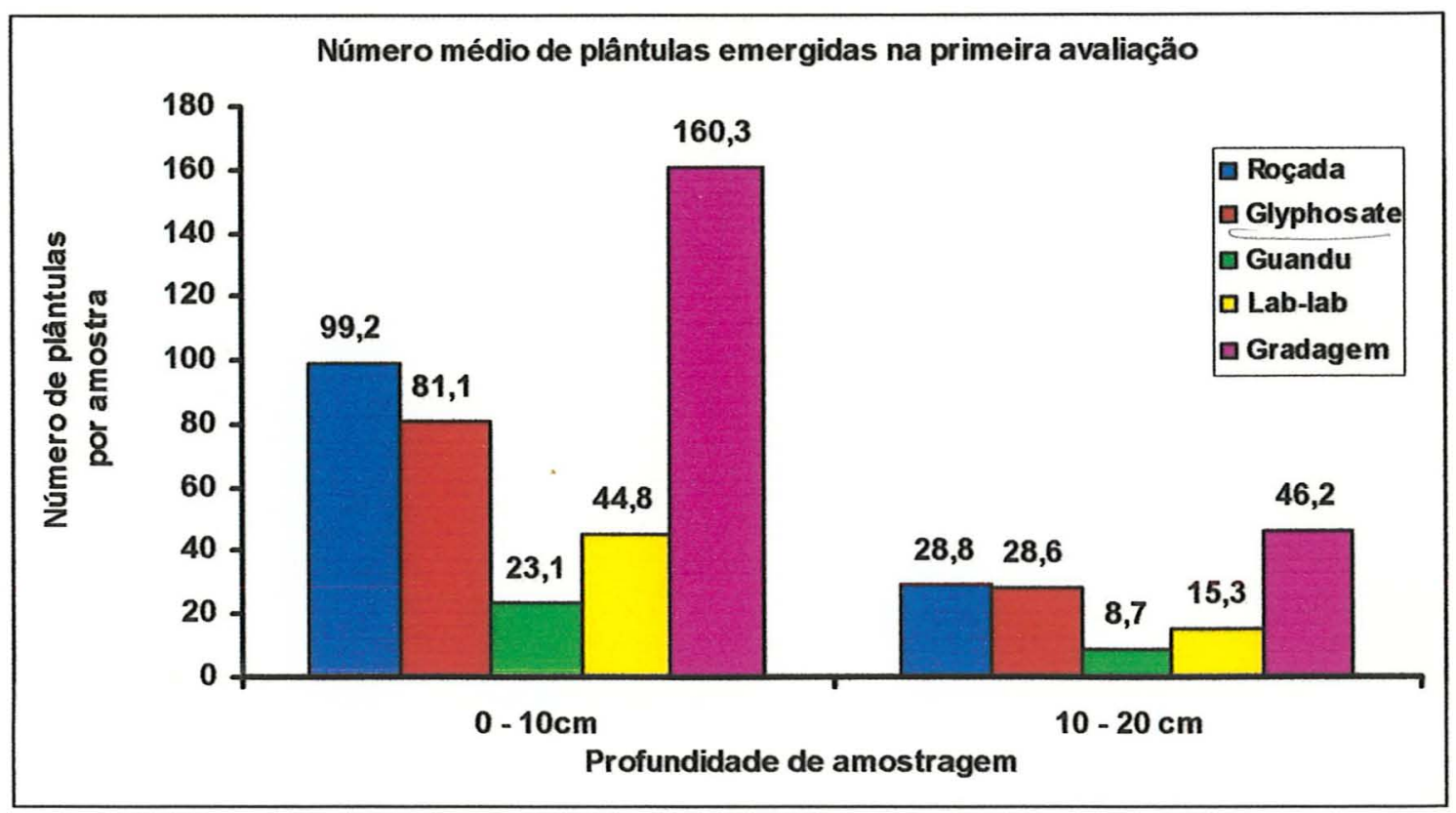

Tabela 7. Número médio de plântulas que emergiram das amostras colocadas em bandejas nos diversos tratamentos $x$ profundidades, na entrelinha da cultura, primeira avaliação, período seco do ano.

\begin{tabular}{|c|c|c|c|c|c|c|c|}
\hline Profundidade & Herbicida/linha & Roçada & Glyphosate & Guandu & Lab-lab & Gradagem & Média \\
\hline \multirow{2}{*}{$0-10 \mathrm{~cm}$} & Diuron & 98,7 & 83,1 & 22,8 & 42,3 & 162,3 & 81,9 \\
\hline & Gyphosate & 99,5 & 79,2 & 23,3 & 47,4 & 158,3 & 81,5 \\
\hline \multicolumn{2}{|c|}{ Média } & $99,2 \mathrm{Ba}$ & $81,1 \mathrm{Ca}$ & $23,1 \mathrm{Ea}$ & $44,8 \mathrm{Da}$ & $160,3 \mathrm{Aa}$ & \\
\hline Profundidade & Herbicida/linha & Roçada & Glyphosate & Guandu & Lab-lab & Gradagem & Média \\
\hline \multirow{2}{*}{$10-20 \mathrm{~cm}$} & Diuron & 27,7 & 29,9 & 8,7 & 14,4 & 46,2 & 25,4 \\
\hline & Glyphosate & 30,1 & 27,2 & 8,6 & 16,3 & 46,2 & 25,7 \\
\hline \multicolumn{2}{|c|}{ Média } & $28,8 \mathrm{Bb}$ & $28,6 \mathrm{Bb}$ & 8,7 Db & $15,3 \mathrm{Cb}$ & $46,2 \mathrm{Ab}$ & \\
\hline
\end{tabular}

Médias seguidas pelas mesmas letras maiúsculas na linha e minúsculas na coluna, não diferem entre si ao nivel de $1 \%$ de probabilidade pelo teste Tukey. C.V. $=7,28 \%$. 
Figura 4. Número médio de plântulas emergidas na segunda avaliação das amostras coletadas nos tratamentos na entrelinha da cultura, independente dos herbicidas usados na linha, no período seco do ano.

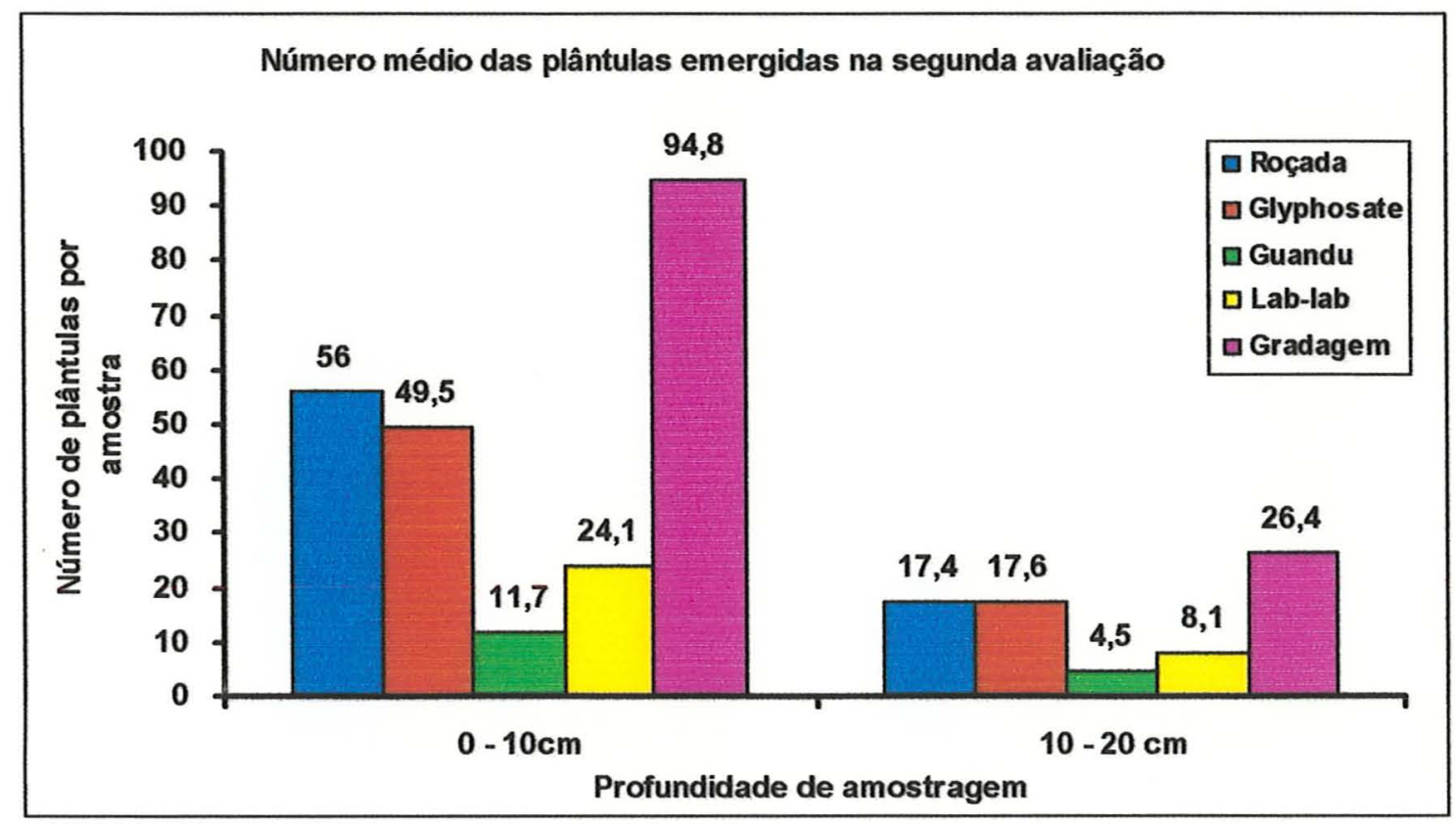

Tabela 8. Número médio de plântulas que emergiram das amostras colocadas em bandejas nos diversos tratamentos $x$ profundidades, na entrelinha da cultura, segunda avaliação, período seco do ano.

\begin{tabular}{|c|c|c|c|c|c|c|c|}
\hline Profundidade & Herbicida/linha & Roçada & Glyphosate & Guandu & Lab-lab & Gradagem & Média \\
\hline \multirow{2}{*}{$0-10 \mathrm{~cm}$} & Diuron & 55,6 & 48,0 & 10,8 & 24,5 & 94,7 & 46,7 \\
\hline & Gyphosate & 56,3 & 51,0 & 12,45 & 23,6 & 94,8 & 47,6 \\
\hline \multicolumn{2}{|c|}{ Média } & $56,0 \mathrm{Ba}$ & $49,5 \mathrm{Ba}$ & $11,7 \mathrm{Da}$ & $24,1 \mathrm{Ca}$ & $94,8 \mathrm{Aa}$ & \\
\hline Profundidade & Herbicida/linha & Roçada & Glyphosate & Guandu & Lab-lab & Gradagem & Média \\
\hline \multirow{2}{*}{$10-20 \mathrm{~cm}$} & Diuron & 17,7 & 19,1 & 4,1 & 7,3 & 27,7 & 15,2 \\
\hline & Glyphosate & 17,1 & 16,1 & 5,0 & 8,8 & 25,0 & 14,4 \\
\hline \multicolumn{2}{|c|}{ Média } & $17,4 \mathrm{Bb}$ & $17,6 \mathrm{Bb}$ & $4,5 \mathrm{Cb}$ & $8,1 \mathrm{Cb}$ & $26,4 \mathrm{Ab}$ & \\
\hline
\end{tabular}

Médias seguidas pelas mesmas letras maiúsculas na linha e minúsculas na coluna, não diferem entre si ao nível de $1 \%$ de probabilidade pelo teste Tukey. C.V. $=10,9 \%$. 
Quanto a profundidade $2(10-20 \mathrm{~cm})$, os resultados das Tabelas 7 e 8 ou Figuras 3 e 4 , evidenciam que não houve diferenças estatisticamente significativas entre as médias para os tratamentos roçada e dose reduzida de glyphosate; no entanto nota-se diferenças para os outros tratamentos. Para a terceira avaliação não encontrou-se diferenças entre os tratamentos mecânicos roçada e gradagem; para a quarta avaliação ocorreu diferenças entre dose reduzida de glyphosate e lab-lab Deve-se ressaltar também nesta última avaliação que o tratamento de cobertura com guandu apresentou as menores médias, diferenciando-se de todos os demais tratamentos.

Comparando-se os tratamentos individualmente dentro da profundidade 1 e 2, nota-se diferenças significativas nas médias, ou seja as amostras retiradas da profundidade de $0-10 \mathrm{~cm}$ proporcionaram maior emergência de plântulas em relação a profundidade de $10-20 \mathrm{~cm}$.

Supōem-se que o fato dos tratamentos de manejos de solo mecânicos (gradagem e roçada) apresentarem em geral maior número de plântulas emergindo na camada superficial de solo $(0-10 \mathrm{~cm})$, seja devido ao modo como estes implementos atuam no solo. Na prática de roçada ocorre 0 corte da vegetação, sendo a mesma mantida na superfície do solo. Se a vegetação apresentar sementes, estas podem germinar ou permanecer dormentes. Como na gradagem, a profundidade de corte é considerada pequena (menos que $10 \mathrm{~cm}$ ), consequentemente a maior quantidade de semente também permanece na superficie do solo.

Nos sistemas de manejo de solo nos quais não há inversão das camadas superficiais de solo com as camadas mais profundas, existe aumento do número de sementes de plantas daninhas nas camadas mais próximas à superficie (Yenish et al.,1992). As sementes ficam desta forma, mais expostas a alternância de temperatura e luz, podendo mais facilmente sofrer quebra de dormência. As plântulas podem então desenvolver-se e formar novas sementes, que irão enriquecer 0 banco de sementes do solo. $O$ controle 
Figura 5. Número médio de plântulas emergidas na terceira avaliação das amostras coletadas nos tratamentos na entrelinha da cultura, independente dos herbicidas usados na linha, no período seco do ano.

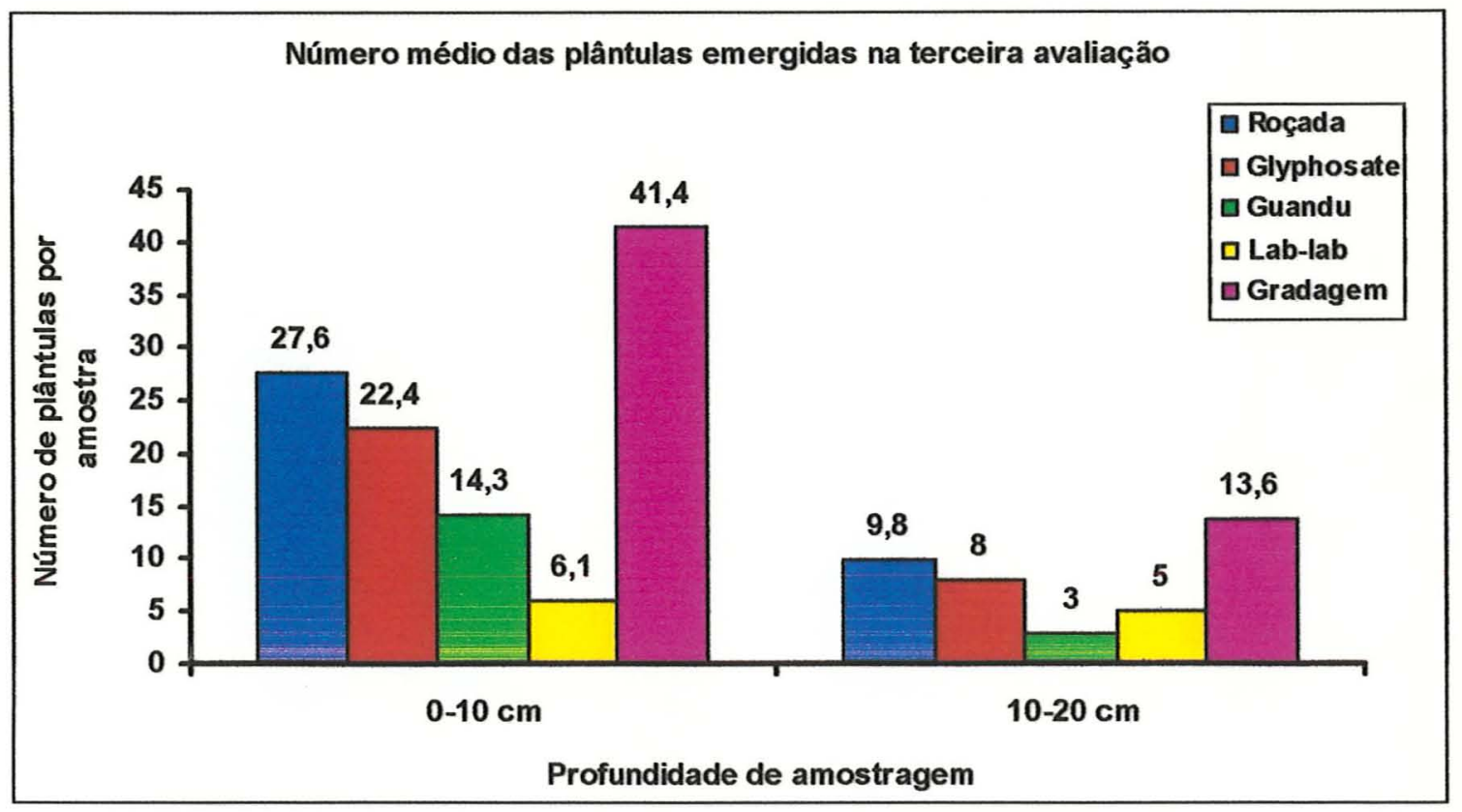

Tabela 9. Número médio de plântulas que emergiram das amostras colocadas em bandejas nos diversos tratamentos $\mathrm{x}$ profundidades, na entrelinha da cultura, terceira avaliação, período seco do ano.

\begin{tabular}{|c|c|c|c|c|c|c|c|}
\hline Profundidade & Herbicida/linha & Roçada & Glyphosate & Guandu & Lab-lab & Gradagem & Média \\
\hline \multirow{2}{*}{$0-10 \mathrm{~cm}$} & Diuron & 27,2 & 20,6 & 5,4 & 14,8 & 39,4 & 21,5 \\
\hline & Gyphosate & 28,0 & 24,2 & 6,7 & 13,7 & 43,4 & 23,2 \\
\hline \multicolumn{2}{|c|}{ Média } & $27,6 \mathrm{Ba}$ & $22,4 \mathrm{Ca}$ & $14,3 \mathrm{Da}$ & $6,1 \mathrm{Ea}$ & $41,4 \mathrm{Aa}$ & \\
\hline Profundidade & Herbicida/linha & Roçada & Glyphosate & Guandu & Lab-lab & Gradagem & Média \\
\hline \multirow{2}{*}{$10-20 \mathrm{~cm}$} & Diuron & 9,5 & 8,2 & 2,5 & 4,7 & 13,2 & 7,6 \\
\hline & Glyphosate & 10,2 & 7,7 & 3,4 & 5,3 & 14,1 & 8,1 \\
\hline \multicolumn{2}{|c|}{ Média } & $9,8 \mathrm{Ab}$ & $8,0 \mathrm{BCb}$ & $3,0 \mathrm{Db}$ & $5,0 \mathrm{CDb}$ & $13,6 \mathrm{Ab}$ & \\
\hline
\end{tabular}

Médias seguidas pelas mesmas letras maiúsculas na linha e minúsculas na coluna, não diferem entre si ao nivel de $1 \%$ de probabilidade pelo teste Tukey. C.V. $=15,1 \%$. 
Figura 6. Número médio de plântulas emergidas na quarta avaliação das amostras coletadas nos tratamentos na entrelinha da cultura, independente dos herbicidas usados na linha, no período seco do ano.

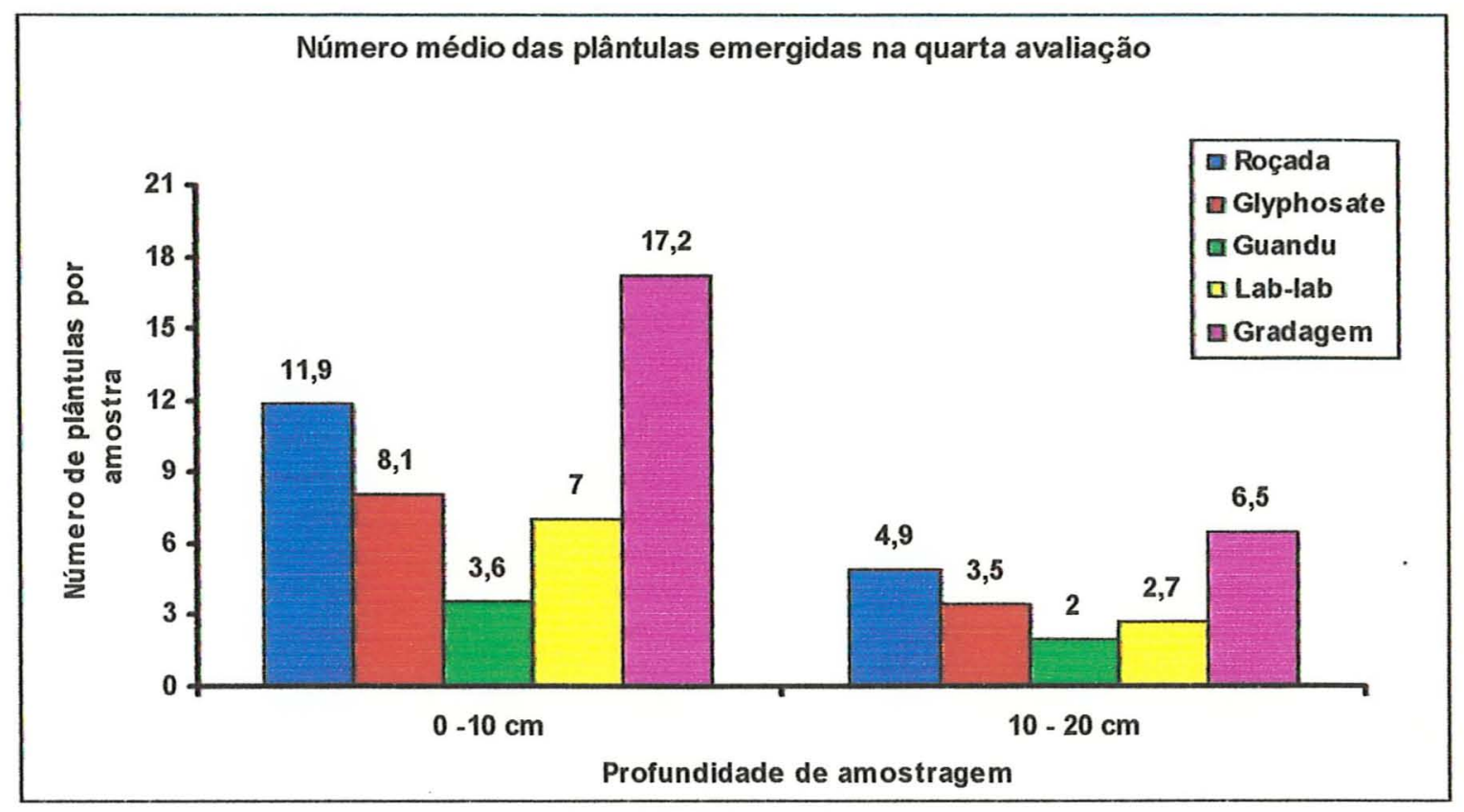

Tabela 10. Número médio de plântulas que emergiram das amostras colocadas em bandejas nos diversos tratamentos $\mathrm{x}$ profundidades, na entrelinha da cultura, quarta avaliação, período seco do ano.

\begin{tabular}{|c|c|c|c|c|c|c|c|}
\hline Profundidade & Herbicida/linha & Roçada & Glyphosate & Guandu & Labl-lab & Gradagem & Média \\
\hline \multirow{2}{*}{$0-10 \mathrm{~cm}$} & Diuron & 10,6 & 7,5 & 3,5 & 7,3 & 15,7 & 8,9 \\
\hline & Gyphosate & 13,2 & 8,6 & 3,7 & 6,6 & 18,6 & 10,2 \\
\hline \multicolumn{2}{|c|}{ Média } & $11,9 \mathrm{Ba}$ & $8,1 \mathrm{Ca}$ & 3,6 Da & $7,0 \mathrm{Ca}$ & $17,2 \mathrm{Aa}$ & \\
\hline Profundidade & Herbicida/linha & Roçada & Glyphosate & Guandu & Lab-lab & Gradagem & Média \\
\hline \multirow{2}{*}{$10-20 \mathrm{~cm}$} & Diuron & 4,1 & 3,4 & 1,7 & 3,0 & 5,6 & 3,6 \\
\hline & Glyphosate & 5,7 & 3,6 & 2,3 & 2,5 & 7,4 & 4,3 \\
\hline \multicolumn{2}{|c|}{ Média } & $4,9 \mathrm{ABb}$ & $3,5 \mathrm{BCb}$ & $2,0 \mathrm{Ca}$ & $2,7 \mathrm{BCb}$ & $6,5 \mathrm{Ab}$ & \\
\hline
\end{tabular}

Médias seguidas pelas mesmas letras maiúsculas na linha e minúsculas na coluna, não diferem entre si ao nível de $1 \%$ de probabilidade pelo teste Tukey. C.V. $=20,4 \%$ 
ineficiente dessa vegetação poderá provocar sérios problemas futuros de manejo de plantas daninhas (Ball, 1992).

Com relação às leguminosas, acredita-se que a grande massa vegetal formada tenha inibido a germinação das sementes de plantas daninhas e o estabelecimento de plântulas, talvez por competição por luz, ou então algum possivel efeito alelopático principalmente nas parcelas com o guandu, nas quais o solo permaneceu coberto por folhas, inibindo a germinação de semente. A dose reduzida do herbicida glyphosate influencia quantitativamente e qualitativamente o banco de sementes. As pesquisas tem mostrado que há um grande declínio no banco de sementes após aplicações repetidas de herbicidas (Schweizer \& Zimdahl, 1984). Salzman et al., (1988) observaram que doses reduzidas de herbicidas diminuem a produção de sementes de diversas espécies de plantas daninhas em mais de $90 \%$. No entanto, o número de sementes pode aumentar rapidamente quando $o$ uso do herbicida é descontínuo e intercalado por outras práticas de manejo.

\subsubsection{Interação tratamento $x$ profundidade de amostragem na entrelinha, período chuvoso do ano.}

Nas Figuras 7 a 10 e Tabelas 11 a 14, estão apresentados os resultados da emergência de plantas daninhas obtidos na interação tratamento $x$ profundidade de amostragem, nas quatro épocas avaliadas.

À partir dos resultados contidos nas Tabelas 11, 13 e 14 (ou Figuras 7, 9 e 10) verifica-se que na profundidade de $0-10 \mathrm{~cm}$ os tratamentos mecânicos (gradagem e roçada) e químico (glyphosate) as plantas daninhas germinaram em quantidades significativamente diferente entre si, o mesmo não acontecendo para os tratamentos com leguminosas

A Tabela 12 refere-se a segunda avaliação e os resultados nela contidos indicam diferenças entre todos os tratamentos na profundidade de 0 $10 \mathrm{~cm}$, como foi encontrado na época da seca. 
Figura 7. Número médio de plântulas emergidas na primeira avaliação das amostras coletadas nos tratamentos na entrelinha da cultura, independente dos herbicidas usados na linha, no período chuvoso do ano.

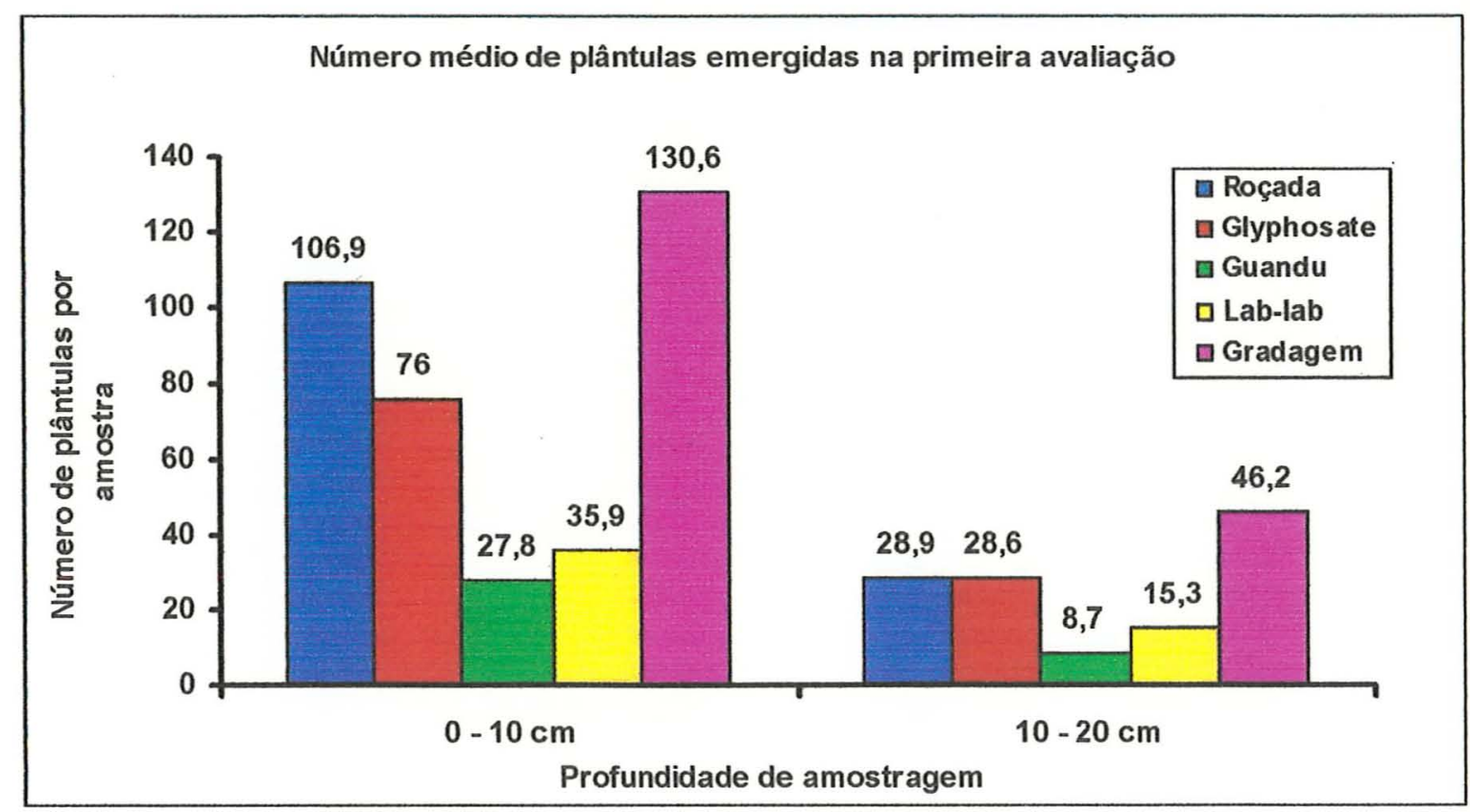

Tabela 11. Número médio de plântulas que emergiram das amostras colocadas em bandejas nos diversos tratamentos $\mathrm{x}$ profundidades, na entrelinha da cultura, primeira avaliação, período chuvoso do ano.

\begin{tabular}{|c|c|c|c|c|c|c|c|}
\hline Profundidade & Herbicida/linha & Roçada & Glyphosate & Guandu & Lab-lab & Gradagem & Média \\
\hline \multirow{2}{*}{$0-10 \mathrm{~cm}$} & Diuron & 114,7 & 76,7 & 25,2 & 35,8 & 133,1 & 77,1 \\
\hline & Gyphosate & 99,1 & 75,2 & 30,5 & 36,0 & 128,2 & 73,8 \\
\hline \multicolumn{2}{|c|}{ Média } & $106,9 \mathrm{Ba}$ & $76,0 \mathrm{Ca}$ & $27,8 \mathrm{Da}$ & $35,9 \mathrm{Da}$ & $130,6 \mathrm{Aa}$ & \\
\hline Profundidade & Herbicida/linha & Roçada & Glyphosate & Guandu & Lab-lab & Gradagem & Média \\
\hline \multirow{2}{*}{$10-20 \mathrm{~cm}$} & Diuron & 27,7 & 29,9 & 8,7 & 14,4 & 46,2 & 25,4 \\
\hline & Glyphosate & 30,1 & 27,2 & 8,6 & 16,3 & 46,2 & 25,7 \\
\hline \multicolumn{2}{|c|}{ Média } & $28,9 \mathrm{Bb}$ & $28,6 \mathrm{Bb}$ & $8,7 \mathrm{Db}$ & $15,3 \mathrm{Cb}$ & $46,2 \mathrm{Ab}$ & \\
\hline
\end{tabular}

Médias seguidas pelas mesmas letras maiúsculas na linha e minúsculas na coluna, não diferem entre si ao nível de $1 \%$ de probabilidade pelo teste Tukey. C.V. $=9,45 \%$. 
Figura 8. Número médio de plântulas emergidas na segunda avaliação das amostras coletadas nos tratamentos na entrelinha da cultura, independente dos herbicidas usados na linha, no período chuvoso do ano.

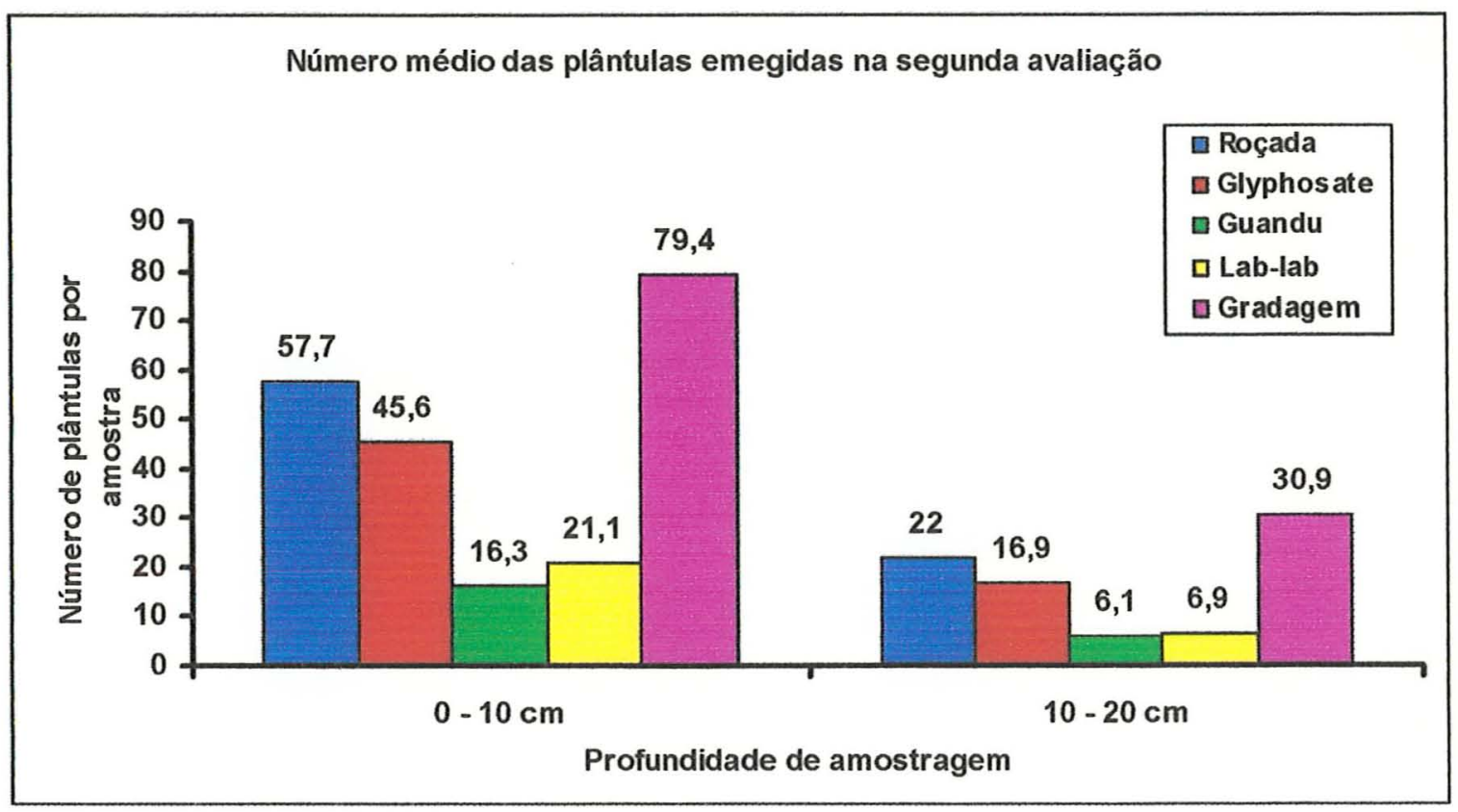

Tabela 12. Número médio de plântulas que emergiram das amostras colocadas em bandejas nos diversos tratamentos $\mathrm{x}$ profundidades, na entrelinha da cultura, segunda avaliação, período da chuva.

\begin{tabular}{|c|c|c|c|c|c|c|c|}
\hline Profundidade & Herbicida/linha & Roçada & Glyphosate & Guandu & Lab-lab & Gradagem & Média \\
\hline \multirow{2}{*}{$0-10 \mathrm{~cm}$} & Diuron & 63,1 & 43,8 & 16,4 & 20,1 & 78,1 & 44,3 \\
\hline & Gyphosate & 52,4 & 47,3 & 16,2 & 22,2 & 80,7 & 43,8 \\
\hline \multicolumn{2}{|c|}{ Média } & $57,7 \mathrm{Ba}$ & $45,6 \mathrm{Ca}$ & $16,3 \mathrm{Ea}$ & $21,1 \mathrm{Da}$ & $79,4 \mathrm{Aa}$ & \\
\hline Profundidade & Herbicida/linha & Roçada & Glyphosate & Guandu & Lab-lab & Gradagem & Média \\
\hline \multirow{2}{*}{$10-20 \mathrm{~cm}$} & Diuron & 23,9 & 17,2 & 6,2 & 6,3 & 29,6 & 16,7 \\
\hline & Glyphosate & 20,2 & 16,6 & 6,0 & 7,5 & 32,2 & 15,5 \\
\hline \multicolumn{2}{|c|}{ Média } & $22,0 \mathrm{Bb}$ & $16,9 \mathrm{Cb}$ & $6,1 \mathrm{Db}$ & $6,9 \mathrm{Db}$ & $30,9 \mathrm{Ab}$ & \\
\hline
\end{tabular}

Médias seguidas pelas mesmas letras maiúsculas na linha e minúsculas na coluna, não diferem entre si ao nível de $1 \%$ de probabilidade pelo teste Tukey. C.V. $=7,8 \%$. 
Figura 9. Número médio de plântulas emergidas na terceira avaliação das amostras coletadas nos tratamentos na entrelinha da cultura, independente dos herbicidas usados na linha, no período chuvoso do ano.

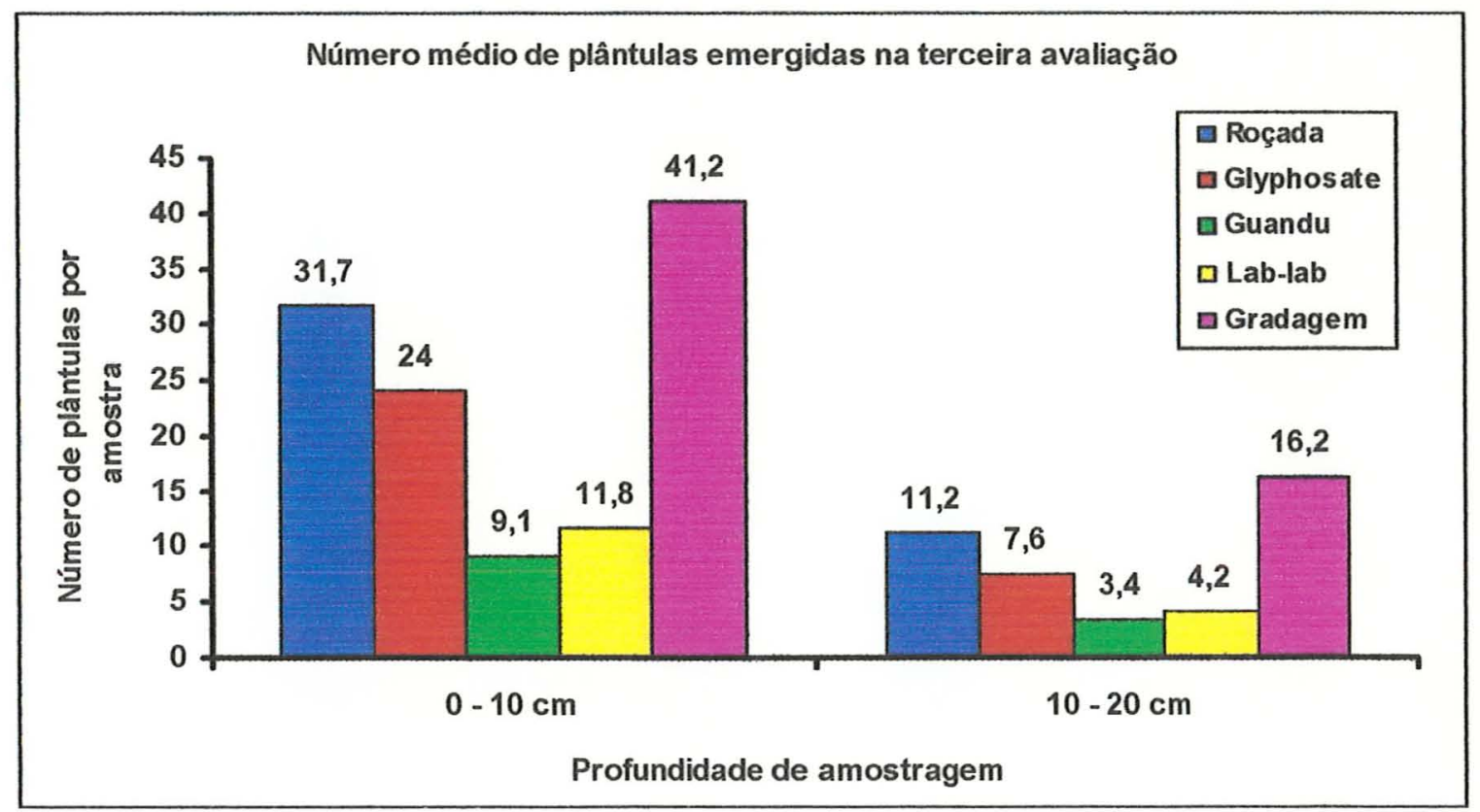

Tabela 13. Número médio de plântulas que emergiram das amostras colocadas em bandejas nos diversos tratamentos $x$ profundidades, na entrelinha da cultura, terceira avaliação, período da chuva.

\begin{tabular}{|c|c|c|c|c|c|c|c|}
\hline Profundidade & Herbicida/linha & Roçada & Glyphosate & Guandu & Lab-lab & Gradagem & Média \\
\hline \multirow{2}{*}{$0-10 \mathrm{~cm}$} & Diuron & 33,6 & 23,3 & 9,7 & 12,2 & 42,8 & 24,3 \\
\hline & Gyphosate & 29,9 & 24,6 & 8,5 & 11,5 & 39,6 & 22,8 \\
\hline \multicolumn{2}{|c|}{ Média } & $31,7 \mathrm{Ba}$ & $24,0 \mathrm{Ca}$ & $9,1 \mathrm{Da}$ & $11,8 \mathrm{Da}$ & $41,2 \mathrm{Aa}$ & \\
\hline Profundidade & Herbicida/linha & Roçada & Glyphosate & Guandu & Lab-lab & Gradagem & Média \\
\hline \multirow{2}{*}{$10-20 \mathrm{~cm}$} & Diuron & 12,0 & 8,2 & 3,5 & 4,0 & 15,5 & 8,6 \\
\hline & Glyphosate & 10,4 & 7,1 & 3,3 & 4,4 & 16,9 & 8,4 \\
\hline \multicolumn{2}{|c|}{ Média } & $11,2 \mathrm{Bb}$ & $7,6 \mathrm{Cb}$ & $3,4 \mathrm{Db}$ & $4,2 \mathrm{Db}$ & $16,2 \mathrm{Ab}$ & \\
\hline
\end{tabular}

Médias seguidas pelas mesmas letras maiúsculas na linha e minúsculas na coluna, não diferementre si ao nível de $1 \%$ de probabilidade pelo teste Tukey. C.V. $=8,99 \%$. 
Figura 10. Número médio de plântulas emergidas na quarta avaliação das amostras coletadas nos tratamentos na entrelinha da cultura, independente dos herbicidas usados na linha, no período chuvoso do ano.

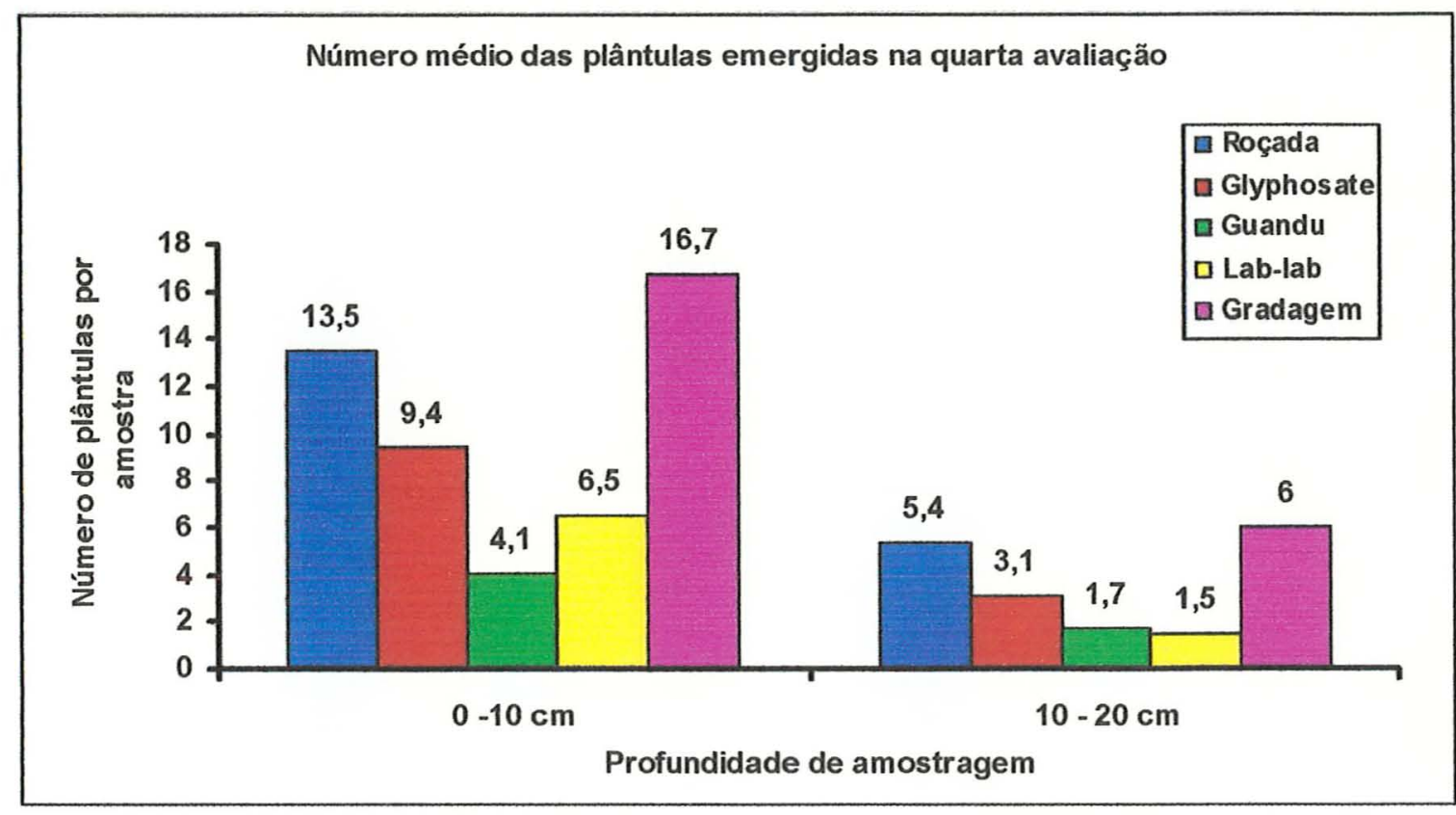

Tabela 14. Número médio de plântulas que emergiram das amostras colocadas em bandejas nos diversos tratamentos $\mathrm{x}$ profundidades, na entrelinha da cultura, quarta avaliação, período da chuva.

\begin{tabular}{clrccccc}
\hline Profundidade & Herbicida/linha & Roçada & Glyphosate & Guandu & Lablab & Gradagem & Média \\
\hline \multirow{2}{*}{$0-10 \mathrm{~cm}$} & Diuron & 15,6 & 9,4 & 3,6 & 6,7 & 18,4 & 10,7 \\
& Gyphosate & 11,4 & 9,4 & 4,5 & 6,3 & 15,1 & 9,3 \\
\hline \multirow{2}{*}{ Média } & $13,5 \mathrm{Ba}$ & $9,4 \mathrm{Ca}$ & $4,1 \mathrm{Da}$ & $6,5 \mathrm{Da}$ & $16,7 \mathrm{Aa}$ & \\
\hline \multirow{2}{*}{$\begin{array}{c}\text { Profundidade } \\
\text { Herbicida/linha }\end{array}$} & Roçada & Glyphosate & Guandu & Lab-lab & Gradagem & Média \\
\hline & Diuron & 5,6 & 2,7 & 1,7 & 2,0 & 6,7 & 3,8 \\
& Glyphosate & 5,1 & 3,4 & 1,6 & 1,1 & 5,33 & 3,3 \\
\hline
\end{tabular}

Médias seguidas pelas mesmas letras maiúsculas na linha e minúsculas na coluna, não diferem entre si ao nível de $1 \%$ de probabilidade pelo teste Tukey. C.V. $=19,9 \%$. 
Na profundidade de $10-20 \mathrm{~cm}$, os resultados evidenciam que em três avaliações $\left(1^{\mathrm{a}}, 3^{\mathrm{a}}\right.$ e $\left.4^{\mathrm{a}}\right)$, as médias para as leguminosas guandu e lab-lab não apresentaram diferenças, talvez porque a chuva tenha proporcionado ao lab-lab formar uma maior massa vegetativa, inibindo por conseguinte o estabelecimento das plantas daninhas.

Comparando-se os tratamentos individualmente dentro das profundidades 0-10 e 10-20 cm, observou-se uma mesma tendência no comportamento destes em relação a época da seca. Os tratamentos apresentam-se diferentes dentro das profundidades estudadas; fica evidente então que a camada superficial do solo apresenta uma maior quantidade de sementes em relação a outras.

De forma geral, nessa estação de coleta de amostra, observou-se que os tratamentos mecânicos apresentaram um maior número de sementes aptas a germinar, principalmente com a gradagem, certamente pelas mesmas razões daquelas ocorridas na época da seca.

Diferenças nos tratamentos durante as duas épocas de coleta de amostra foram pequenas, em termos de número de plântulas, encontrando-se na época da seca números poucos maiores que na chuva.

\subsubsection{Interação herbicida $x$ profundidade de amostragem, na linha de plantio, no período seco do ano.}

As Figuras 11 a 13 e Tabelas 15 a 17 , contém os resultados referentes ao número de plântulas obtida em três épocas de avaliação. Os resultados da quarta época são encontrados na Tabela 18 ( ou Figura 14), visto que nesta etapa a interação herbicida $x$ profundidade não foi significativa, sendo somente significativo o fator profundidade.

Analisando-se essa interação, observa-se que tanto em parcelas onde foram utilizadas o diuron, como o glyphosate ocorreram diferenças significativas nas médias da profundidade $0-10 \mathrm{~cm}$ e $10-20 \mathrm{~cm}$. Uma interação significativa quer dizer que os fatores em questão são dependentes, ou seja, há 
Figura 11. Número médio de plântulas emergidas na primeira avaliação das amostras coletadas nos tratamentos na linha da cultura, independente dos tratamentos usados na entrelinha, no período seco do ano.

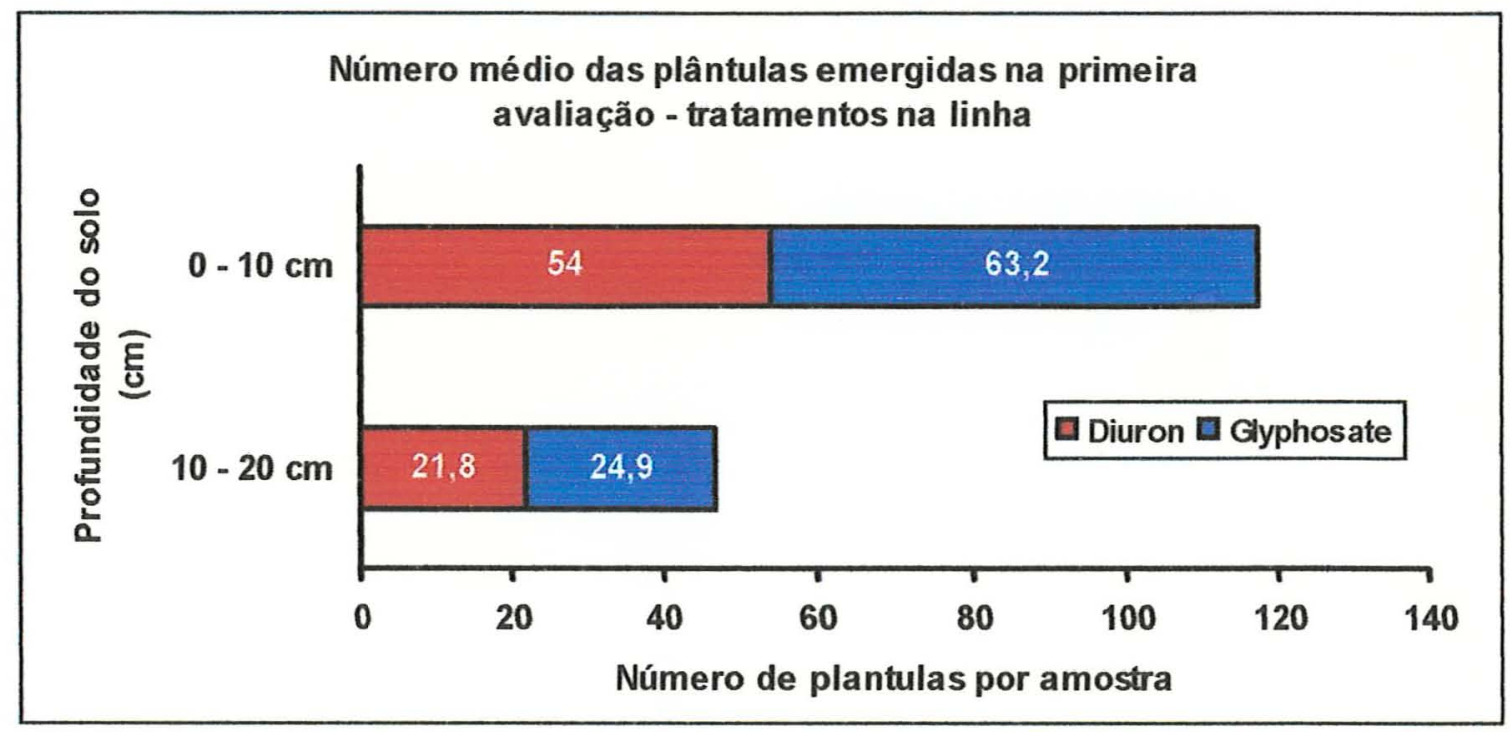

Tabela 15. Número médio de plântulas que emergiram das amostras colocadas em bandejas nos diversos tratamentos x profundidades, na linha da cultura, primeira avaliação, período seco do ano.

\begin{tabular}{lcc}
\hline & \multicolumn{2}{c}{ Diuron } \\
\cline { 2 - 3 } Tratamentos & $0-10 \mathrm{~cm}$ & $10-20 \mathrm{~cm}$ \\
\hline Roçada & 49,4 & 24,0 \\
Glyphosate & 60,3 & 22,0 \\
Guandu & 54,5 & 20,6 \\
Lab-lab & 53,7 & 20,1 \\
Gradagem & 52,3 & 22,2 \\
\hline Média & $54,0 \mathrm{Ab}$ & $21,8 \mathrm{Bb}$ \\
\hline & & \\
Tratamentos & $0-10 \mathrm{~cm}$ & 27,5 \\
\hline Roçada & 65,0 & 22,0 \\
Glyphosate & 60,4 & 23,5 \\
Guandu & 63,3 & 21,5 \\
Lab-lab & 65,1 & 30,0 \\
Gradagem & 62,3 & $24,9 \mathrm{Ba}$ \\
\hline Média & $63,2 \mathrm{Aa}$ & $\mathrm{cm}$ \\
\hline
\end{tabular}

Médias seguidas por mesmas letras maiúsculas na linha e minúsculas na coluna, não diferem entre si ao nível de $5 \%$ de probabilidade pelo teste de Tukey. C.V.\% $=10,0 \%$ 
Figura 12. Número médio de plântulas emergidas na segunda avaliação das amostras coletadas nos tratamentos na linha da cultura, independente dos tratamentos usados na entrelinha, no período seco do ano

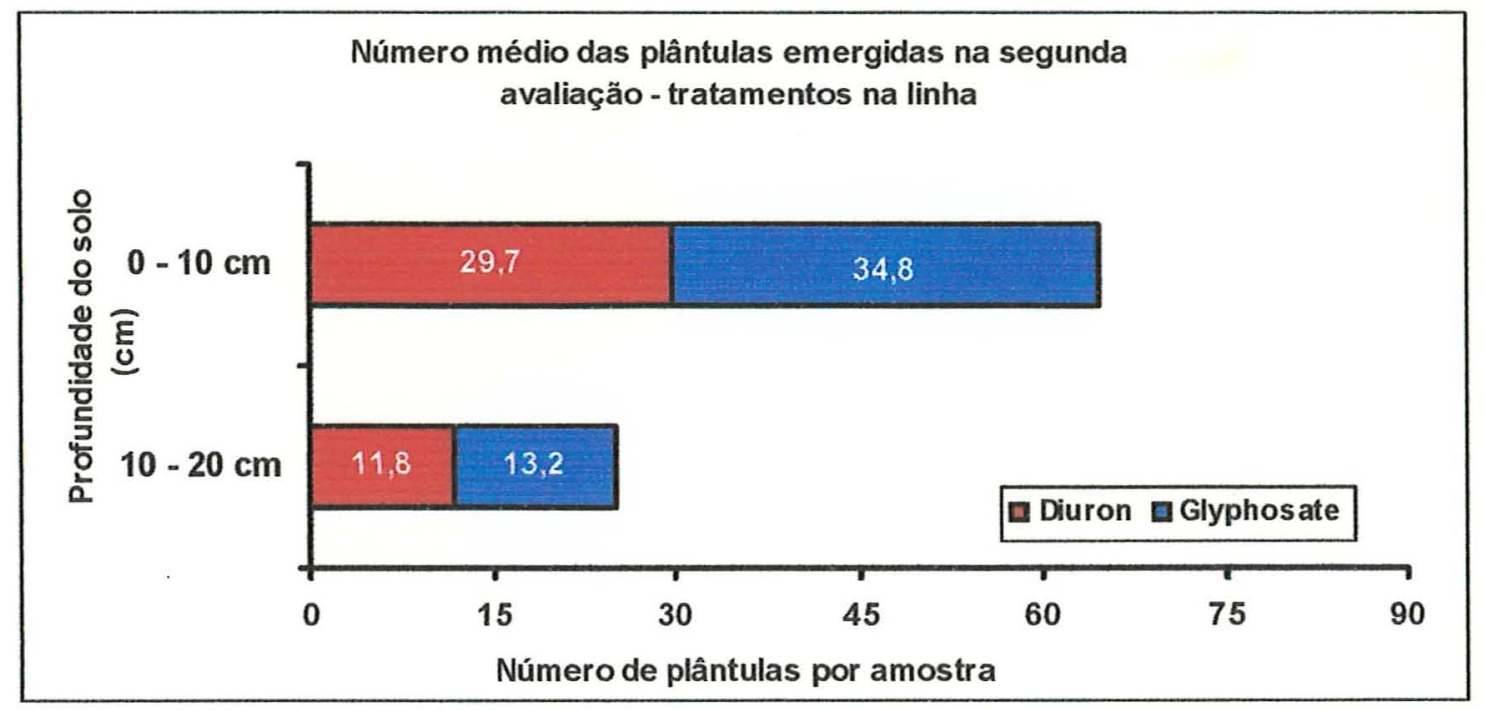

Tabela 16. Número médio de plântulas que emergiram das amostras colocadas em bandejas nos diversos tratamentos $x$ profundidades, na linha da cultura, segunda avaliação, período seco do ano.

\begin{tabular}{lcc}
\hline & \multicolumn{2}{c}{ Diuron } \\
\cline { 2 - 3 } Tratamentos & $0-10 \mathrm{~cm}$ & $10-20 \mathrm{~cm}$ \\
\hline Roçada & 28,5 & 11,0 \\
Glyphosate & 29,1 & 11,7 \\
Guandu & 28,3 & 11,6 \\
Lab-lab & 30,1 & 11,6 \\
Gradagem & 32,5 & 11,8 \\
\hline Média & $29,7 \mathrm{Ab}$ & $11,8 \mathrm{Bb}$ \\
\hline & & \\
Tratamentos & $0-10 \mathrm{~cm}$ & Glyphosate \\
\hline Roçada & 35,8 & $10-20 \mathrm{~cm}$ \\
Glyphosate & 36,5 & 12,1 \\
Guandu & 33,8 & 12,5 \\
Lab-lab & 34,8 & 12,6 \\
Gradagem & 32,7 & 11,1 \\
Média & $34,8 \mathrm{Aa}$ & 17,6 \\
\hline
\end{tabular}

Médias seguidas por mesmas letras maiúsculas na linha e minúsculas na coluna, não diferem entre si ao nível de $5 \%$ de probabilidade pelo teste de Tukey. C.V. $\%=11,4 \%$. 
Figura 13. Número médio de plântulas emergidas na terceira avaliação das amostras coletadas nos tratamentos na linha da cultura, independente dos tratamentos usados na entrelinha, no período seco do ano.

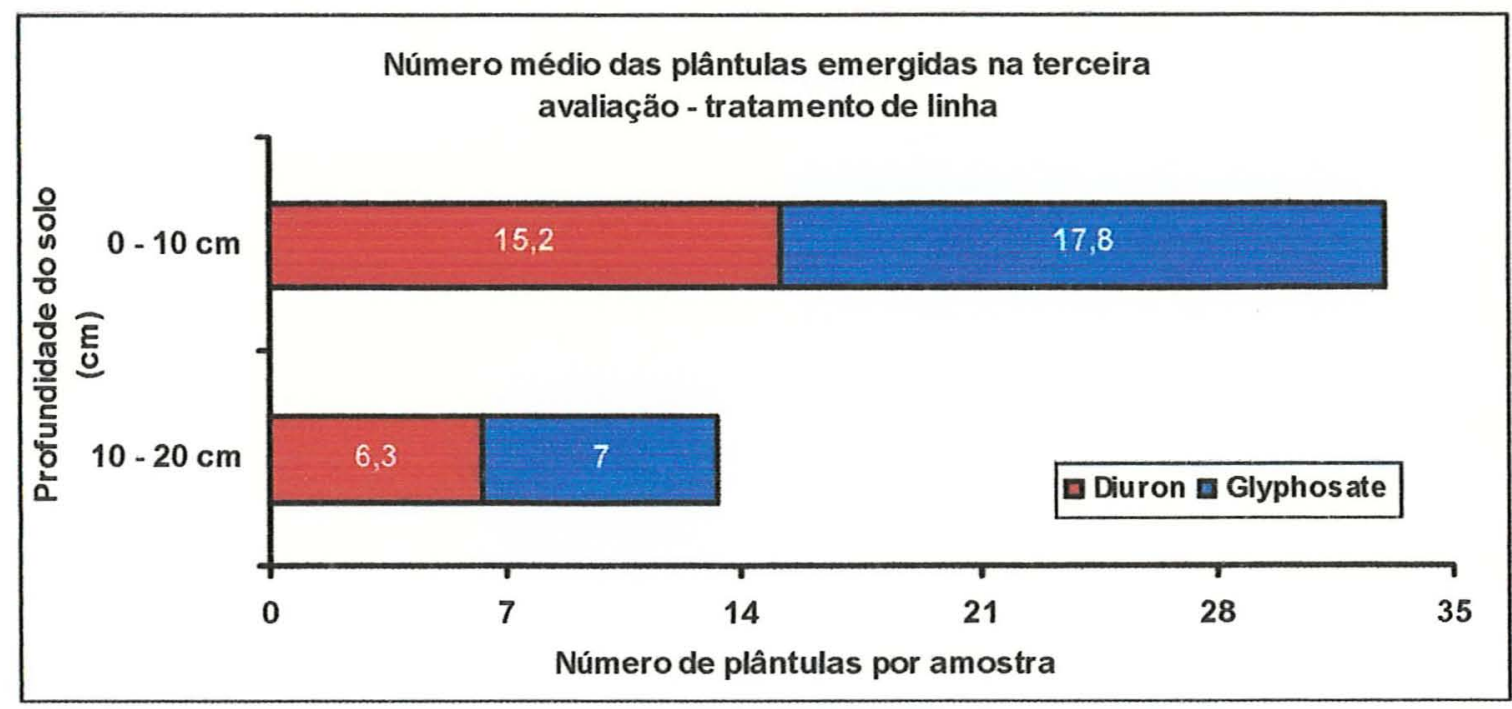

Tabela 17 Número médio de plântulas que emergiram das amostras colocadas em bandejas nos diversos tratamentos $\mathrm{x}$ profundidades, na linha da cultura, terceira avaliação, período seco do ano.

\begin{tabular}{|c|c|c|}
\hline \multirow[b]{2}{*}{ Tratamentos } & \multicolumn{2}{|c|}{ Diuron } \\
\hline & $0-10 \mathrm{~cm}$ & $10-20 \mathrm{~cm}$ \\
\hline Roçada & 16,5 & 5,4 \\
\hline Glyphosate & 12,6 & 6,5 \\
\hline Guandu & 15,0 & 5,7 \\
\hline Lab-lab & 15,1 & 6,7 \\
\hline Gradagem & 16,6 & 7,0 \\
\hline \multirow[t]{2}{*}{ Média } & $15,2 \mathrm{Ab}$ & $6,3 \mathrm{Bb}$ \\
\hline & \multicolumn{2}{|c|}{ Glyphosate } \\
\hline Tratamentos & $0-10 \mathrm{~cm}$ & $10-20 \mathrm{~cm}$ \\
\hline Roçada & 16,1 & 7,0 \\
\hline Glyphosate & 19,7 & 7,0 \\
\hline Guandu & 17,2 & 6,6 \\
\hline Lab-lab & 16,3 & 5,6 \\
\hline Gradagem & 19,7 & 9,1 \\
\hline Média & $17,8 \mathrm{Aa}$ & $7,0 \mathrm{Ba}$ \\
\hline
\end{tabular}

Médias seguidas por mesmas letras maiúsculas na linha e minúsculas na coluna, não diferem entre si ao nivel de $5 \%$ de probabilidade pelo teste de Tukey. C.V. $\%=11,6 \%$. 
nesse caso, há influência do herbicida na profundidade.

A comparação do diuron com o glyphosate nas profundidades de 0 $10 \mathrm{~cm}$ e de $10-20 \mathrm{~cm}$, também resultou em diferenças significativas das suas médias para as três épocas avaliadas.

Supōem-se que esses resultados sejam devido a própria forma de aplicação desses produtos; o diuron é aplicado em pré-emergência sobre a superfície do solo e o glyphosate em pós-emergência na vegetação jovem. Há na verdade uma pequena movimentação do diuron para camadas mais profundas do solo, visto que as características do herbicida que controla sua dinâmica no solo determina sua permanência na zona de germinação das sementes (3-5 cm superficiais). Deve-se considerar no entanto, as sementes recalcitrantes no banco de sementes, devido a utilização anterior de diversas práticas agrícolas.

Quanto ao tratamento com glyphosate apresentar maiores medias de emergência de plântulas, possivelmente é decorrente da ausência do efeito residual deste herbicida. Na literatura há diversos relatos sobre combinações de herbicidas com outras práticas culturais e cultivo mecânico como o de Ball (1992); Cardina et al. (1991); Cardina \& Norsquay (1997) e Buhler et al., (1997).

A Tabela 18 e Figura 14 apresentam os resultados obtidos na quarta avaliação, onde obteve-se significância de médias para o fator profundidade. Observa-se que o número médio de plântulas que emergiram a partir de amostras de solo retiradas da profundidade de $0-10 \mathrm{~cm}$ apresenta diferença significativa daquele obtido na profundidade de $10-20 \mathrm{~cm}$, independente do herbicida que foi utilizado na linha. Outro fato que também pode ser notado é que o glyphosate sempre apresenta maiores emergências que o diuron, na profundidade de $0-10 \mathrm{~cm}$ e de $10-20 \mathrm{~cm}$. Como já foi relatado, supõem-se que esses resultados sejam devido a ausência do poder residual do produto e também em maiores profundidades deve-se considerar as sementes recalcitrantes, bem como uma maior atividade de microrganismos nessa área, fazendo com que as sementes cheguem a camadas mais profundas do solo. 
Figura 14. Número médio de plântulas emergidas na quarta avaliação das amostras coletadas nos tratamentos na linha da cultura, independente dos tratamentos usados na entrelinha, no período seco do ano.

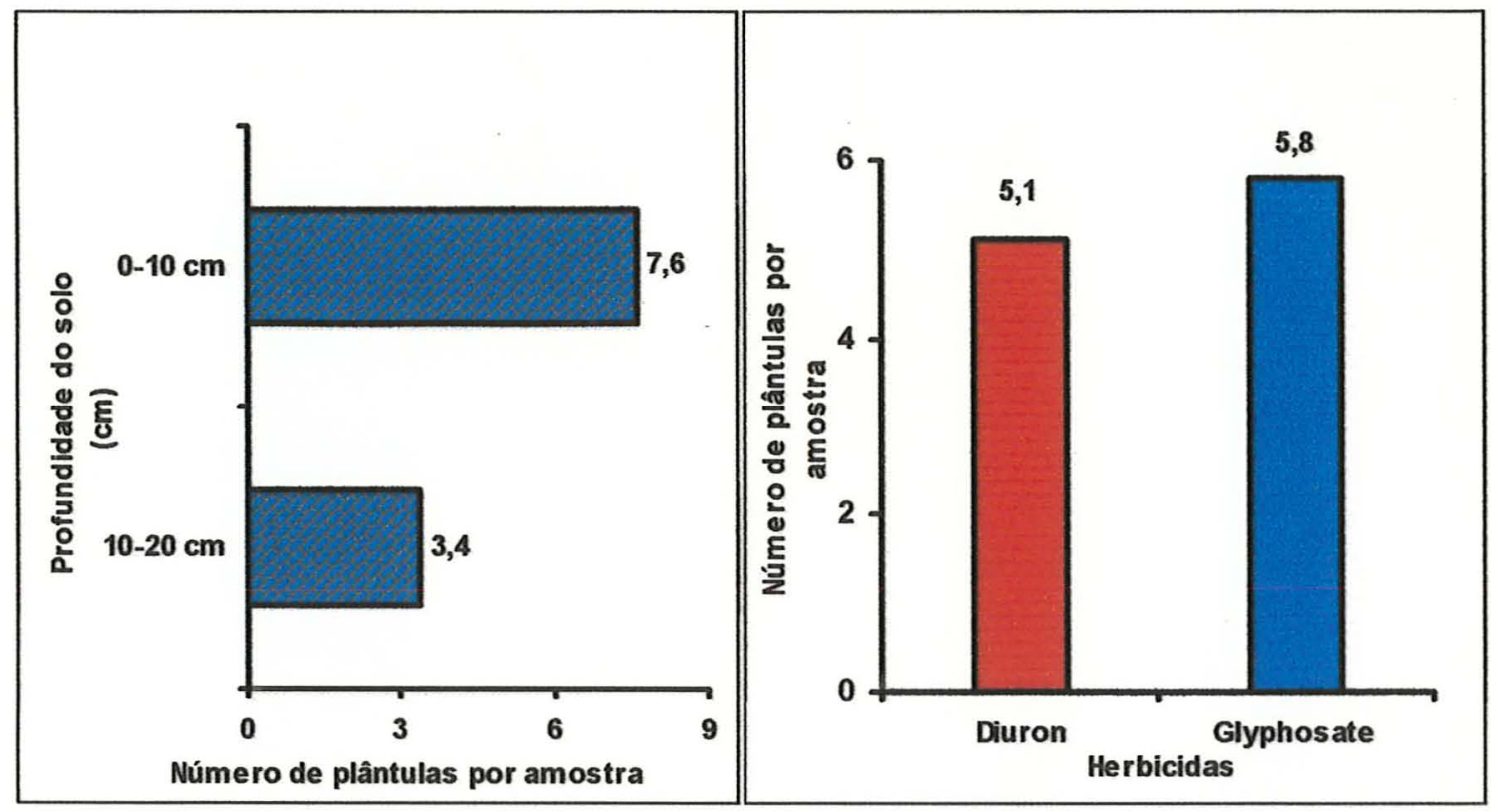

Tabela 18. Número médio de plântulas que emergiram das amostras colocadas em bandejas nas duas profundidades, na linha da cultura, quarta avaliação, período seco do ano.

\begin{tabular}{lccc}
\hline \multicolumn{1}{c}{ 0-10 cm } & Diuron & Glyphosate & Média \\
\hline Roçada & 7,8 & 8,3 & \\
Glyphosate & 6,6 & 7,2 & $7,6 \mathrm{a}$ \\
Guandu & 6,4 & 8,4 & \\
Lab-lab & 6,8 & 7,7 & \\
Gradagem & 7,7 & 8,9 & Média \\
\hline \multicolumn{1}{c}{$10-20 \mathrm{~cm}$} & Diuron & Glyphosate & \\
\hline Roçada & 3,1 & 3,1 & $3,4 \mathrm{~b}$ \\
Glyphosate & 3,0 & 3,9 & \\
Guandu & 3,2 & 2,8 & \\
Lab-lab & 2,6 & 3,0 & \\
Gradagem & 3,3 & 5,1 & \\
\hline
\end{tabular}

Médias seguidas por mesmas letras maiúsculas na linha e minúsculas na coluna, não diferem entre si ao nível de $1 \%$ de probabilidade pelo teste de Tukey. C.V. $\%=19,8 \%$. 


\subsubsection{Interação herbicida $x$ profundidade de amostragem, na linha de plantio, na época chuvosa do ano}

As médias das emergências de plantas daninhas entre tratamentos e profundidade de amostragem que ocorreram na linha de plantio durante as quatro avaliações estão apresentadas nas Figuras 15 a 18 e Tabelas 19 a 22.

Pelos resultados obtidos observa-se que o diuron dentro das duas profundidades $(0-10$ e $10-20 \mathrm{~cm})$ apresentou médias significativamente diferentes, para todas as quatro avaliações. O mesmo comportamento foi também observado para o glyphosate.

Estes resultados concordam com aqueles obtidos durante a estação seca, reforçando o fato de que esses produtos influenciam no banco de sementes de forma diferenciada dentro das profundidades do solo.

Em relação à comparação do diuron com o glyphosate numa mesma profundidade, observa-se um efeito diferenciado daquele ocorrido na época da seca. Para a primeira e segunda avaliações, o diuron não apresentou médias com diferenças significativas em relação ao glyphosate. Porém, nas avaliações seguintes, foram detectadas diferenças. Supõem-se que algum fator ambiental tenha provocado esse comportamento durante o período da chuva.

$\mathrm{Na}$ profundidade de $10-20 \mathrm{~cm}$, nas duas primeiras avaliações, os tratamentos herbicidas influenciaram as médias de germinação das plantas daninhas de forma diferenciada, enquanto que nas duas últimas não houve diferenças entre - diuron e glyphosate. Este resultado coincide com os observados na época da seca. De maneira geral, o glyphosate permitiu um maior enriquecimento que o diuron, nas duas profundidades. 
Figura 15.Número médio de plântulas emergidas na primeira avaliação das amostras coletadas nos tratamentos na linha da cultura, independente dos tratamentos usados na entrelinha, no período chuvoso do ano.

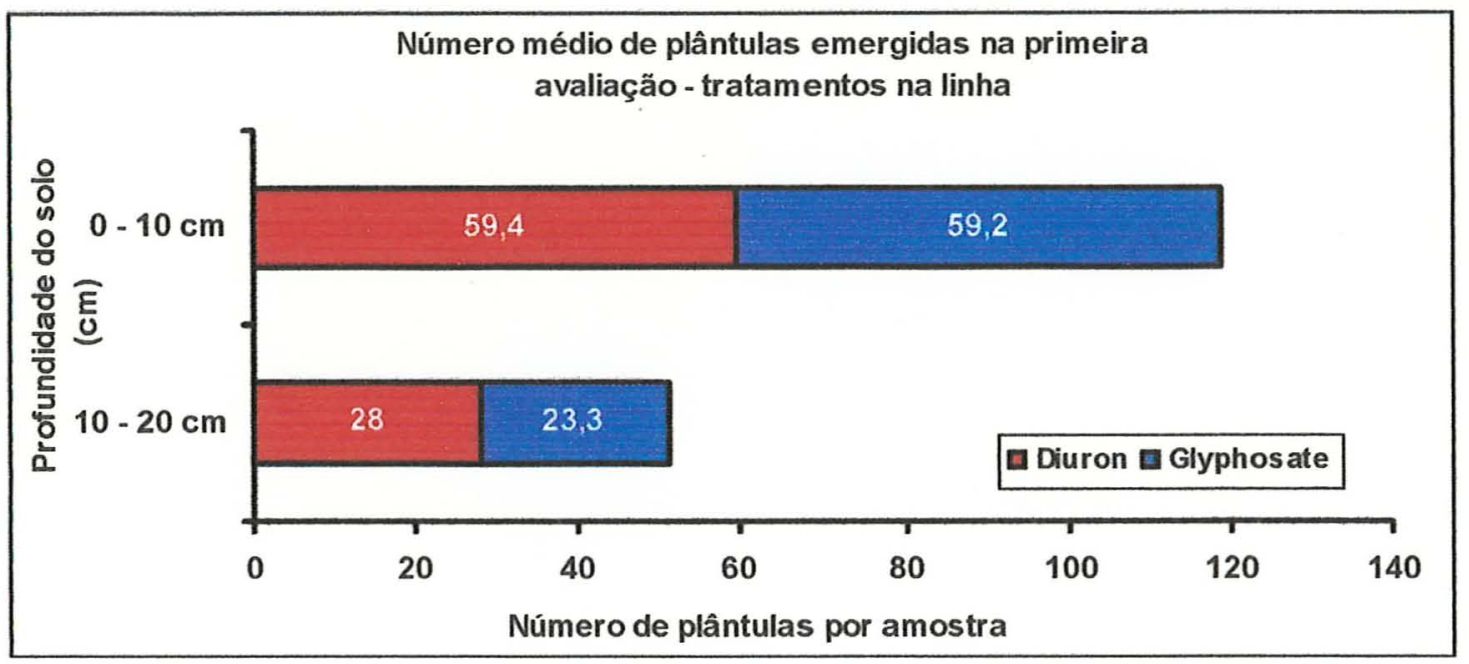

Tabela 19. Número médio de plântulas que emergiram das amostras colocadas em bandejas nos diversos tratamentos $x$ profundidades, na linha da cultura, primeira avaliação, no período chuvoso.

\begin{tabular}{lcc}
\hline & \multicolumn{2}{c}{ Diuron } \\
\cline { 2 - 3 } Tratamentos & $0-10 \mathrm{~cm}$ & $10-20 \mathrm{~cm}$ \\
\hline Roçada & 61,8 & 27,3 \\
Glyphosate & 57,8 & 25,1 \\
Guandu & 57,2 & 30,1 \\
Lab-lab & 59,0 & 27,7 \\
Gradagem & 61,0 & 29,9 \\
\hline Média & $59,4 \mathrm{Aa}$ & $28,0 \mathrm{Ba}$ \\
\hline & & Glyphosate \\
Tratamentos & $0-10 \mathrm{~cm}$ & $10-20 \mathrm{~cm}$ \\
\hline Roçada & 60,3 & 23,2 \\
Glyphosate & 58,6 & 21,3 \\
Guandu & 59,5 & 22,5 \\
Lab-lab & 59,3 & 25,5 \\
Gradagem & 59,3 & 24,1 \\
\hline Média & $59,2 \mathrm{Aa}$ & $23,3 \mathrm{Bb}$
\end{tabular}

Médias seguidas por mesmas letras maiúsculas na linha e minúsculas na coluna, não diferem entre si ao nivel de $5 \%$ de probabilidade pelo teste de Tukey. C.V. $\%=6,3 \%$. 
Figura 16. Número médio de plântulas emergidas na segunda avaliação das amostras coletadas nos tratamentos na linha da cultura, independente dos tratamentos usados na entrelinha, no período chuvoso do ano.

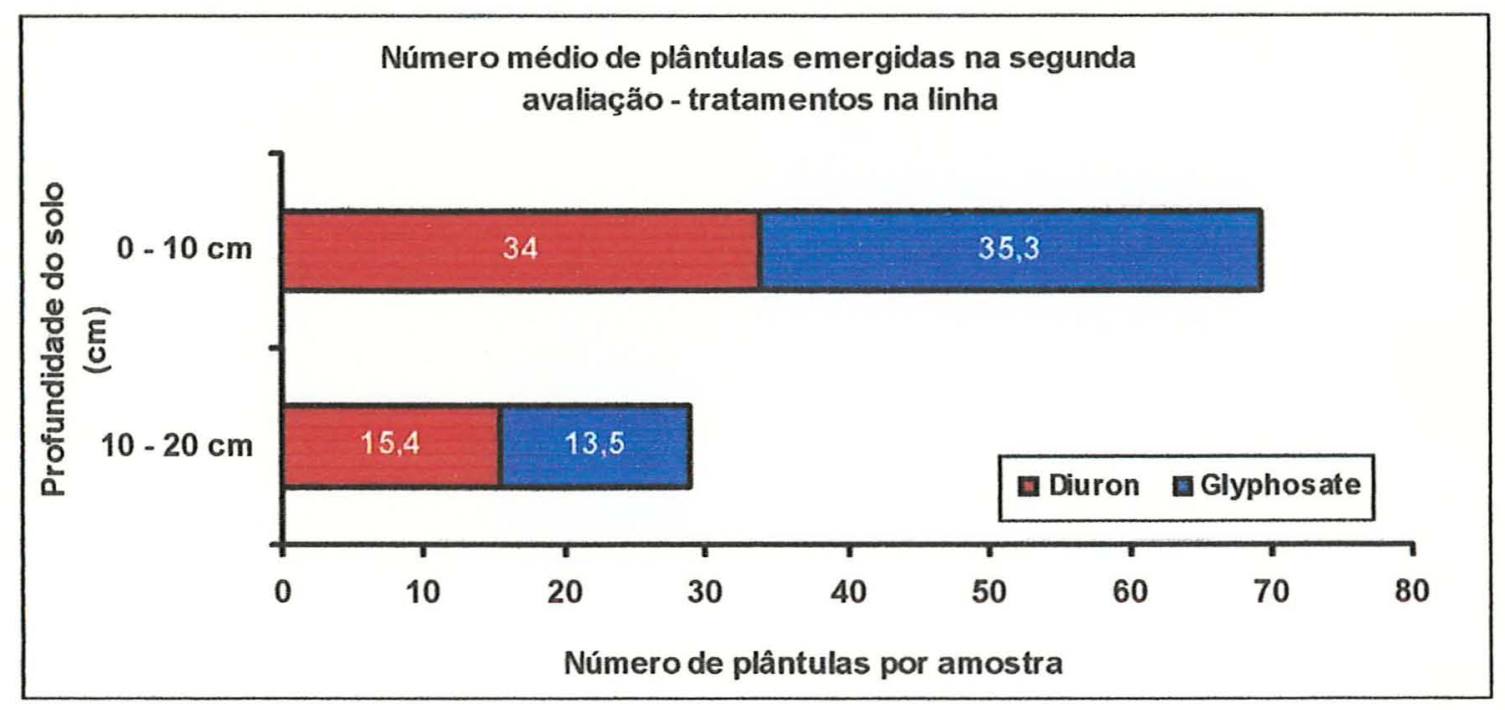

Tabela 20. Número médio de plântulas que emergiram das amostras colocadas em bandejas nos diversos tratamentos $x$ profundidades, na linha da cultura, segunda avaliação, no período chuvoso.

\begin{tabular}{lcc}
\hline & \multicolumn{2}{c}{ Diuron } \\
\cline { 2 - 3 } Tratamentos & $0-10 \mathrm{~cm}$ & $10-20 \mathrm{~cm}$ \\
\hline Roçada & 31,7 & 15,2 \\
Glyphosate & 33,7 & 16,2 \\
Guandu & 35,3 & 15,0 \\
Lab-lab & 33,4 & 14,9 \\
Gradagem & 36,1 & 15,7 \\
\hline Média & $34,0 \mathrm{Aa}$ & $15,4 \mathrm{Ba}$ \\
\hline & & \\
Tratamentos & $0-10 \mathrm{~cm}$ & $10-20 \mathrm{~cm}$ \\
\hline Roçada & 34,7 & 14,0 \\
Glyphosate & 35,4 & 12,0 \\
Guandu & 33,2 & 12,1 \\
Lab-lab & 37,2 & 14,1 \\
Gradagem & 36,0 & 15,4 \\
\hline Média & $35,3 \mathrm{Aa}$ & $13,5 \mathrm{Bb}$ \\
\hline
\end{tabular}

Médias seguidas por mesmas letras maiúsculas na linha e minúsculas na coluna, não diferem entre si ao nível de $5 \%$ de probabilidade pelo teste de Tukey. C.V. $\%=8,6 \%$. 
Figura 17. Número médio de plântulas emergidas na terceira avaliação das amostras coletadas nos tratamentos na linha da cultura, independente dos tratamentos usados na entrelinha, no período chuvoso do ano.

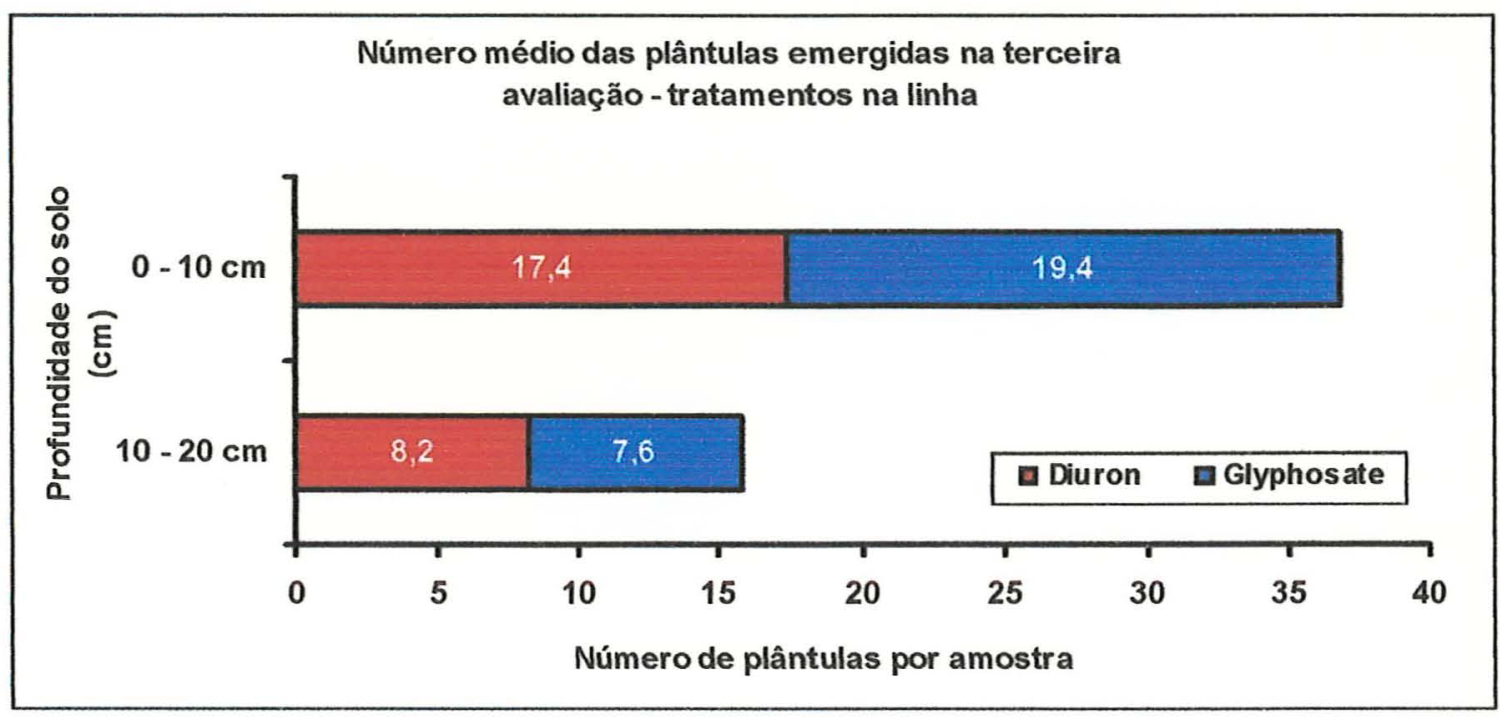

Tabela 21. Número médio de plântulas que emergiram das amostras colocadas em bandejas nos diversos tratamentos $\mathrm{x}$ profundidades, na linha da cultura, terceira avaliação, no período da chuva.

\begin{tabular}{lcc}
\hline & \multicolumn{2}{c}{ Diuron } \\
\cline { 2 - 3 } Tratamentos & $0-10 \mathrm{~cm}$ & $10-20 \mathrm{~cm}$ \\
\hline Roçada & 18,1 & 8,3 \\
Glyphosate & 17,8 & 8,4 \\
Guandu & 15,9 & 8,0 \\
Lab-lab & 18,7 & 8,5 \\
Gradagem & 16,1 & 7,5 \\
\hline Média & $17,4 \mathrm{Ab}$ & $8,2 \mathrm{Ba}$ \\
\hline & \multicolumn{3}{c}{ Glyphosate } \\
Tratamentos & $0-10 \mathrm{~cm}$ & $10-20 \mathrm{~cm}$ \\
\hline Roçada & 18,2 & 7,2 \\
Glyphosate & 20,4 & 7,7 \\
Guandu & 19,7 & 6,7 \\
Lab-lab & 18,3 & 8,4 \\
Gradagem & 20,1 & 7,6 \\
\hline Média & $19,4 \mathrm{Aa}$ & $7,6 \mathrm{Ba}$ \\
\hline Médias seguidas por mesmas letras maiúsculas na linha e minúsculas na coluna, não diferem &
\end{tabular}


Figura 18. Número médio de plântulas emergidas na quarta avaliação das amostras coletadas nos tratamentos na linha da cultura, independente dos tratamentos usados na entrelinha, no período chuvoso do ano.

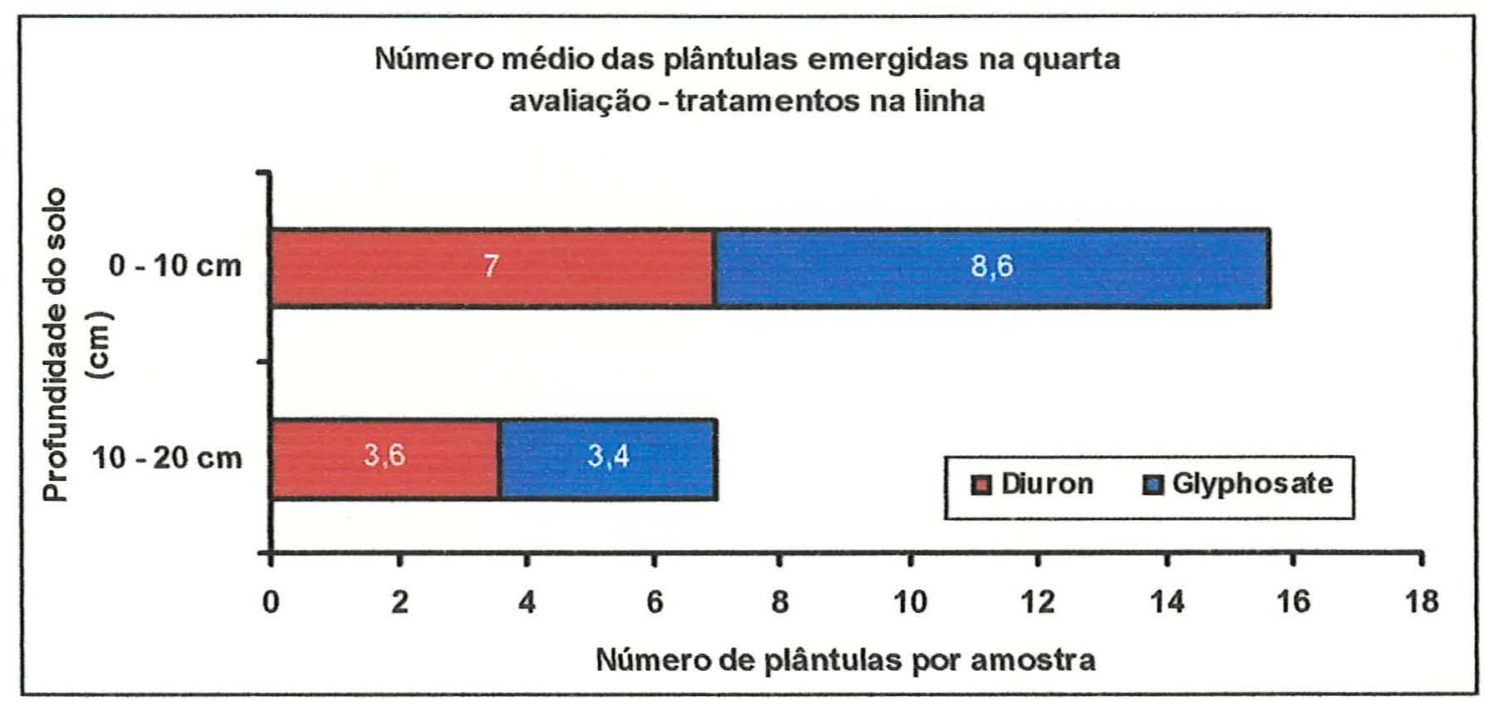

Tabela 22. Número médio de plântulas que emergiram das amostras colocadas em bandejas nos diversos tratamentos x profundidades, na linha da cultura, quarta avaliação, no período da chuva.

\begin{tabular}{|c|c|c|}
\hline \multirow[b]{2}{*}{ Tratamentos } & \multicolumn{2}{|c|}{ Diuron } \\
\hline & $0-10 \mathrm{~cm}$ & $10-20 \mathrm{~cm}$ \\
\hline Roçada & 8,4 & 3,6 \\
\hline Glyphosate & 7,1 & 4,2 \\
\hline Guandu & 6,4 & 3,7 \\
\hline Lab-lab & 7,2 & 3,3 \\
\hline Gradagem & 6,0 & 3,3 \\
\hline \multirow[t]{2}{*}{ Média } & $7,0 \mathrm{Ab}$ & $3,6 \mathrm{Ba}$ \\
\hline & \multicolumn{2}{|c|}{ Glyphosate } \\
\hline Tratamentos & $0-10 \mathrm{~cm}$ & $10-20 \mathrm{~cm}$ \\
\hline Roçada & 9,5 & 2,7 \\
\hline Glyphosate & 8,3 & 3,9 \\
\hline Guandu & 7,2 & 2,7 \\
\hline Lab-lab & 9,7 & 4,3 \\
\hline Gradagem & 8,1 & 3,4 \\
\hline Média & $8,6 \mathrm{Aa}$ & $3,4 \mathrm{Ba}$ \\
\hline
\end{tabular}

Médias seguidas por mesmas letras maiúsculas na linha e minúsculas na coluna, não diferem entre si ao nível de $5 \%$ de probabilidade pelo teste de Tukey. C.V. $\%=17,3 \%$. 


\subsection{Contagem de sementes de plantas daninhas no solo}

\subsubsection{Interação herbicida $x$ profundidade de amostragem, na linha de plantio, nas épocas chuvosa e seca do ano}

Nas Figuras 19 a 20 e Tabelas 23 a 24 estão apresentados os resultados dos números de sementes obtidos da interação herbicida $x$ profundidade na linha de plantio, para a época chuvosa e seca, respectivamente.

Analisando o efeito do herbicida diuron nas profundidades de 0-10 e 10-20 cm, observa-se que diferenças para as médias, apresentando maior número de sementes na camada mais superficial do solo.

Este efeito foi observado para as duas épocas estudadas; a mesma tendência de resultados e diferenças entre tratamentos também foi observada para o herbicida glyphosate.

Do mesmo modo, comparando-se os herbicidas, observa-se que estes apresentam médias significativamente diferentes, sendo o número de sementes formadas maior em parcelas onde foi utilizado o glyphosate.

Supõem-se que estes resultados sejam devido às características dos produtos, não havendo influência da época de coleta. Machado Neto (1985) após nove aplicações anuais de diuron, encontrou este produto apenas na camada superficial do solo $(0-5 \mathrm{~cm})$, sendo que a sua persistência ocorreu por mais de um ano.

O glyphosate quando aplicado em doses recomendadas apresenta uma rápida inativação no solo (Hensley et al.,1978). Essa rápida inativação se dá por adsorsão, seguido por degradação microbiana (Spranke, 1975). No caso em estudo, acredita-se que essa adsorsão não tenha influenciado muito no desempenho do produto, visto que, o solo onde foi instalado o experimento é 
Figura 19. Número médio de sementes obtidas das amostras coletadas nos tratamentos na linha da cultura, independente dos tratamentos usados na entrelinha, no período chuvoso do ano.

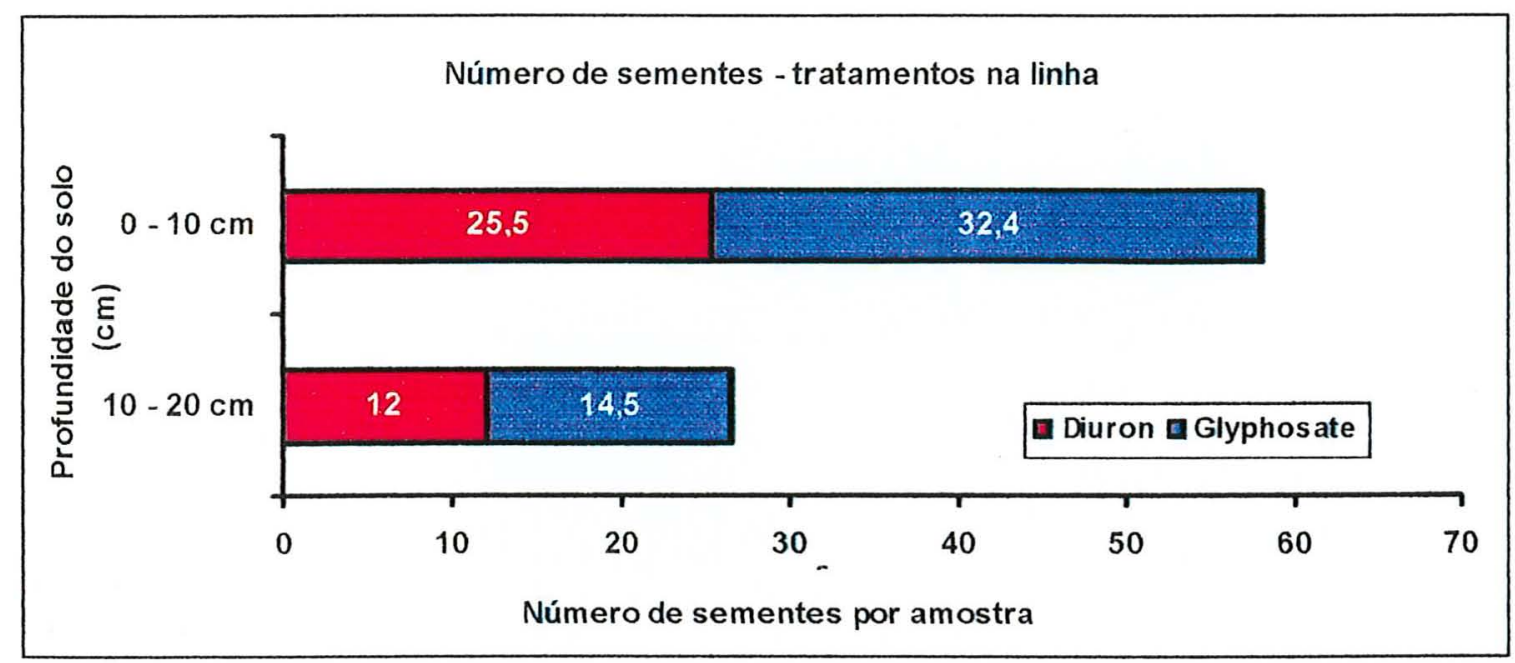

Tabela 23. Número de sementes por amostras da interação herbicida x profundidade, na linha de plantio, no período chuvoso do ano.

\begin{tabular}{lcc}
\hline & & Diuron \\
\cline { 2 - 3 } Tratamentos & $0-10 \mathrm{~cm}$ & $10-20 \mathrm{~cm}$ \\
\hline Roçada & 28,4 & 11,6 \\
Glyphosate & 28,2 & 11,9 \\
Guandu & 28,3 & 11,5 \\
Lab-lab & 28,2 & 12,0 \\
Gradagem & 28,1 & 11,90 \\
\hline Média & $28,2 \mathrm{Ab}$ & $11,9 \mathrm{Bb}$ \\
\hline & & \\
Tratamentos & $0-10 \mathrm{~cm}$ & $10-20 \mathrm{~cm}$ \\
\hline Roçada & 35,4 & 14,8 \\
Glyphosate & 35,3 & 14,4 \\
Guandu & 35,2 & 14,3 \\
Lab-lab & 35,1 & 14,4 \\
Gradagem & 35,6 & 15,2 \\
\hline Média & $35,3 \mathrm{Aa}$ & $14,6 \mathrm{Ba}$
\end{tabular}

Médias seguidas por mesmas letras maiúsculas na linha e minúsculas na coluna, não diferem entre si ao nível de $5 \%$ de probabilidade pelo teste de Tukey. C.V. $\%=10,0 \%$. 
Figura 20. Número médio de sementes obtidas das amostras coletadas nos tratamentos na linha da cultura, independente dos tratamentos usados na entrelinha, no período seco do ano.

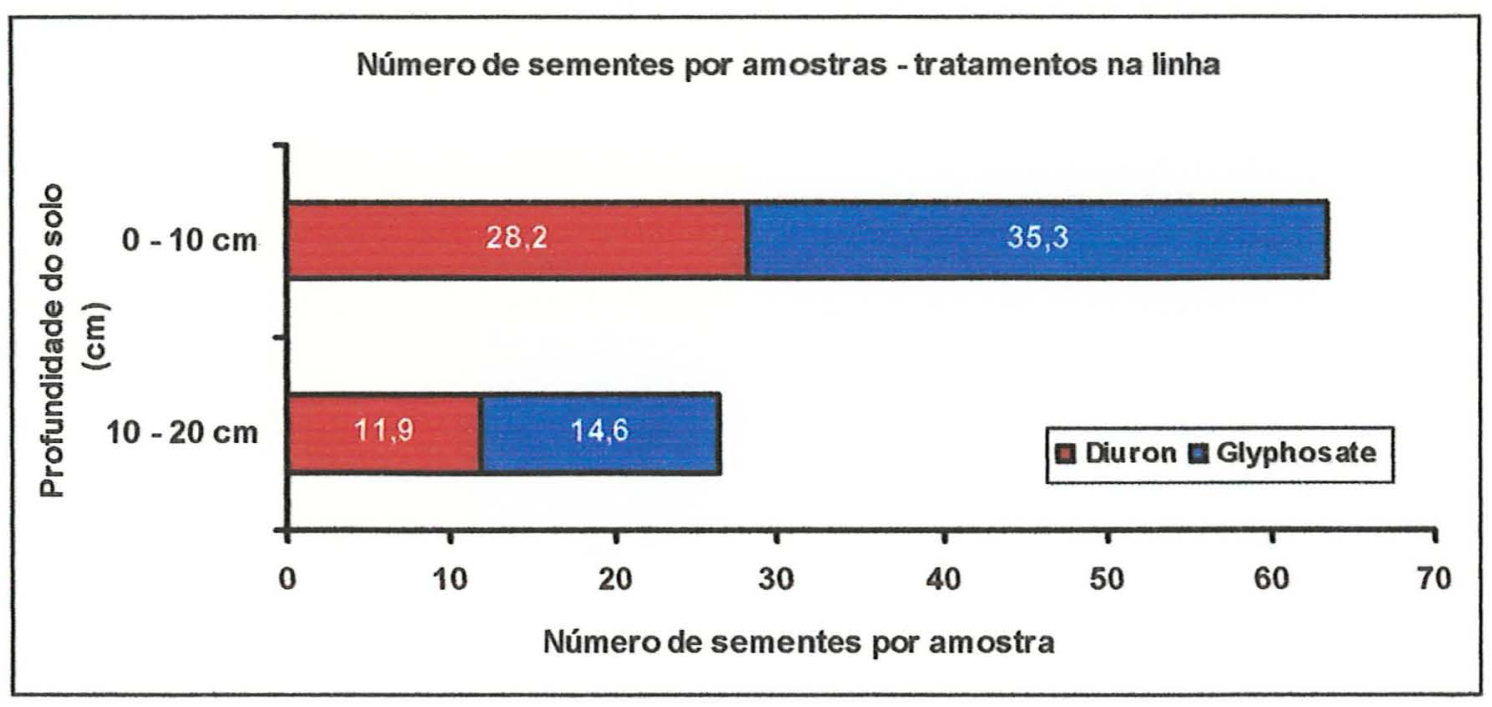

Tabela 24. Número de sementes por amostras da interação herbicida $x$ profundidade, na linha de plantio, no período seco do ano.

\begin{tabular}{lcc}
\hline & \multicolumn{2}{c}{ Diuron } \\
\cline { 2 - 3 } Tratamentos & $0-10 \mathrm{~cm}$ & $10-20 \mathrm{~cm}$ \\
\hline Roçada & 25,5 & 11,3 \\
Glyphosate & 24,9 & 12,6 \\
Guandu & 26,7 & 11,3 \\
Lab-lab & 25,7 & 12,4 \\
Gradagem & 24,9 & 12,6 \\
\hline Média & $25,5 \mathrm{Ab}$ & $12,0 \mathrm{Bb}$ \\
\hline & & \\
Tratamentos & $0-10 \mathrm{~cm}$ & Glyphosate \\
\hline Roçada & 31,5 & $10-20 \mathrm{~cm}$ \\
Glyphosate & 33,3 & 13,9 \\
Guandu & 31,7 & 14,8 \\
Lab-lab & 32,7 & 14,5 \\
Gradagem & 32,7 & 14,5 \\
\hline Média & $32,4 \mathrm{Aa}$ & 14,7 \\
\hline
\end{tabular}

Médias seguidas por mesmas letras maiúsculas na linha e minúsculas na coluna, não diferem entre si ao nível de $1 \%$ de probabilidade pelo teste de Tukey. C.V. $\%=3,8 \%$. 
segundo Vidal-Torrado \& Sparovek (1993) areno argiloso, portanto todo o glyphosate que atingiu o solo nas parcelas foi adsorvido imediatamente pelas partículas coloidais, não havendo portanto efeito residual do herbicida.

\subsection{Caracterização do Banco de Sementes}

\subsubsection{Espécies daninhas presentes}

As espécies de plantas daninhas que foram encontradas no estudo, seja pelo método de germinação ou pela separação de sementes, encontramse listadas por ordem de família, no APÉNDICE 1.

A maioria das espécies encontradas são anuais, excetuando-se algumas como o Gomphrena celosioides Mart., Cyperus ferax (L.) Rich, Cyperus rotundus (L.), Digitaria insularis (L.) Fedd., Panicum maximum Jacq., Commmelina benghalensis (L.) e Sida sp.

\subsubsection{Dinâmica populacional e freqüência das espécies na entrelinha, para emergência em bandeja}

Nas Figuras 21a-b até $30 a-b$, estão apresentadas as variações na estrutura da vegetação daninha bem como as suas freqüências dentro de cada tratamento e nos dois periodos estudados, chuvoso e seco.

Observa-se que os tratamentos com implementos mecânicos apresentaram maior número de espécies, sendo 18 e 16 (Figuras 21 a-b e22 ab) para roçada e 20 para gradagem (Figura 29a-b e 30 a-b). Como o número de espécies nessas é maior, as freqüências das espécies presentes são contudo menores.

Com relação às gramíneas, nota-se que das seis espécies presentes, somente a $D$. horizontalis Willd. ocorreu nas duas épocas de amostragem; a D. insularis (L.) Fedd. e S. geniculata (Lam.) Beav. somente foram encontrados na época da chuva, e o $P$. maximum Jacq. e Rhynchelytrum repens (Willd) C. E. Hubb., estiveram presentes somente na época seca. Para as cyperaceas, o C. ferax (L.) Rich. esteve presente nas duas épocas, 
Figura21a. Frequência (\%) das espécies daninhas na entrelinha de plantio, roçada/diuron no período chuvoso

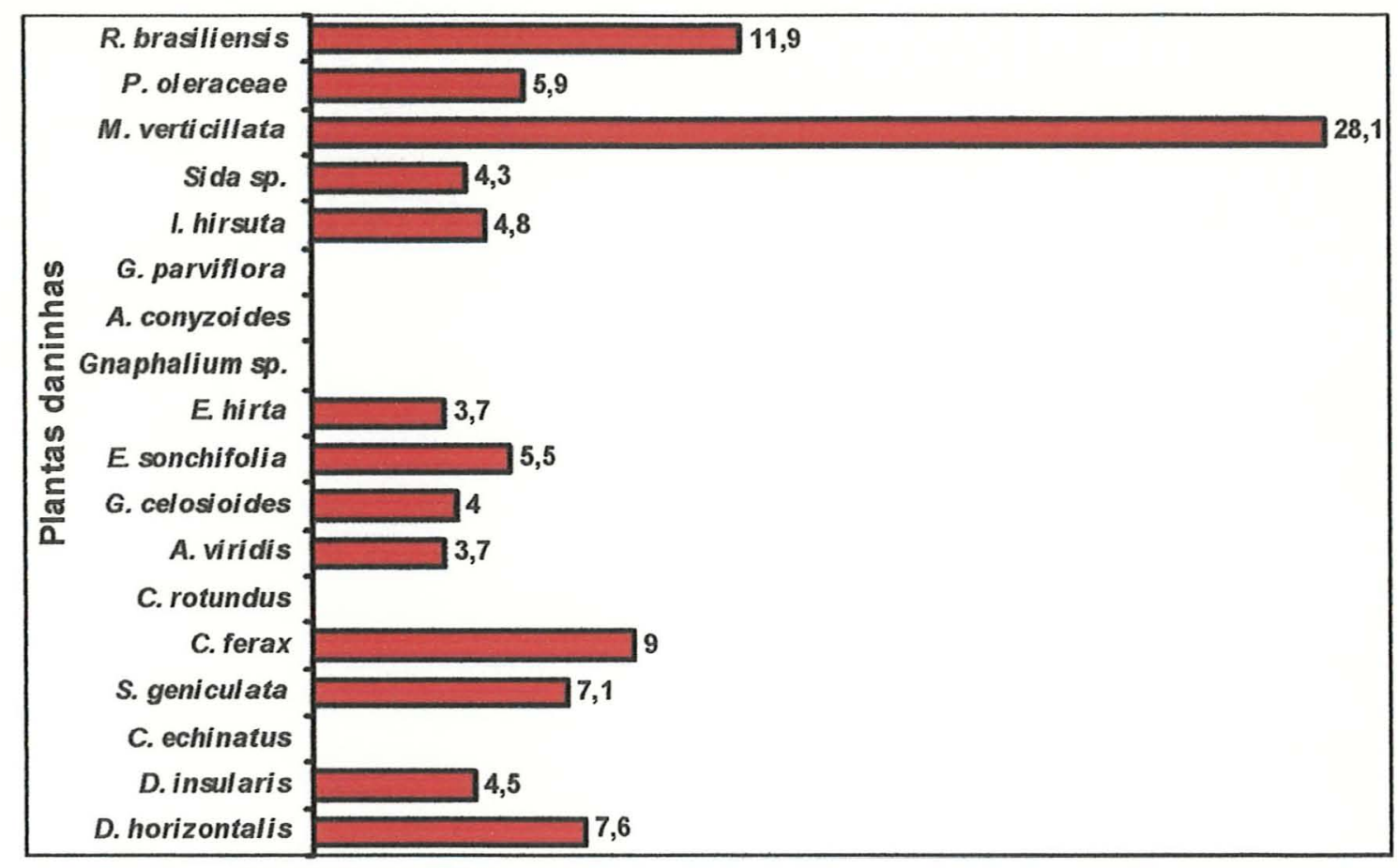

Figura21b. Frequência (\%) das espécies daninhas na entrelinha de plantio, roçada/diuron no período chuvoso

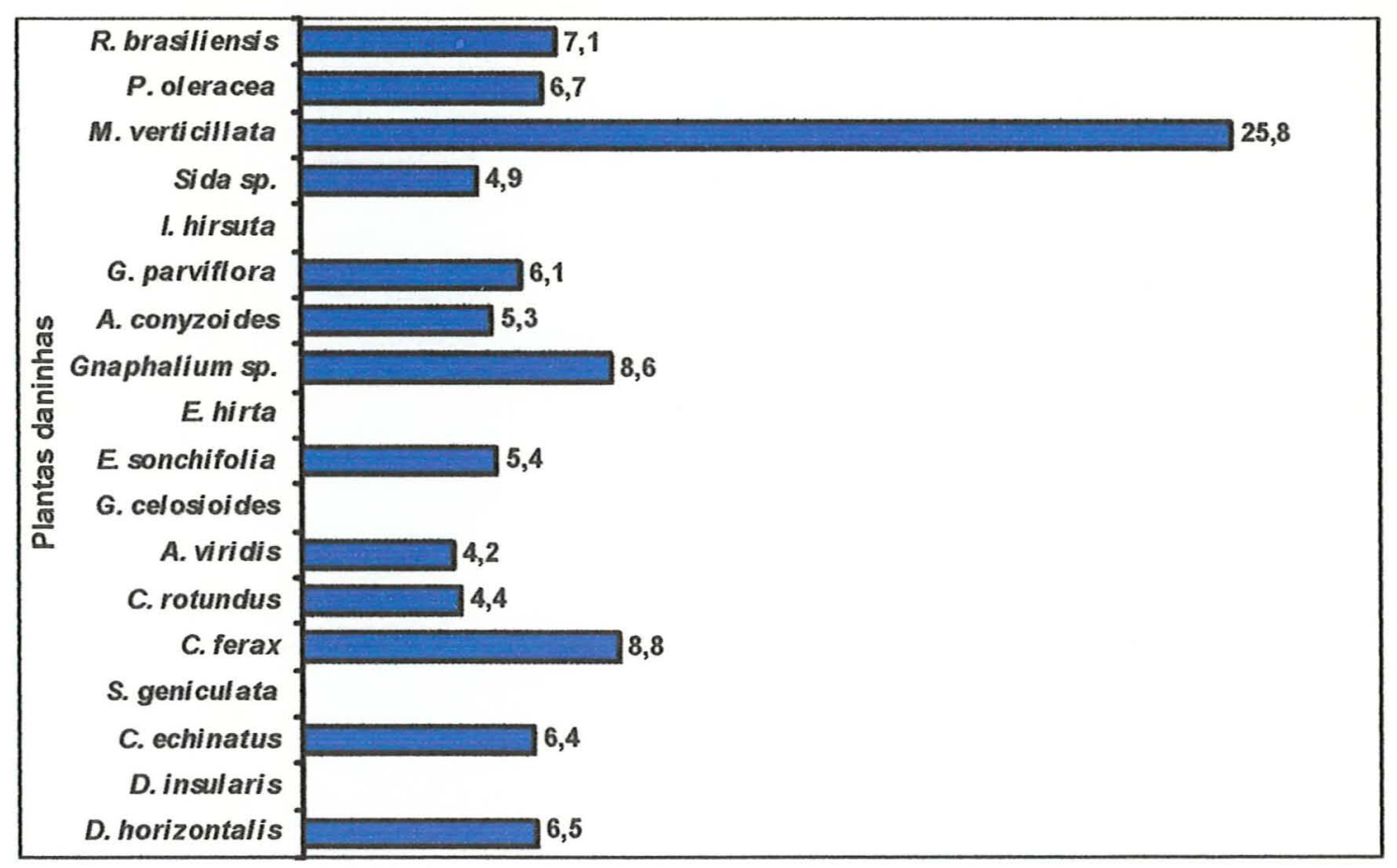


Figura22a. Frequência (\%) das espécies daninhas na entrelinha de plantio, roçada/glyphosate no período chuvoso

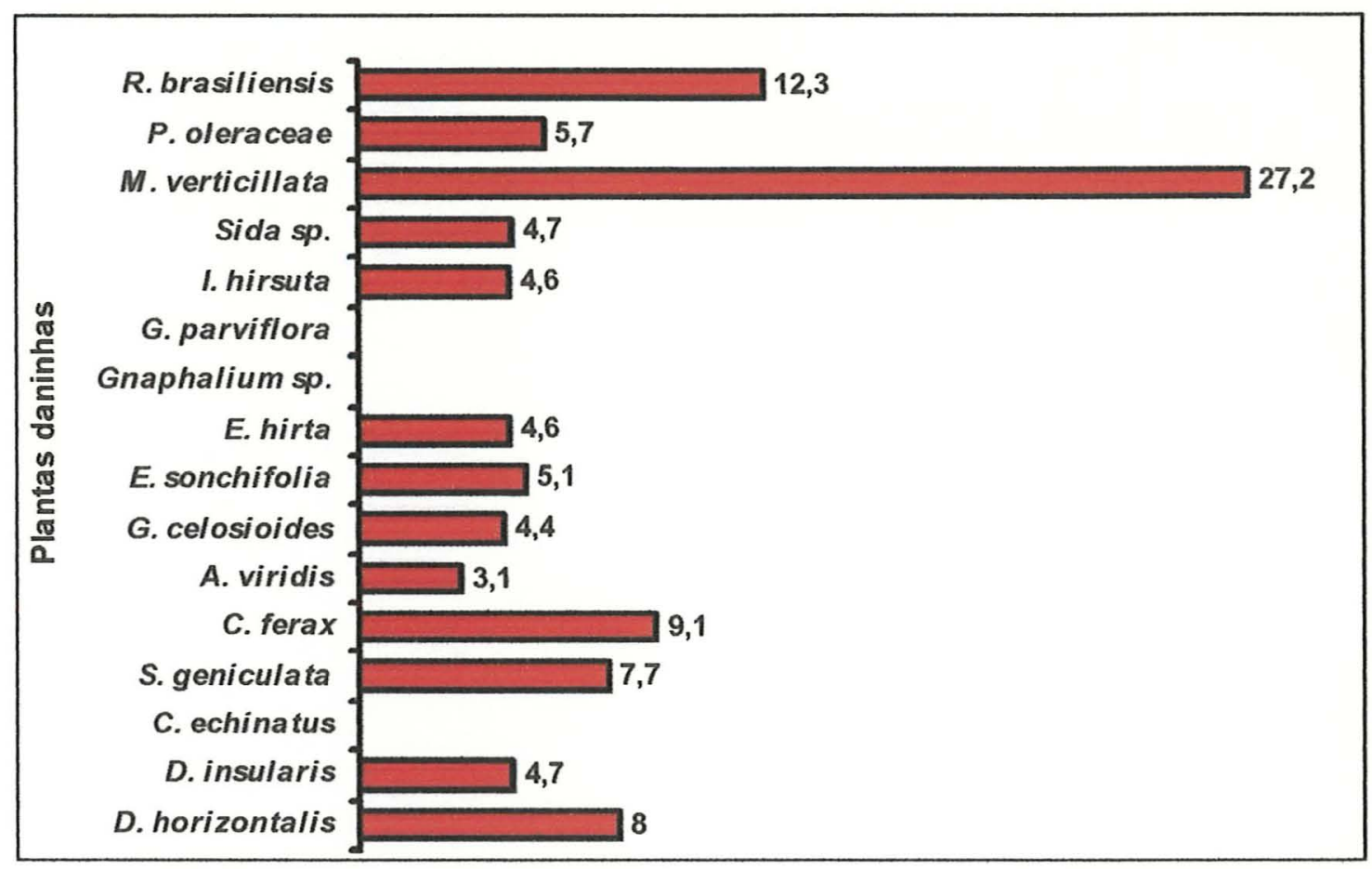

Figura22b. Frequência (\%) das espécies daninhas na entrelinha de plantio, roçada/glyphosate no período seco

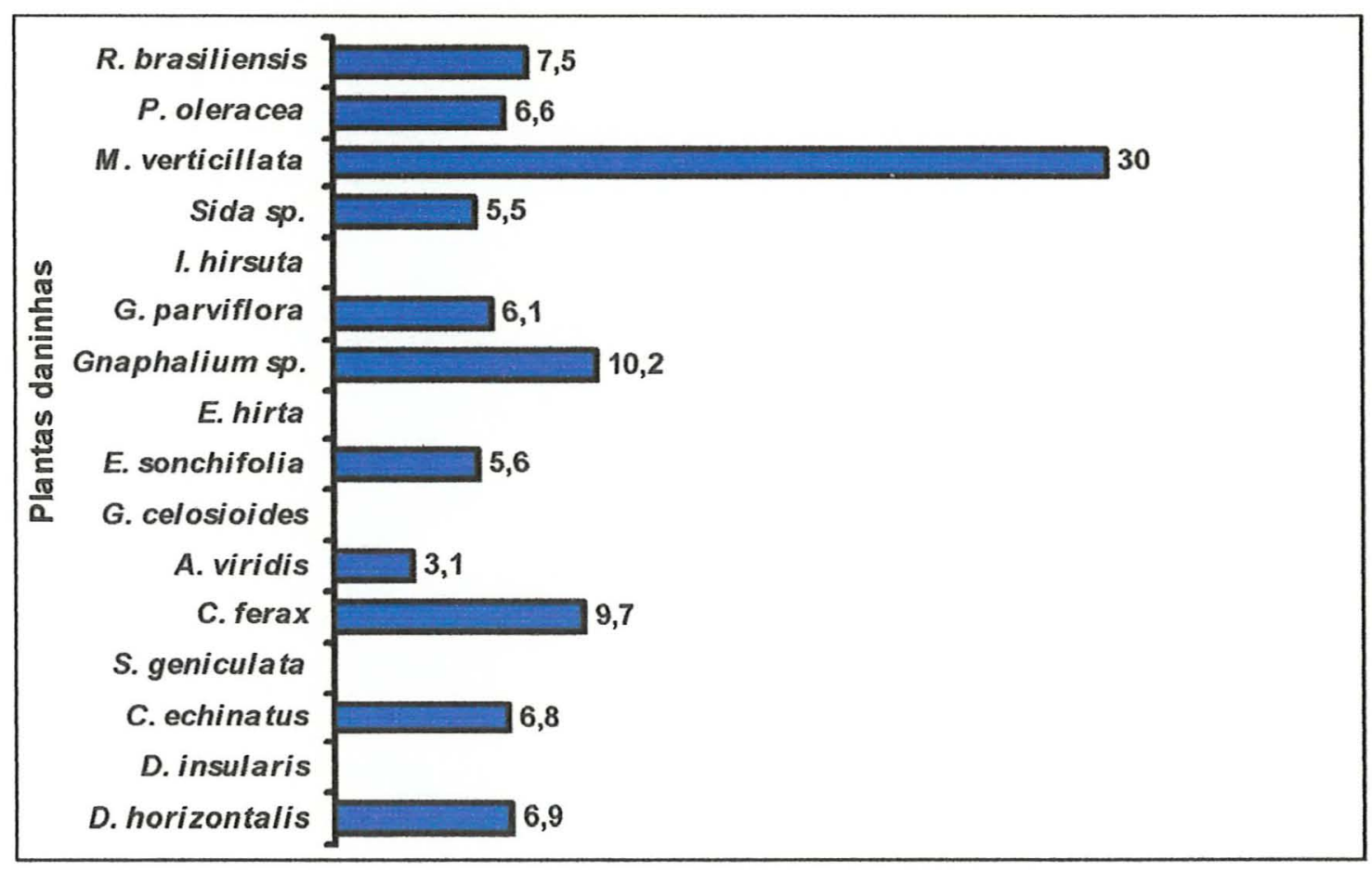


Figura 23a Freqüência (\%) das espécies daninhas na entrelinha de plantio, glyfosate/diuron no período chuvoso

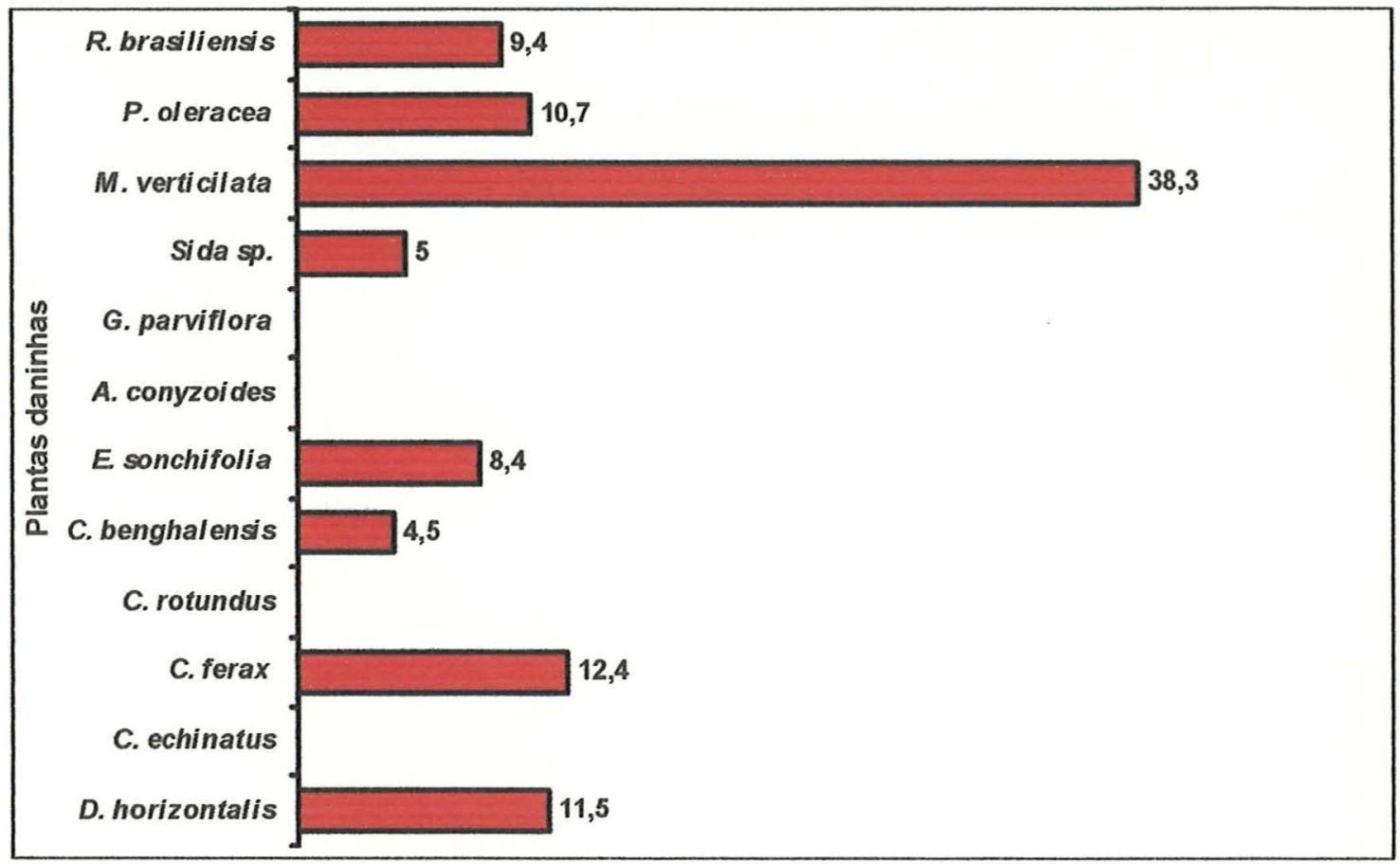

Figura 23b Freqüência (\%) das espécies daninhas na entrelinha de plantio, glyfosate/diuron no período seco

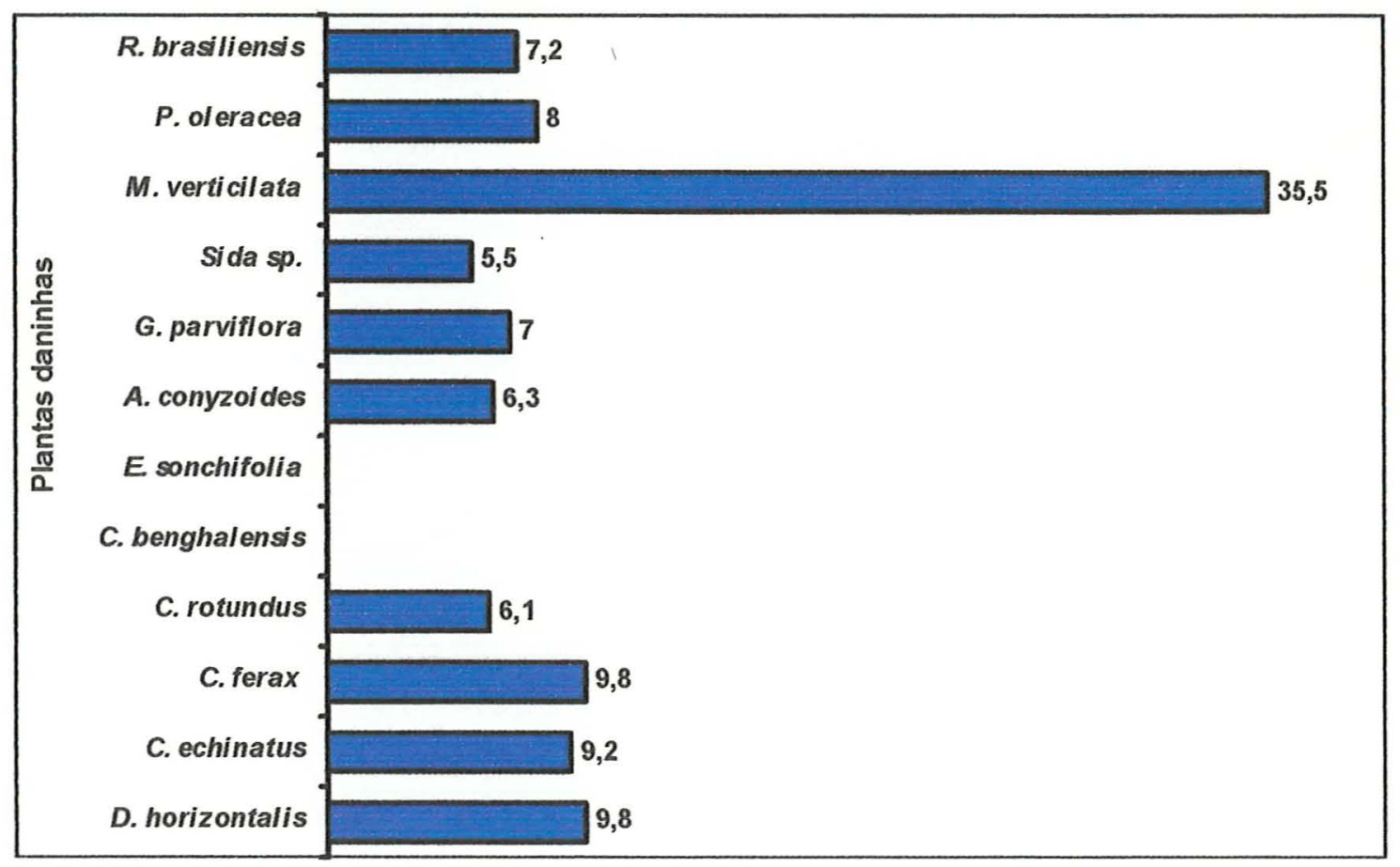


Figura 24a Frequência (\%) das espécies daninhas na entrelinha de plantio, glyphosate/glyphosate no período chuvoso

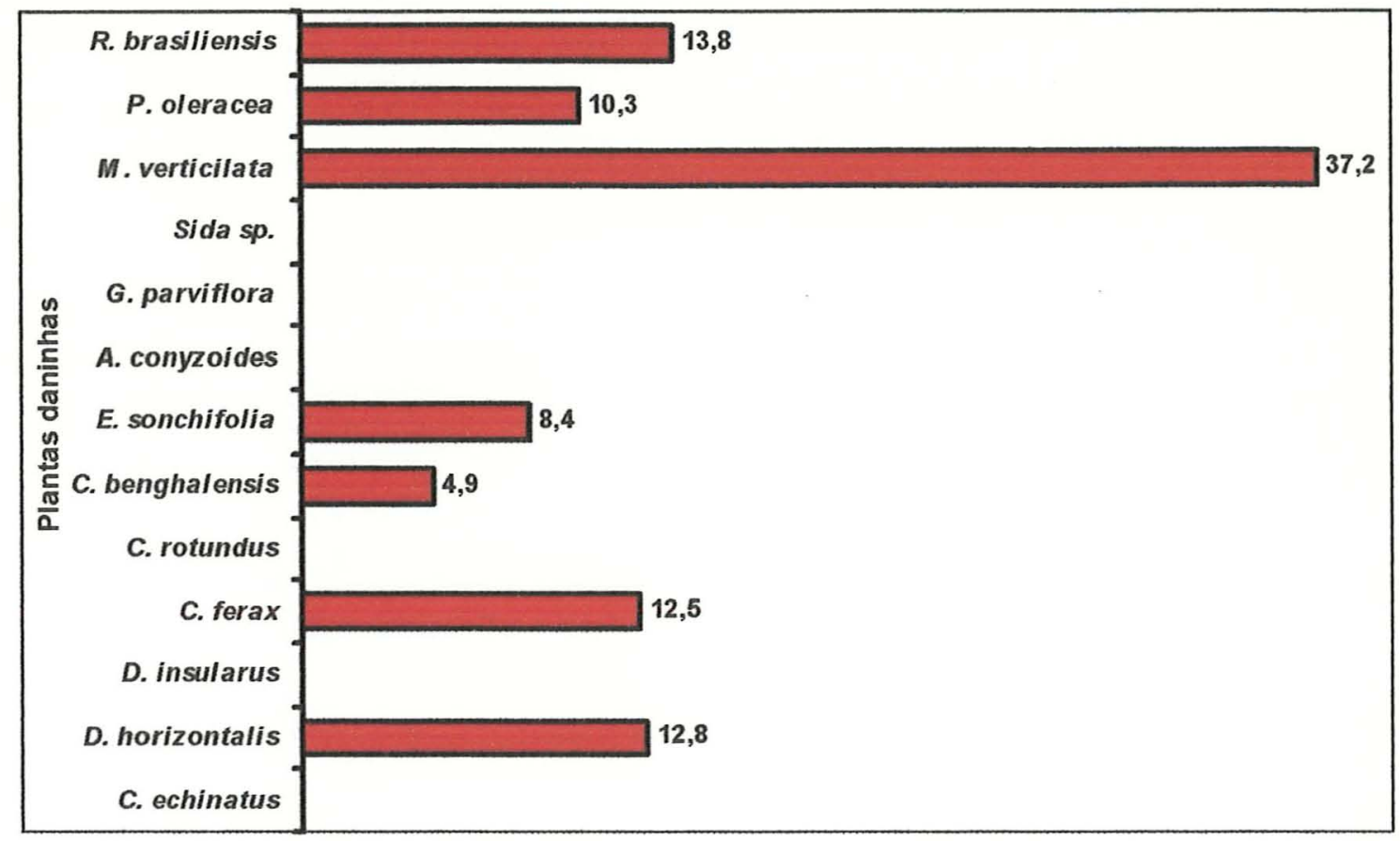

Figura 24b Frequência (\%) das espécies daninhas na entrelinha de plantio, glyphosate/glyphosate no período seco

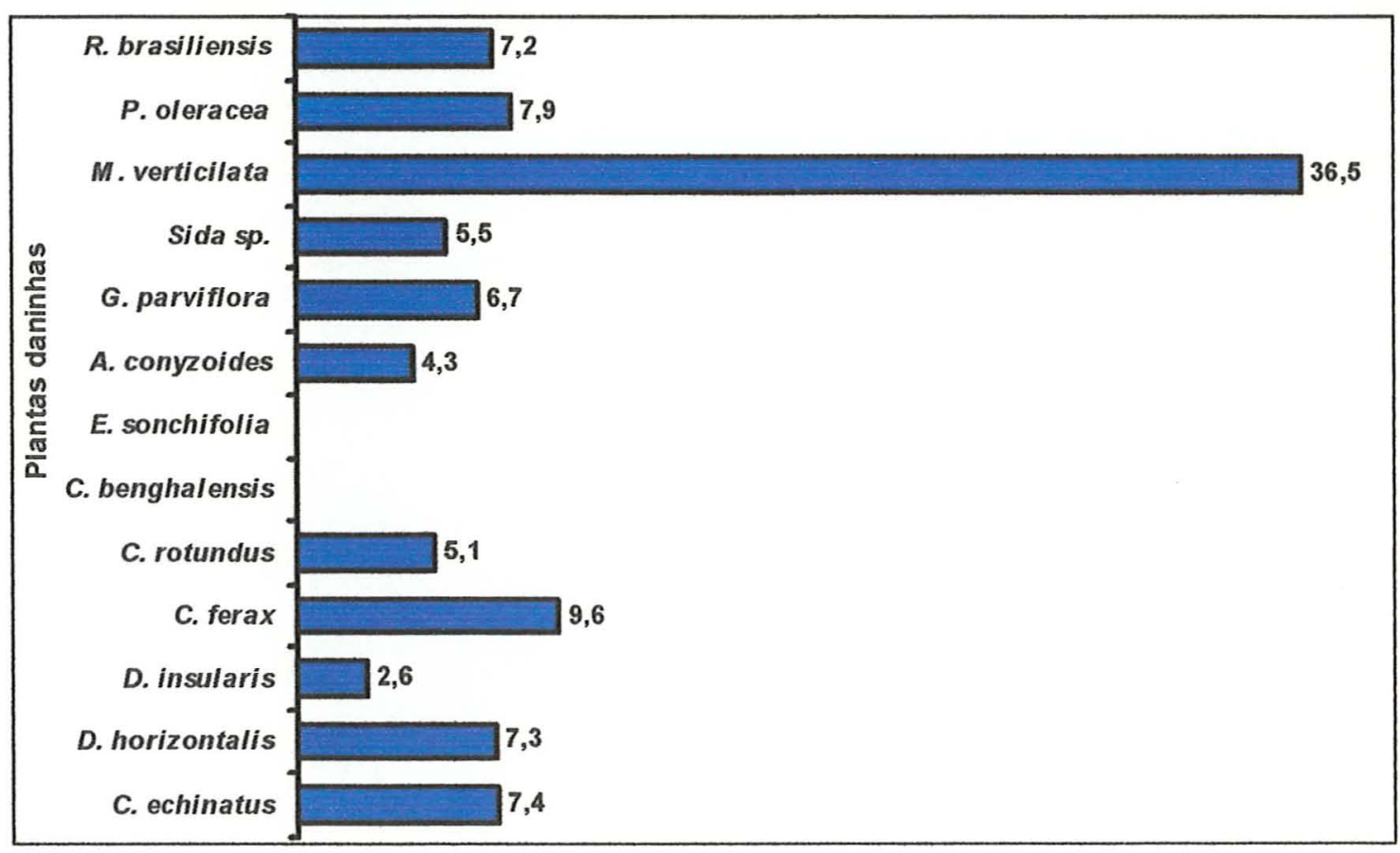


Figura 25a Frequência (\%) das espécies daninhas na entrelinha de plantio, guandu/diuron no período chuvoso

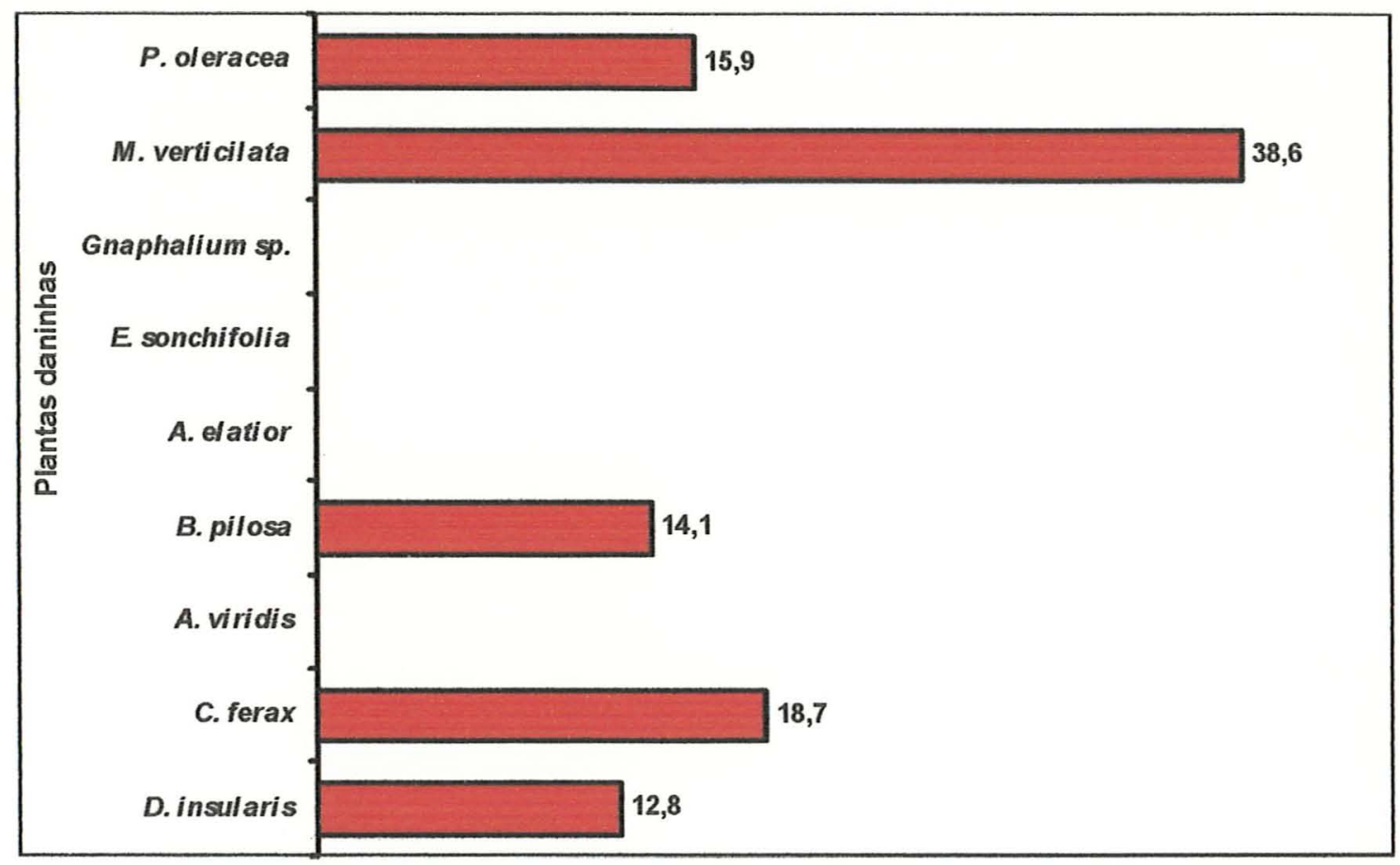

Figura 25b Frequência (\%) das espécies daninhas na entrelinha de plantio, guandu/diuron no período seco

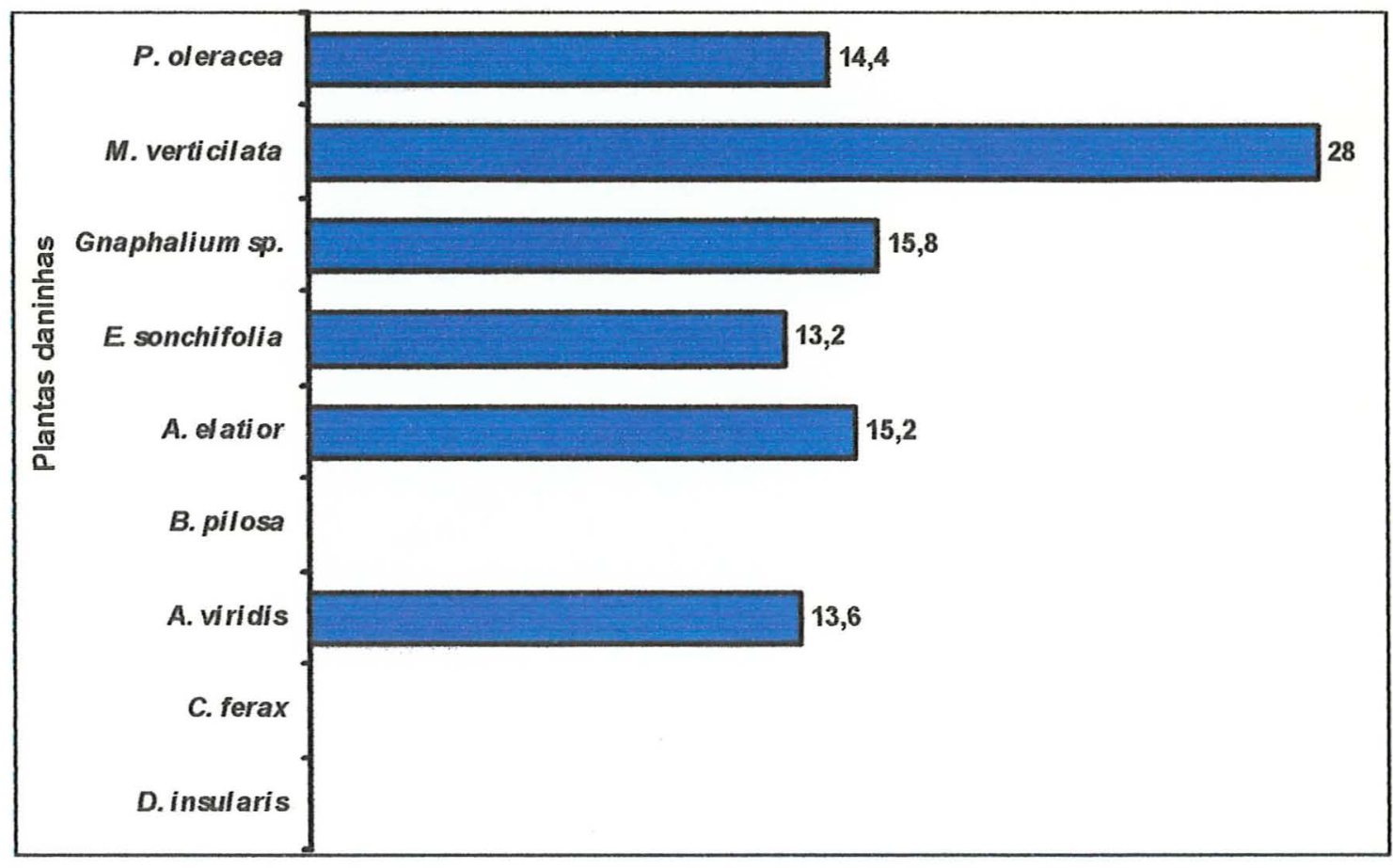


Figura 26a Frequência (\%) das espécies daninhas na entrelinha de plantio, guandu/glyphosate no período chuvoso

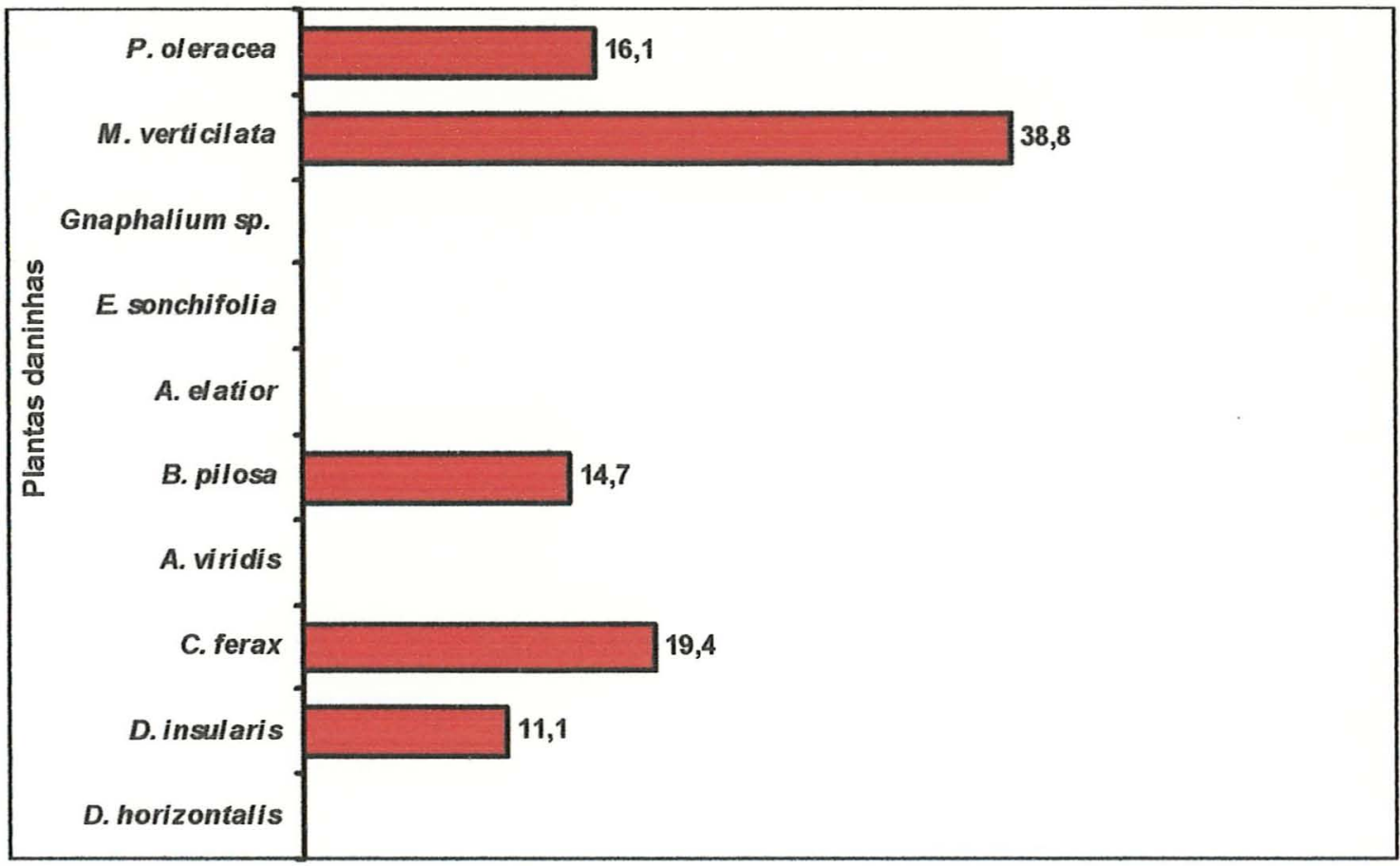

Figura 26b Frequência (\%) das espécies daninhas na entrelinha de plantio, guandu/glyphosate no período seco

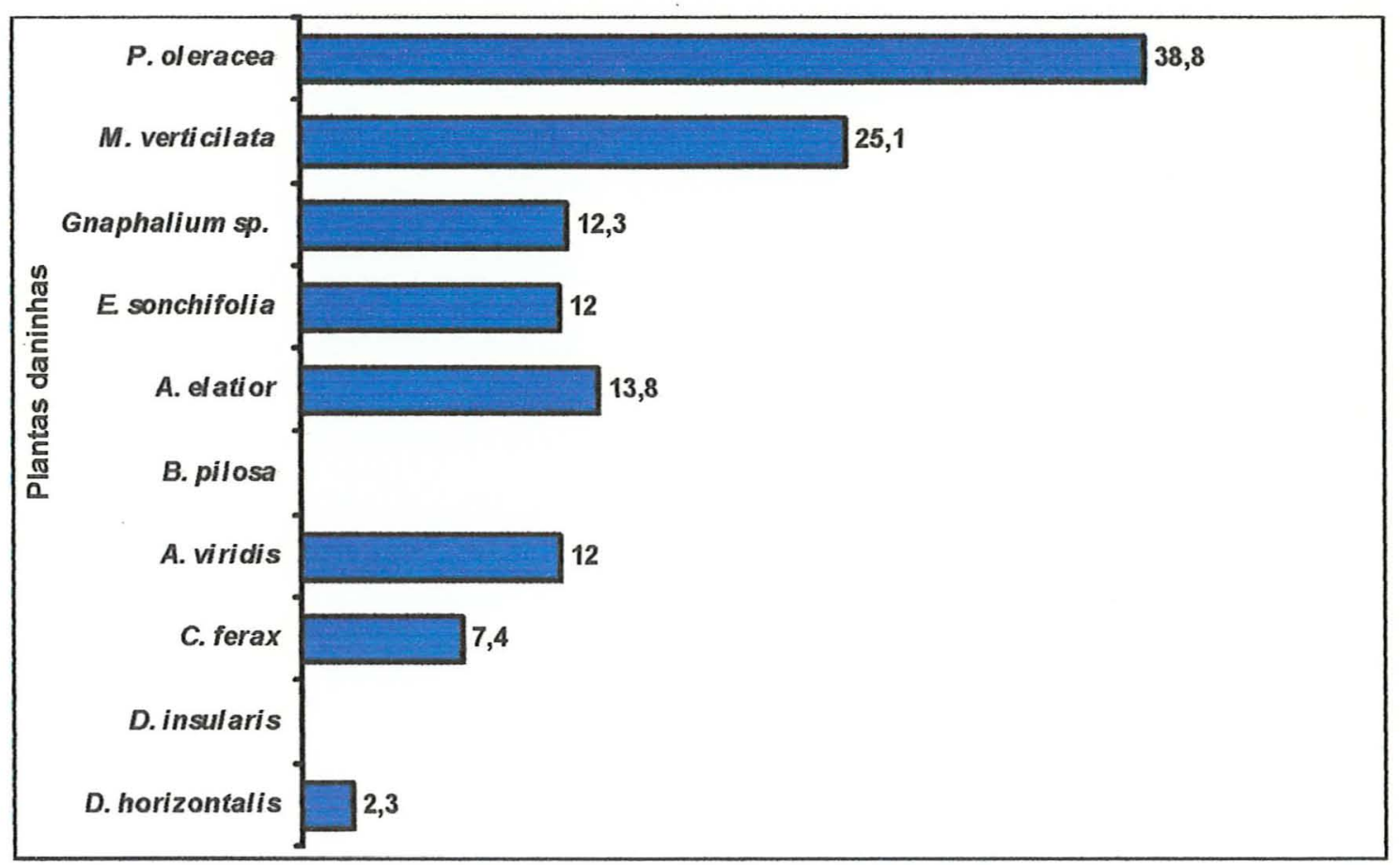


enquanto que o $C$. rotundus foi encontrado na época seca e com pequena freqüência.

Analisando as espécies dicotiledôneas, foram observadas nove famílias e treze espécies. Para as malvaceas, o gênero Sida não foi classificado, visto a dificuldade de distinguir-se as espécies presentes.

Nesse grupo de plantas, observa-se que as espécies Euphorbia hirta (L.) e Indigofera hirsuta (L.) foram encontradas somente nos tratamentos de roçada; Bidens pilosa ( $L$.) foi encontrada somente na época da chuva, enquanto que Galinsoga parviflora Cav., Gnaphalium sp. e Solanum americanum Mill., ocorreram no periodo seco. S. americanum é uma espécie freqüente em culturas perenes, produz uma grande quantidade de sementes que podem germinar após à maturação, ou podem permanecer dormentes no solo. Acredita-se que os tratamentos mecânicos utilizados tenham colocados as sementes dessa espécie mais exposta a fatores promotores da germinação.

Deve-se ressaltar a grande freqüência $(21,3 \%$ a $30,0 \%)$ de Mollugo verticillata (L.) nesses tratamentos mecânicos. $\dot{E}$ importante salientar que em análises da flora da superfície esta espécie não foi encontrada (APÊNDICE 2). Segundo Lorenzi (1982), a $M$. verticillata apresenta ciclo vegetativo curto, vegetando indistintamente durante todo o ano; então, acredita-se que a alta freqüência dessa espécie nos diferentes tratamentos realizados no experimento podem ser explicados por essas características da espécie. Freitas (1990), obteve no banco de sementes uma grande proporção de Ageratum conyzoides, mesmo quando está espécie não foi encontrada em levantamentos anteriores da flora . O autor sugere que a existência de sementes enterradas no solo propiciou o aparecimento dessa espécie em meses posteriores.

Nota-se que os tratamentos de entrelinha apresentaram geralmente a mesma estrutura populacional, ou seja, eles produziram as mesmas ou a maior parte de espécies tanto para as parcelas onde usou-se o herbicida diuron como na de glyphosate, na linha de plantio. 
Figura 27a Frequência (\%) das espécies daninhas na entrelinha de plantio, lablab/diuron no período chuvoso

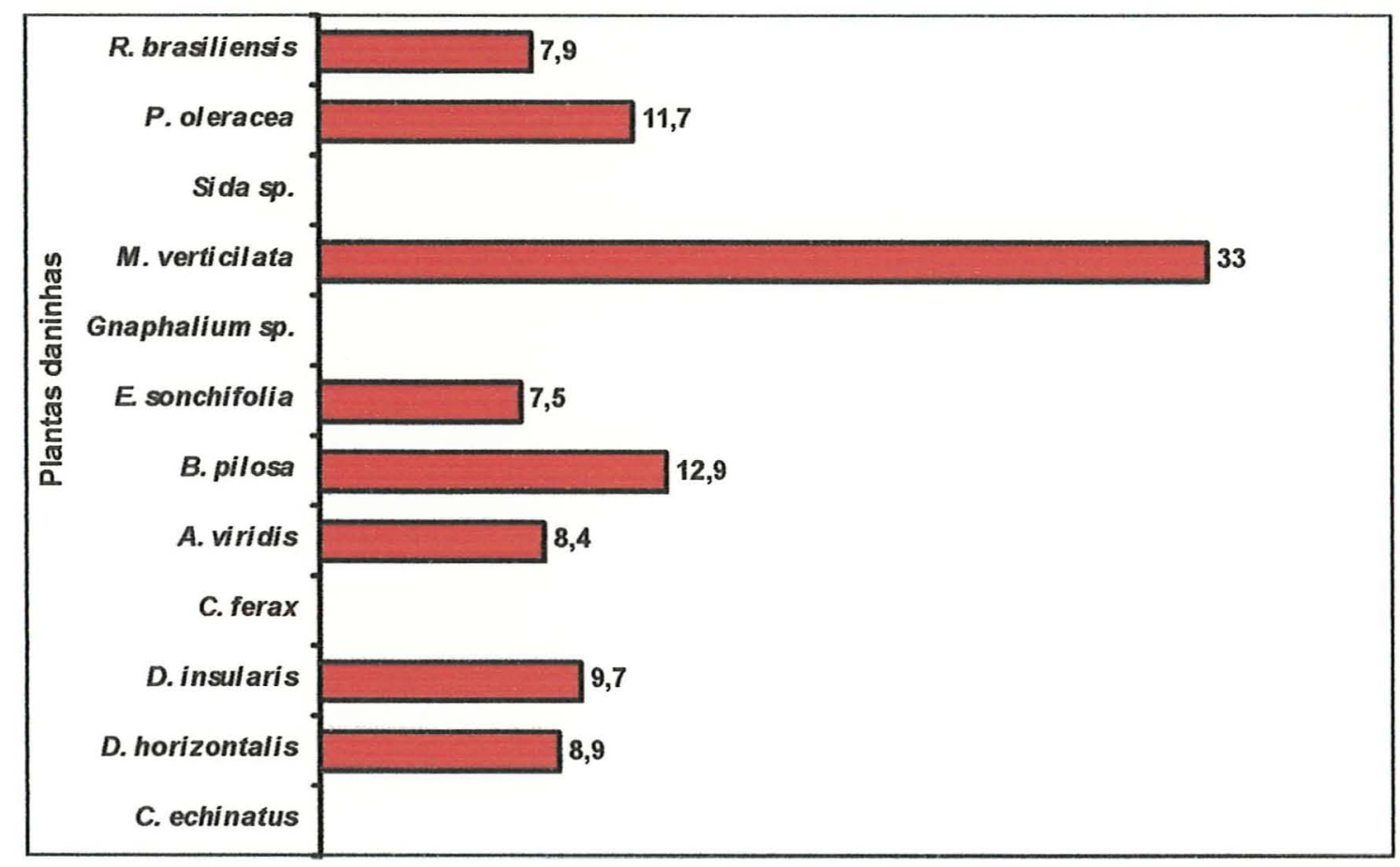

Figura 27b Frequência (\%) das espécies daninhas na entrelinha de plantio, lablab/diuron no período seco

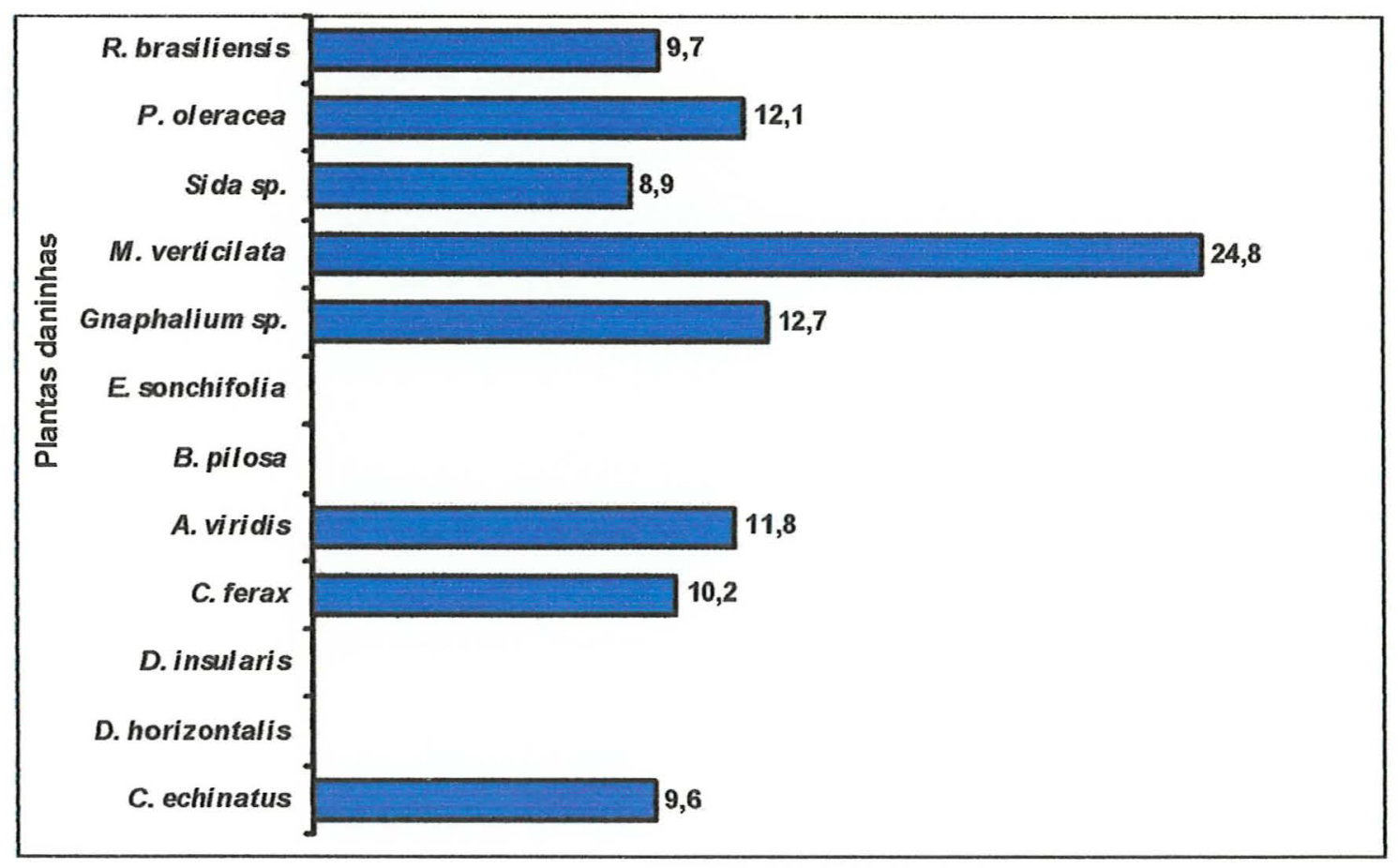


Figura 28a Frequência (\%) das espécies daninhas na entrelinha de plantio, lablab/glyphosate no período chuvoso

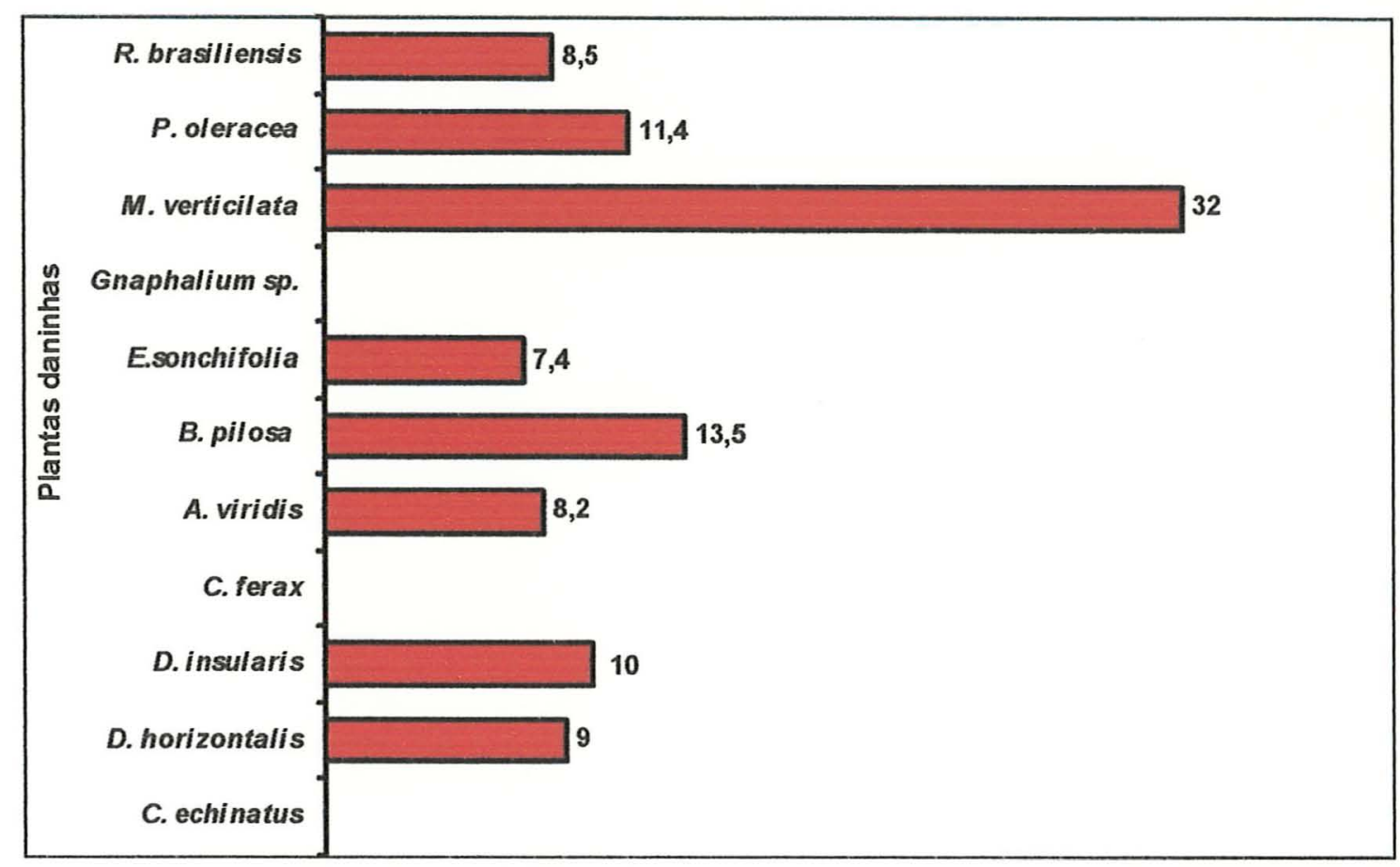

Figura 28b Frequência (\%) das espécies daninhas na entrelinha de plantio, lablab/glyphosate no período seco

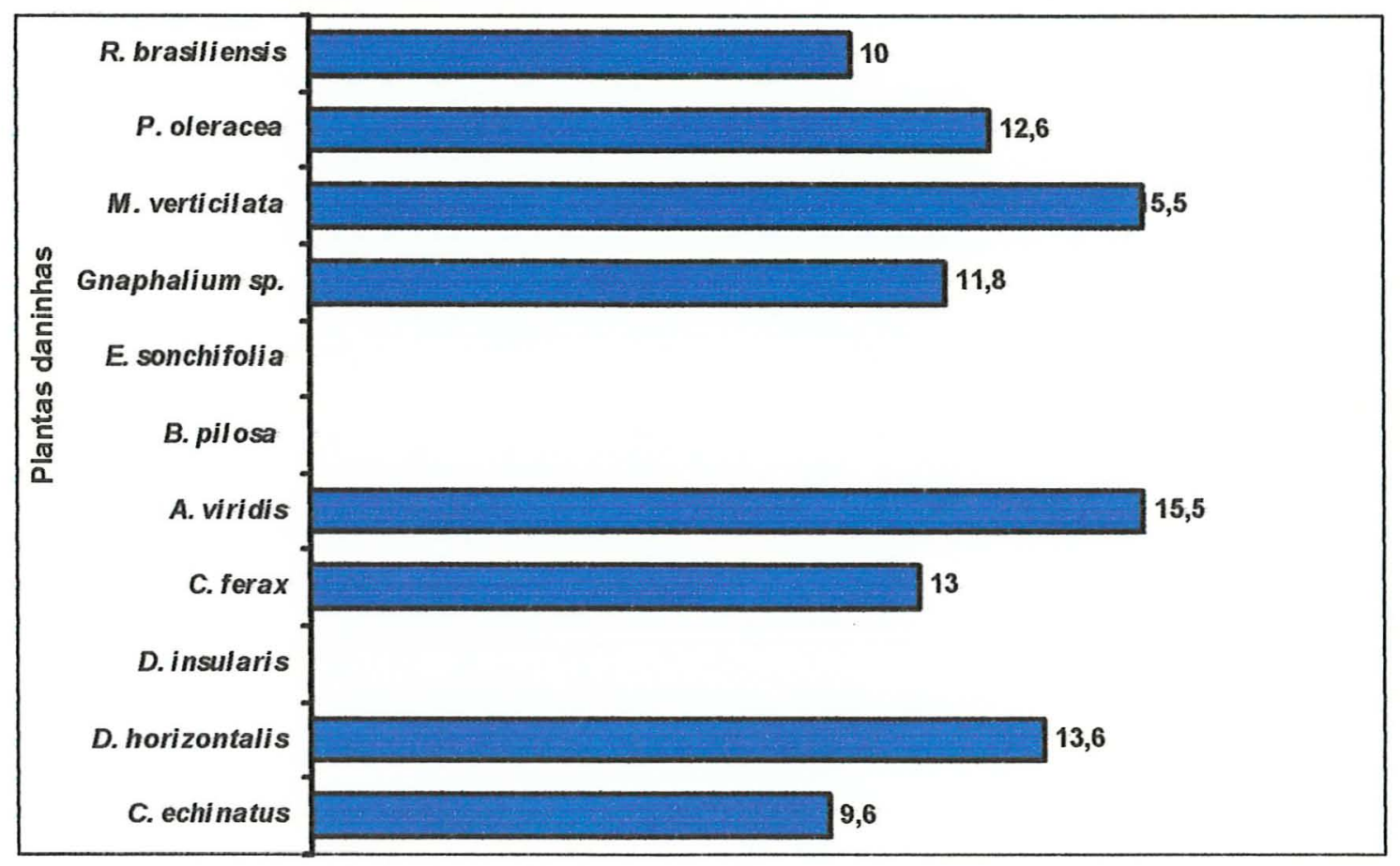


Figura 29a Freqüência (\%) das espécies daninhas na entrelinha de plantio, gradagem/diuron no período chuvoso

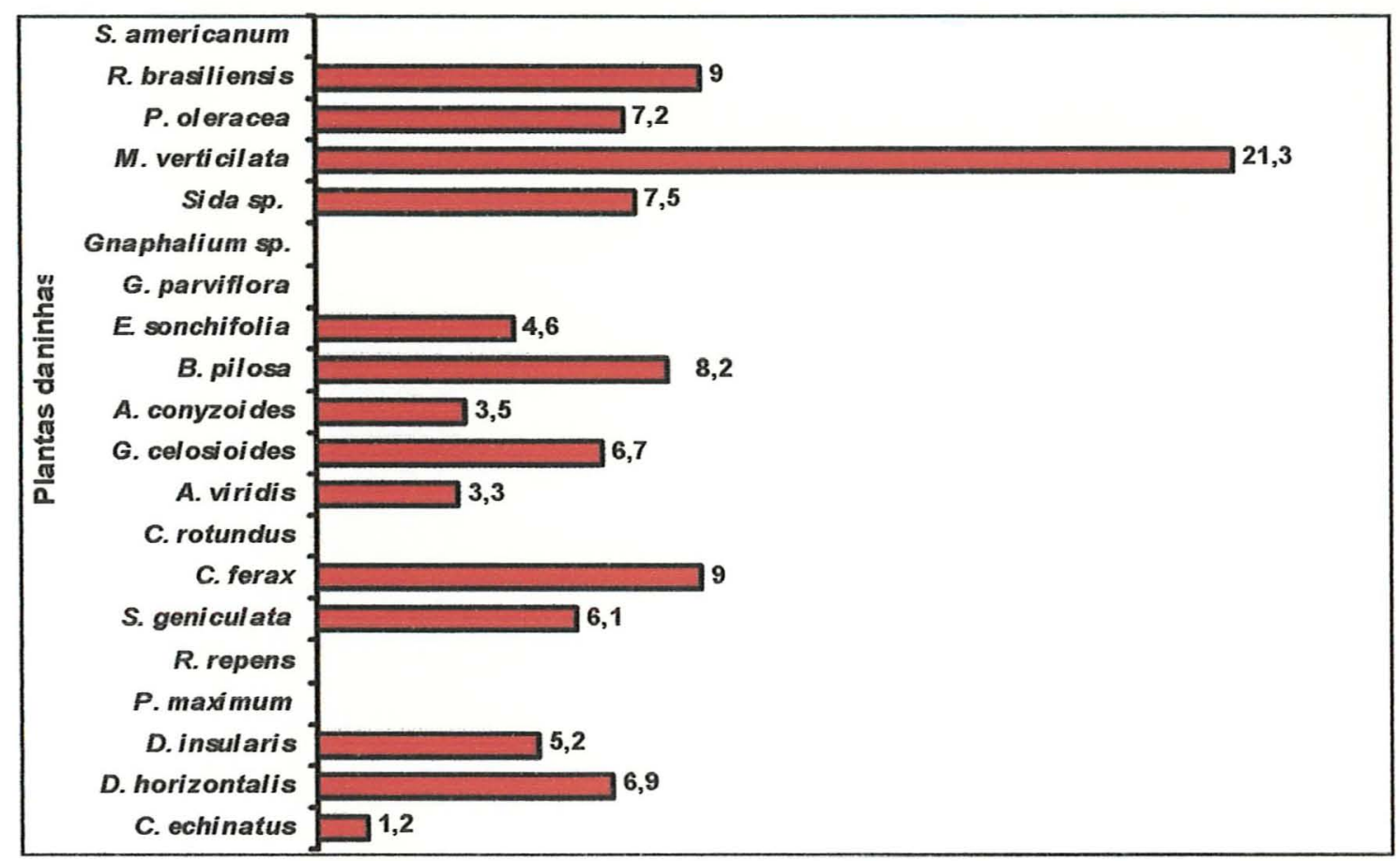

Figura 29b Frequência (\%) das espécies daninhas na entrelinha de plantio, gradagem/diuron no período seco

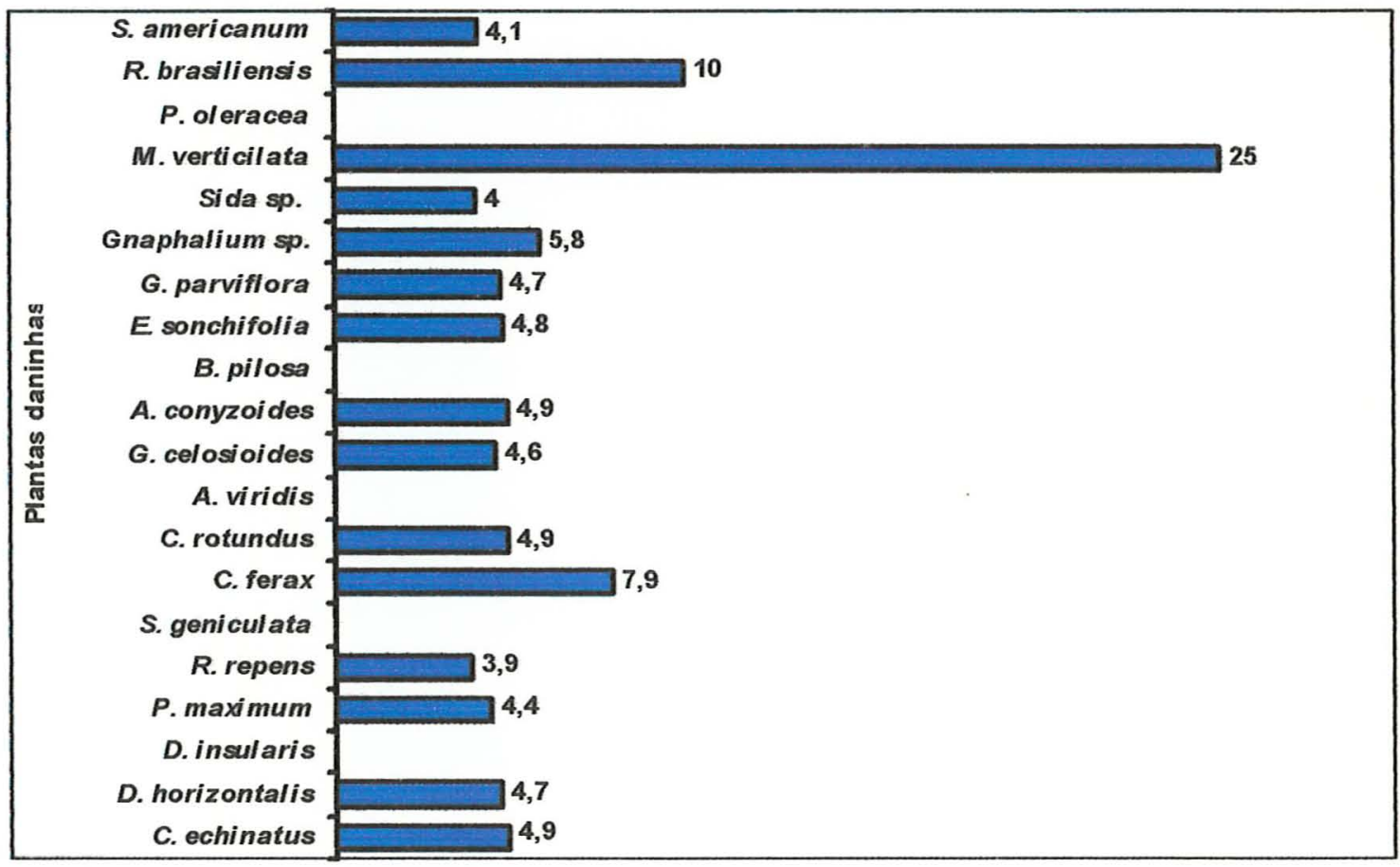


Figura 30a Frequência (\%) das espécies daninhas na entrelinha de plantio, roçada/diuron no período chuvoso

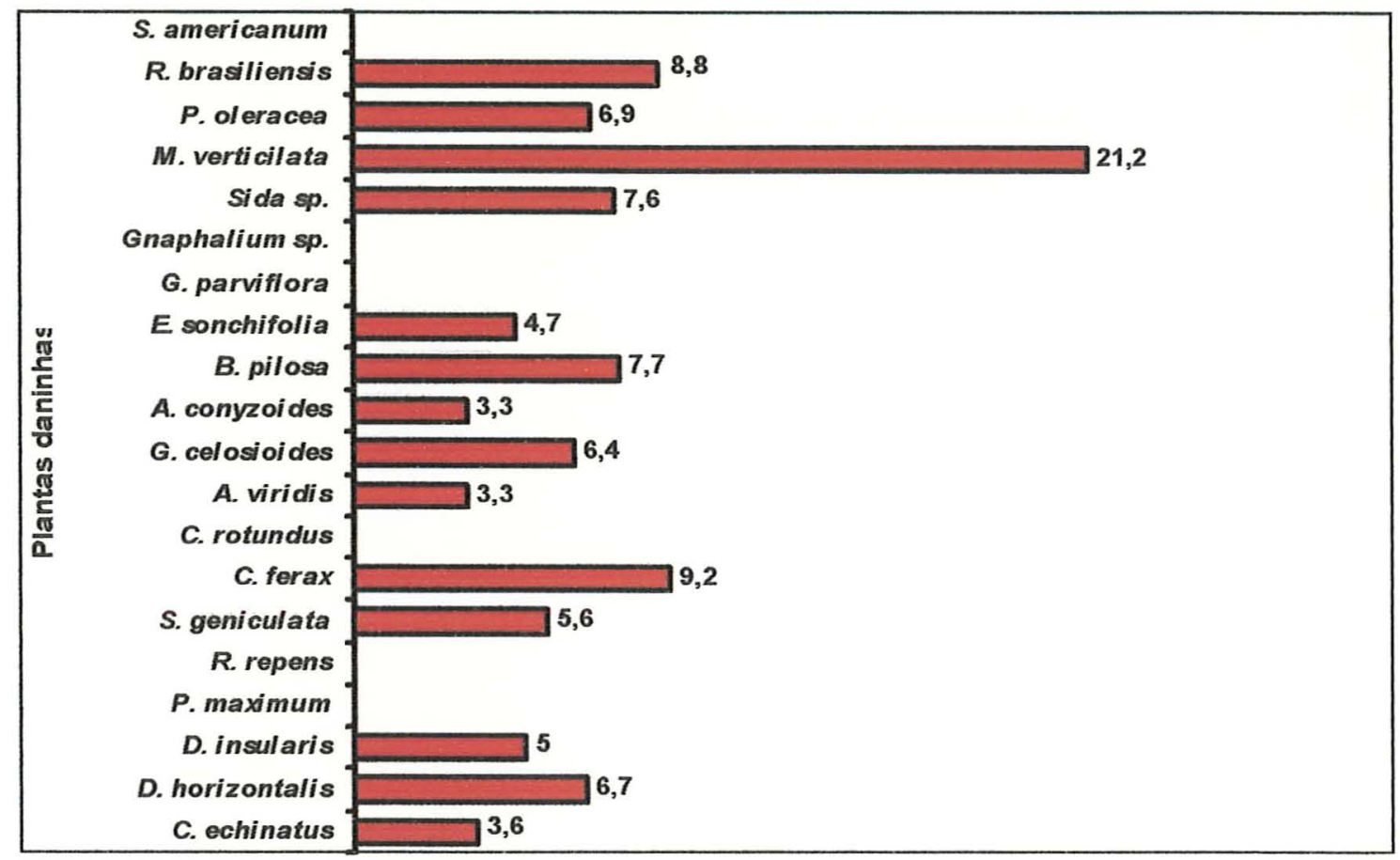

Figura 30b Frequência (\%) das espécies daninhas na entrelinha de plantio, roçada/diuron no período seco

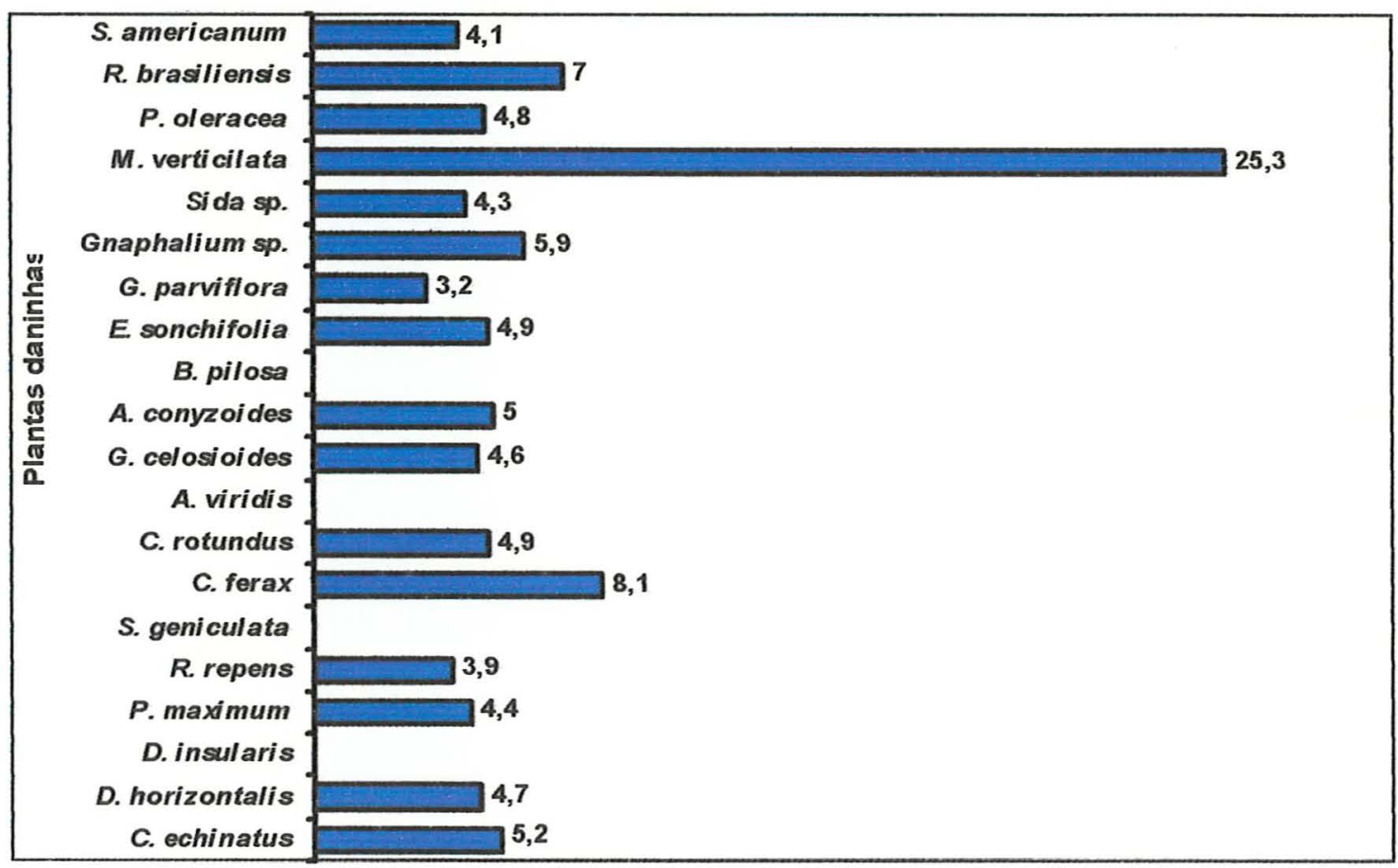


Blanco \& Blanco (1991) observaram que o manejo de planta daninhas através de movimentação do solo por cultivo com enxada rotativa, estimulou a emergência de espécies como $B$. pilosa, $A$. viridis, $P$. oleracea, $G$. parviflora, entre outras. Algumas das espécies observadas nesse estudo, foram também encontradas em pomar de citros por Carmona (1995).

Nas parcelas onde foi aplicado dose reduzida de glyphosate (Figuras 23 a-b e $24 \mathrm{a}-\mathrm{b}$ ), o C. echinatus (L.), D. insularis (L.) Fedd. e C. rotundus foram encontrados no período da seca. Ressalta-se que em tratamento mecânico o $D$. insularis (L.) esteve presente no período da seca, denotando a influência do tratamento no aparecimento ou não de determinadas espécies.

Nas dicotiledôneas, obteve-se menor número de famílias e espécies do que no tratamento mecânico, mas as espécies presentes se repetem, com exceção para a Commmelina benghalensis (L.), que somente ocorreu no período chuvoso.

Mayor \& Dessaint (1988) obtiveram 27 espécies em área com controle químico, 21 para o integrado e mecânico. Porém estes autores não encontraram diferenças entre a riqueza das espécies.

Analisando-se as parcelas com leguminosas, as Figuras 25 a 28 apresentam os resultados das freqüências das espécies daninhas nesses tratamentos. Observou-se que houve uma redução no número de espécies presentes, ressaltando que durante o período seco em parcela com guandu, nenhuma gramínea foi encontrada. Em dicotiledôneas, não foi constatado familias e espécies diferentes daquelas presentes nos outros tratamentos. Observou-se no entanto em parcela de lab-lab uma maior incidência de espécies em relação às parcelas de guandu.

\subsubsection{Dinâmica populacional e freqüência das espécies na linha de plantio, para emergência em bandeja}

Nas Figuras 31a-b até 32 a-b estão os resultados obtidos na linha de plantio, onde utilizou-se os herbicidas diuron e glyphosate. Observa-se que nas 
Figura 31a Frequência (\%) das espécies daninhas na linha de plantio, glyphosate nos diferentes tratamentos no período chuvoso

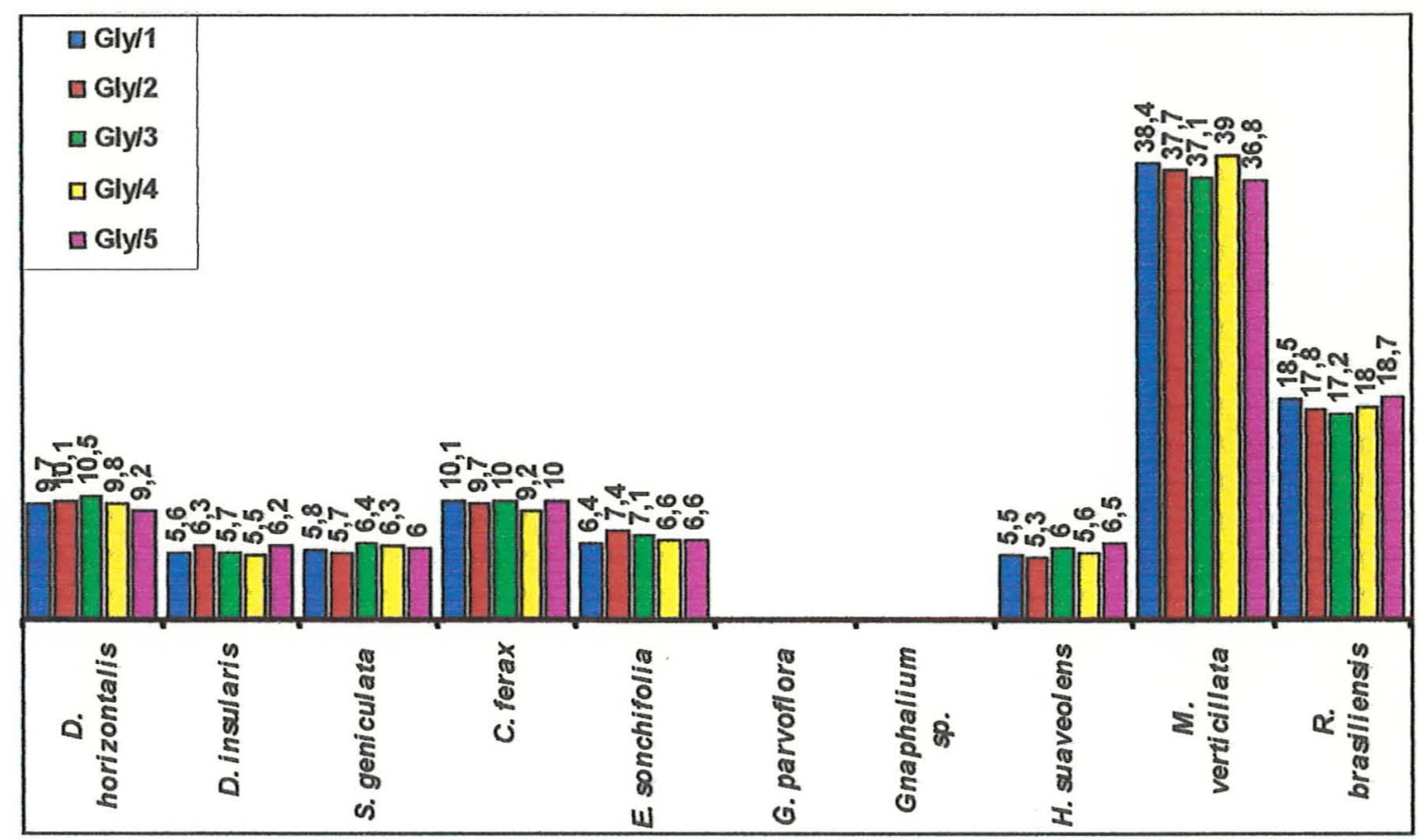

Figura 31b Frequência (\%) das espécies daninhas na linha de plantio - glyphosate nos diferentes tratamentos - período seco

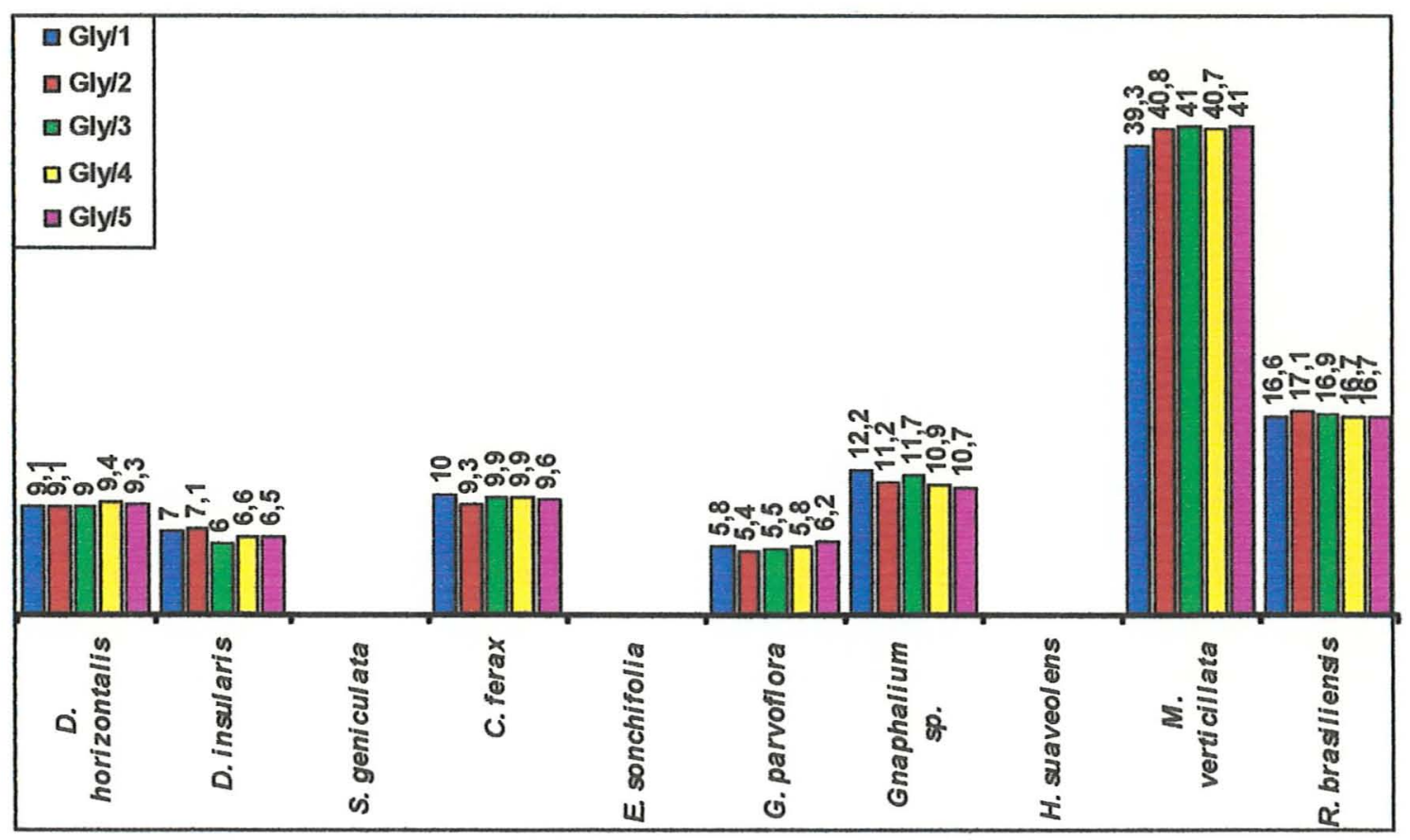


Figura 32a Frequência (\%) das espécies daninhas na linha de plantio - diuron nos diferentes tratamentos - período chuvoso

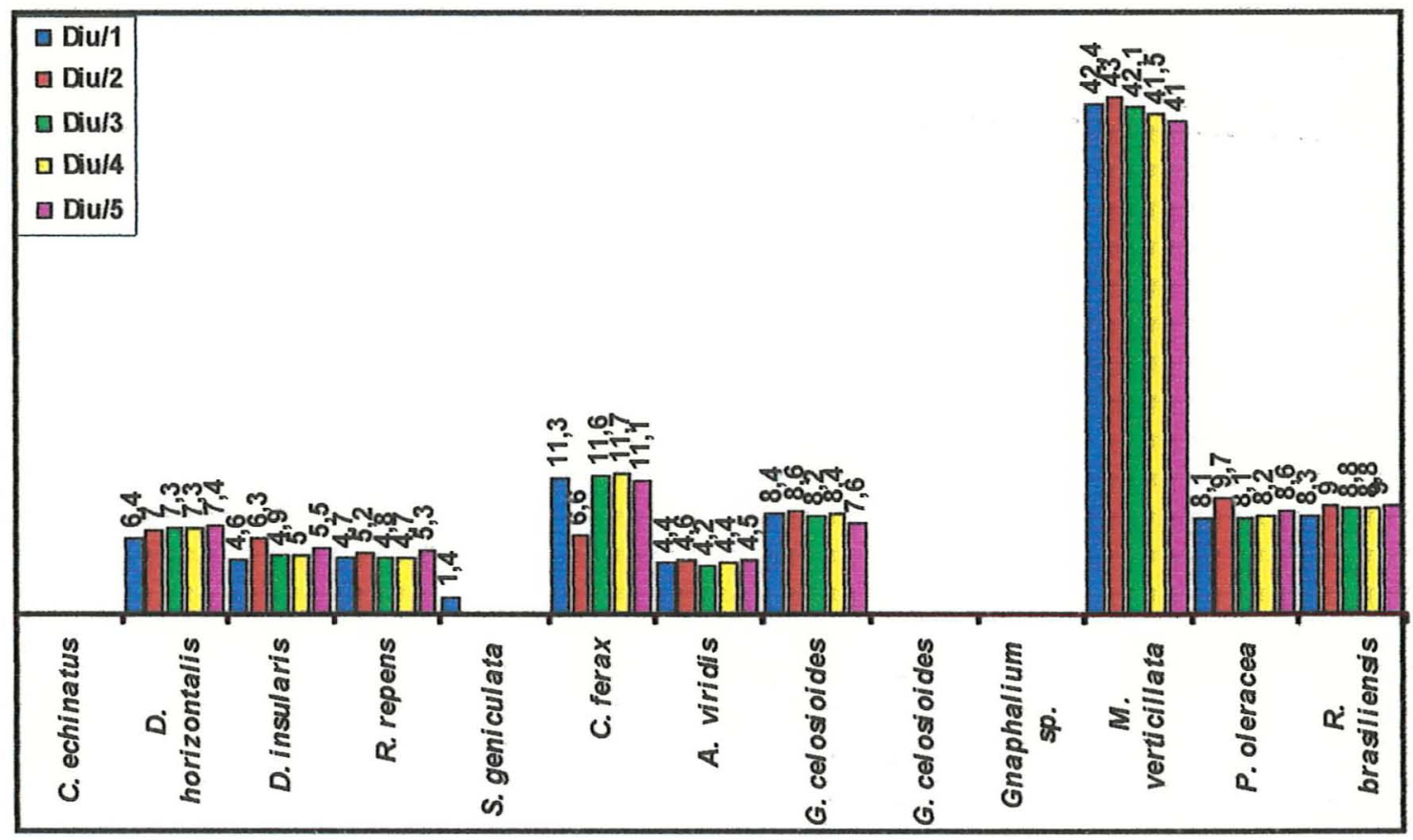

Figura 32b Frequência (\%) das espécies daninhas na linha de plantio - roçada/diuron período seco

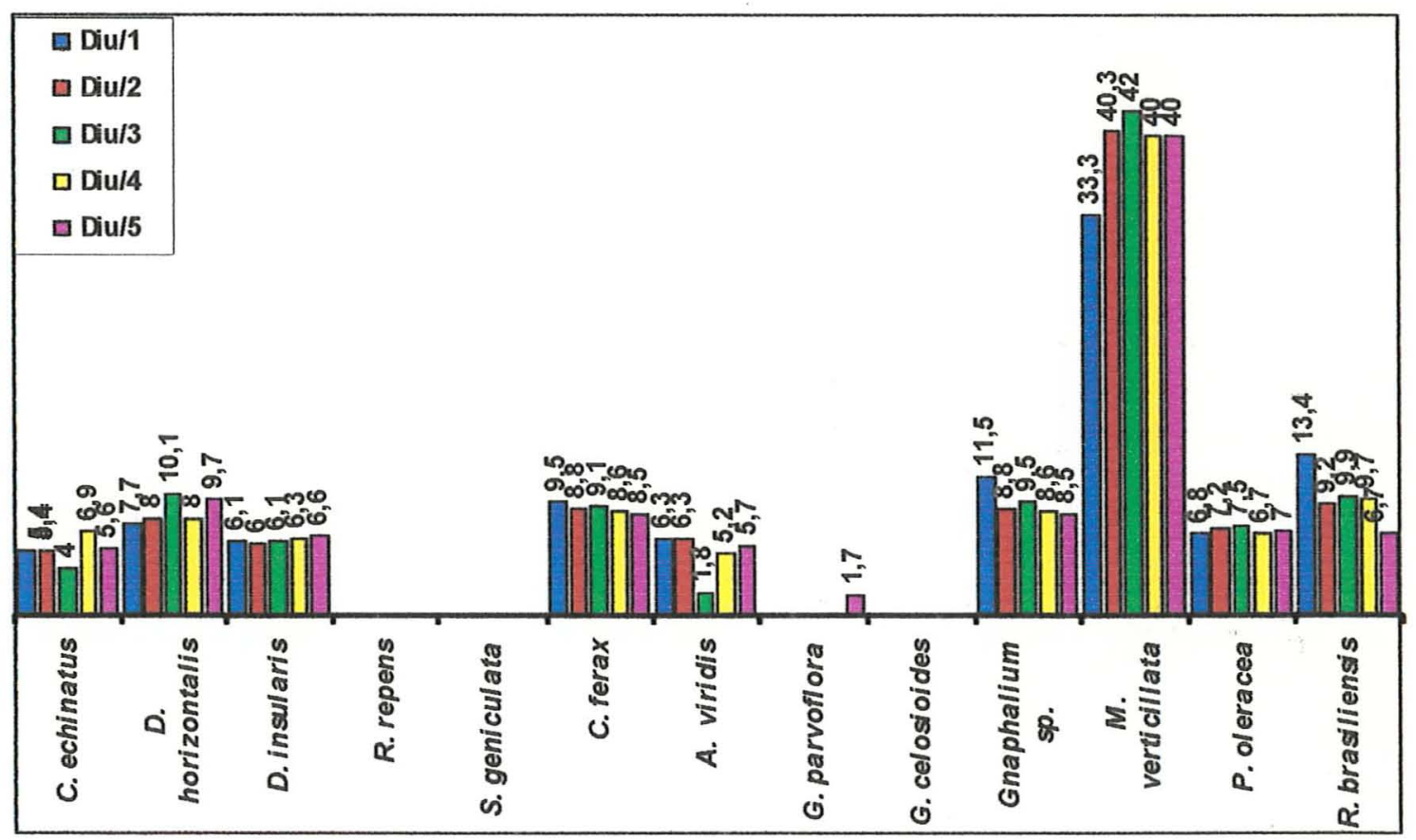


parcelas onde foi aplicado o diuron, foram encontradas sete familias e 13 espécies, enquanto que para o glyphosate encontrou-se oito espécies distribuídas em seis familias, sendo estas coincidentes para os dois herbicidas, com algumas exceções. Constata-se na parcela com diuron a presença de $S$. geniculata (lam.) Beauv., A viridis (L.), E. sonchifolia, G. celosioides Mart. $M$. verticillata (L.) e $H$. suaveolens (L.) Poit., somente durante o período da chuva; das espécies citadas apenas $G$. celosioides Mart pode ser encontrada durante todo o ano, as demais são predominantes em época chuvosa (Lorenzi, 1982); porém, C. echinatus (L.), G. parviflora Cav. e Gnaphalium sp., foram observadas na época da seca e, segundo o mesmo autor acima estas espécies vegetam melhor durante períodos de temperaturas mais amenas.

Nas parcelas com glyphosate somente o Rhynchelytrum repens e $G$. celosioides, foram encontrados no período da chuva, enquanto que Gnaphalium sp. foi observado somente no período seco.

Diferenças entre herbicidas glyphosate e diuron não foram encontradas por Adegas (1994) no controle de plantas daninhas, com exceção para o controle de $D$. horizontalis Willd, onde o glyphosate apresentou maior controle.

\subsubsection{Dinâmica populacional e freqüência do banco de sementes,} na entrelinha de plantio, no periodo chuvoso e seco

Nas Figuras 33 a-b até 37 a-b estão apresentados os valores das freqüências e dinâmica populacional do banco de sementes, obtidos na entrelinha de plantio, para todas as combinações de tratamentos aplicados, no período chuvoso e seco do ano.

$\mathrm{Na}$ combinação de tratamentos roçada com glyphosate e diuron (Figuras $33 \mathrm{a}-\mathrm{b}$ ) foram encontradas 10 espécies, sendo três monocotiledôneas e sete dicotiledôneas, no período chuvoso e 12 espécies (três mono e nove dicotiledôneas). Ressalta-se a presença ou ausência de determinadas espécies de plantas daninhas nos períodos avaliados, tendo-se $D$. insularis (L.) Fedd, $E$. 
Figura 33a Frequência (\%) do banco de sementes na entrelinha de plantio, roçada no período chuvoso do ano

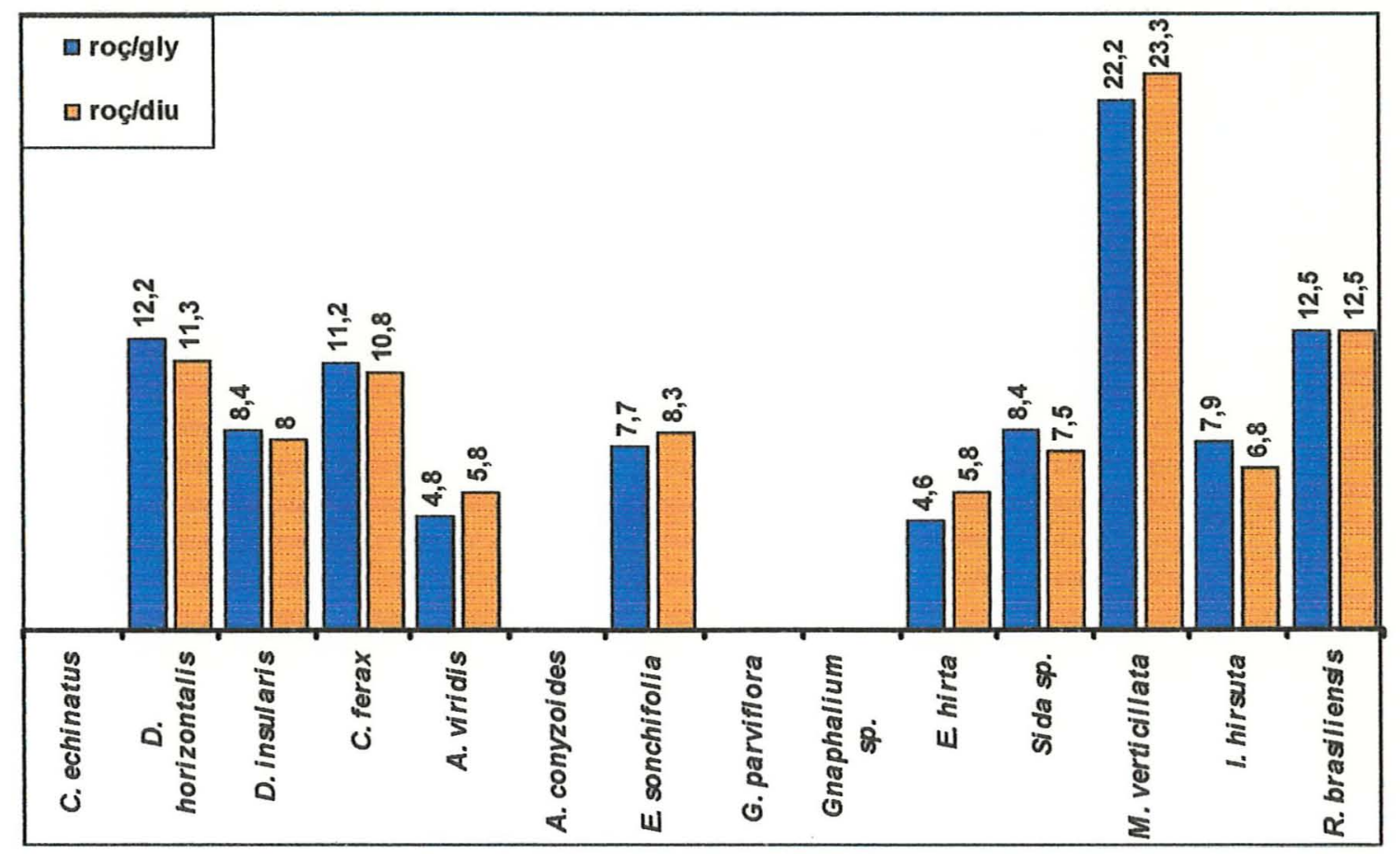

Figura 33b Frequência (\%) do banco de sementes na entrelinha de plantio, roçada no período seco do ano

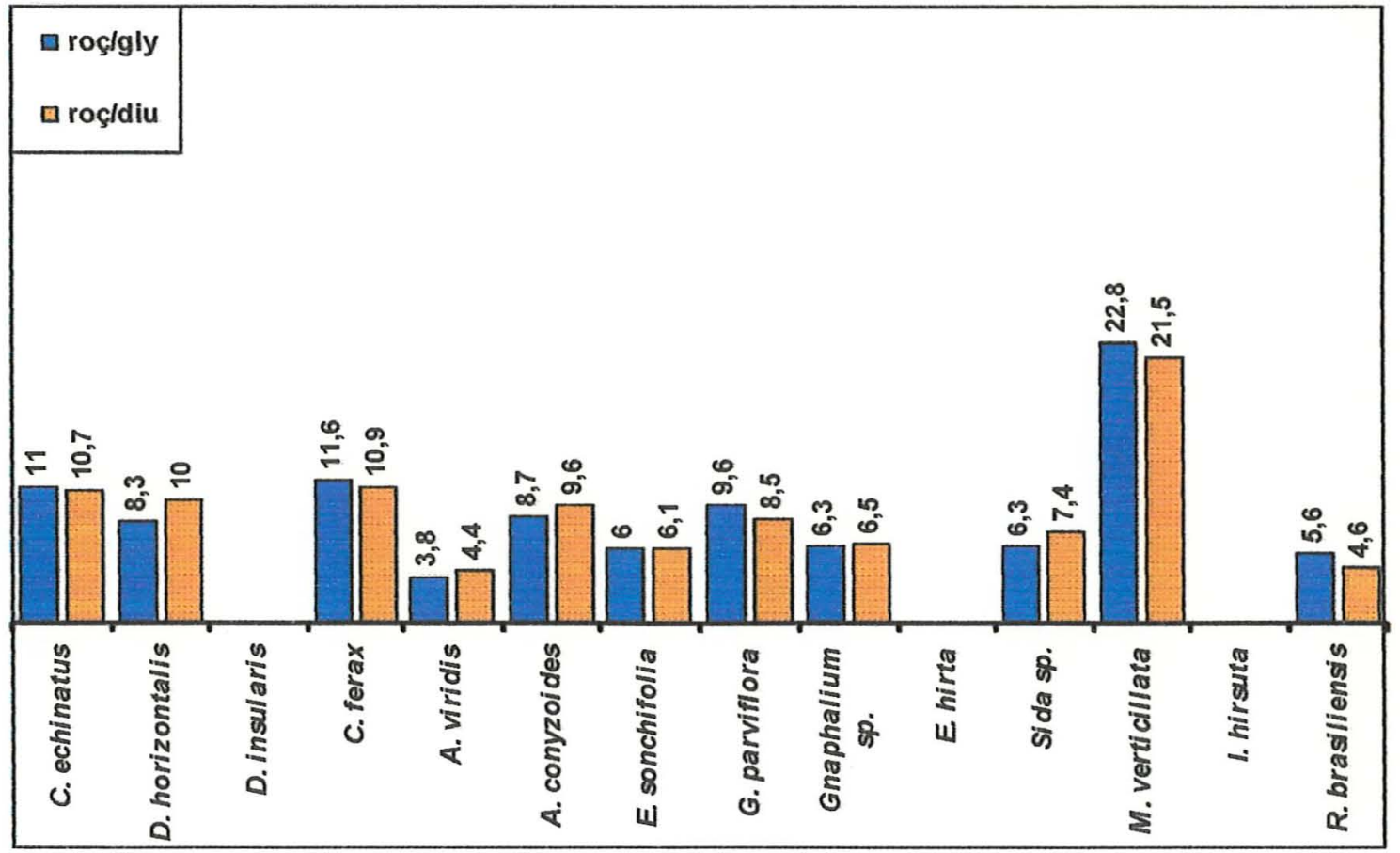


Figura 34a Frequência (\%) do banco de sementes na entrelinha de plantio, glyphosate no período chuvoso do ano

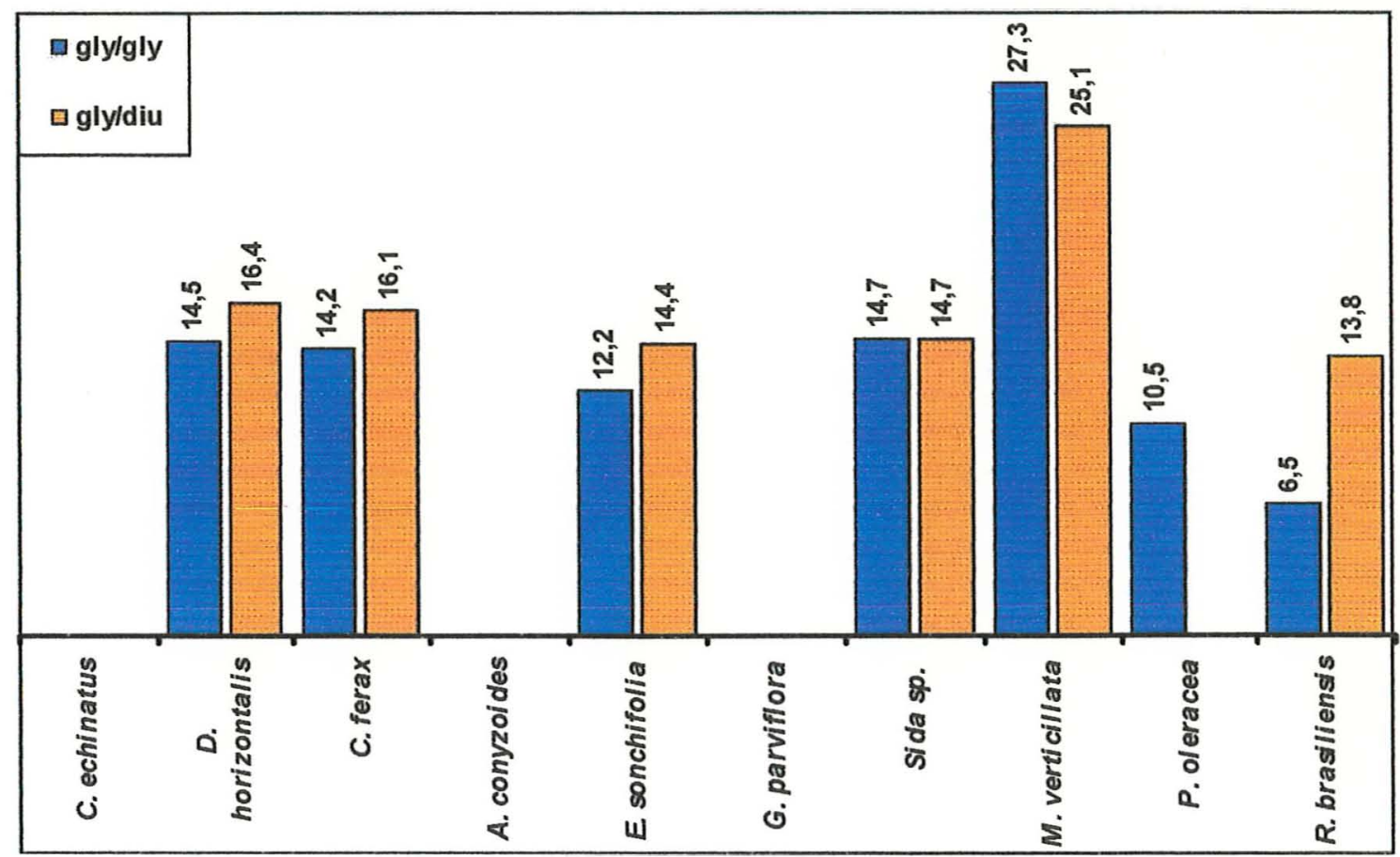

Figura 34b Frequência (\%) do banco de sementes na entrelinha de plantio, glyphosate no período seco do ano

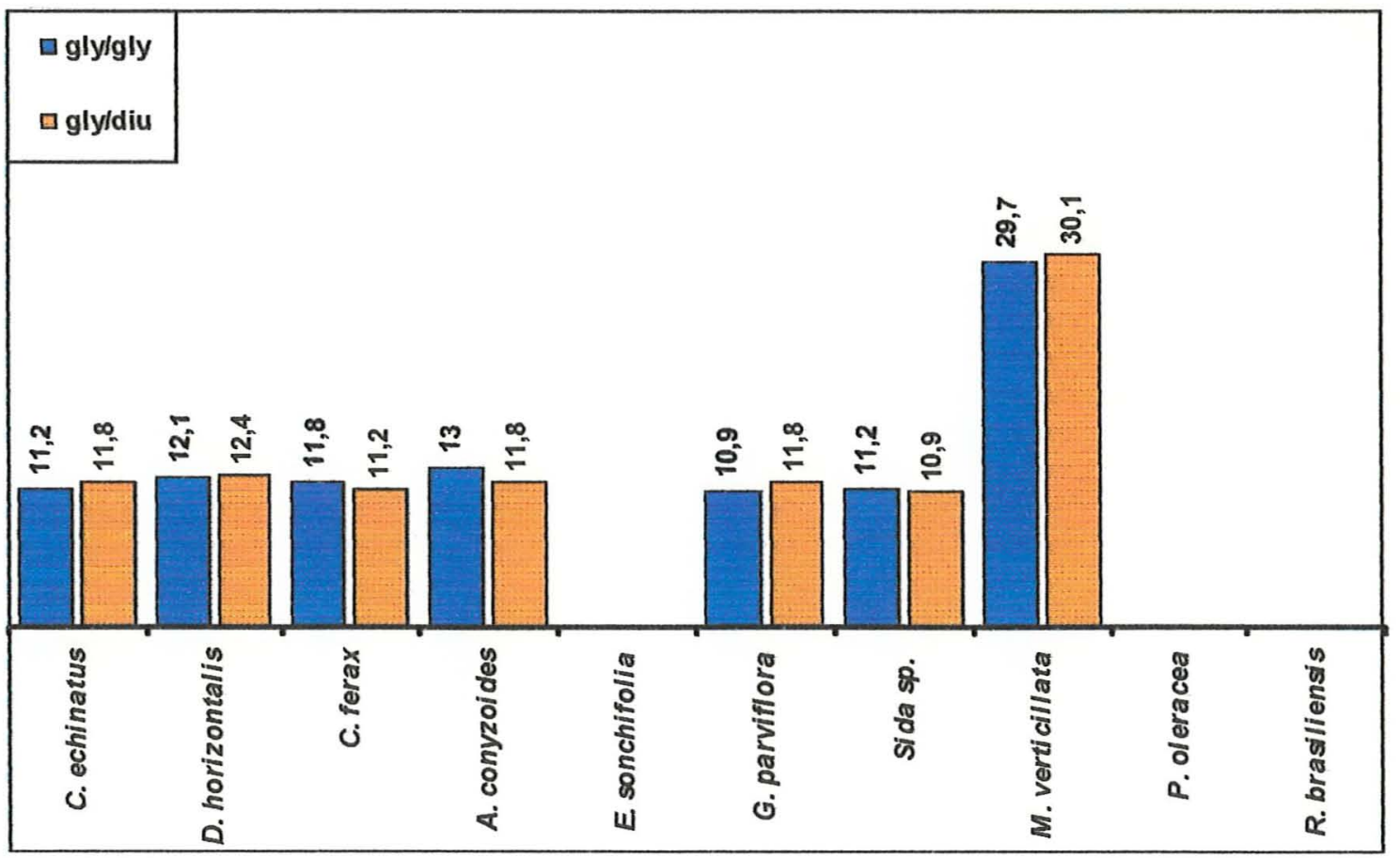


Figura 35a Frequência (\%) do banco de sementes na entrelinha de plantio, guandu no período chuvoso do ano

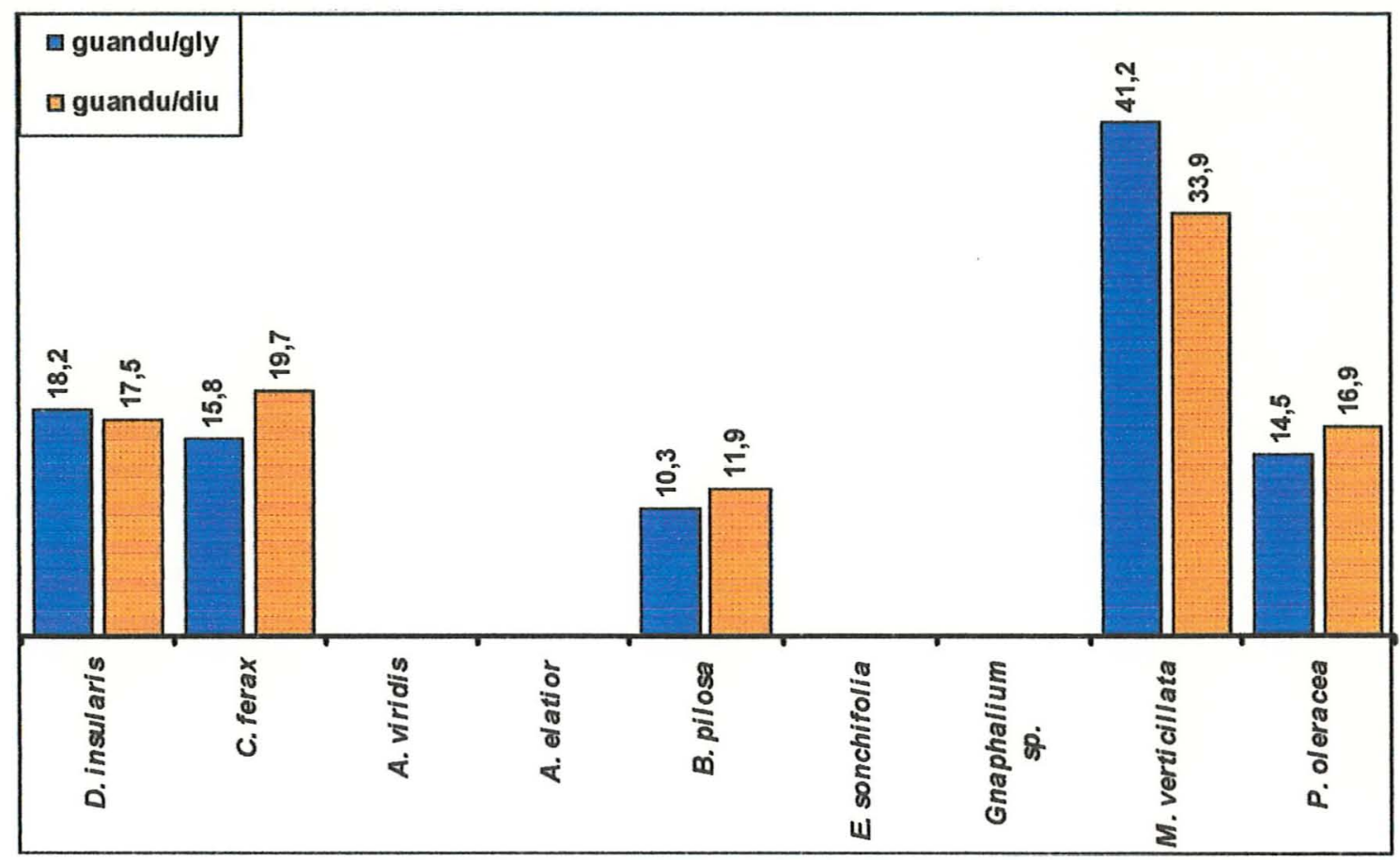

Figura 35b Frequência (\%) do banco de sementes na entrelinha de plantio, guandu no período seco do ano

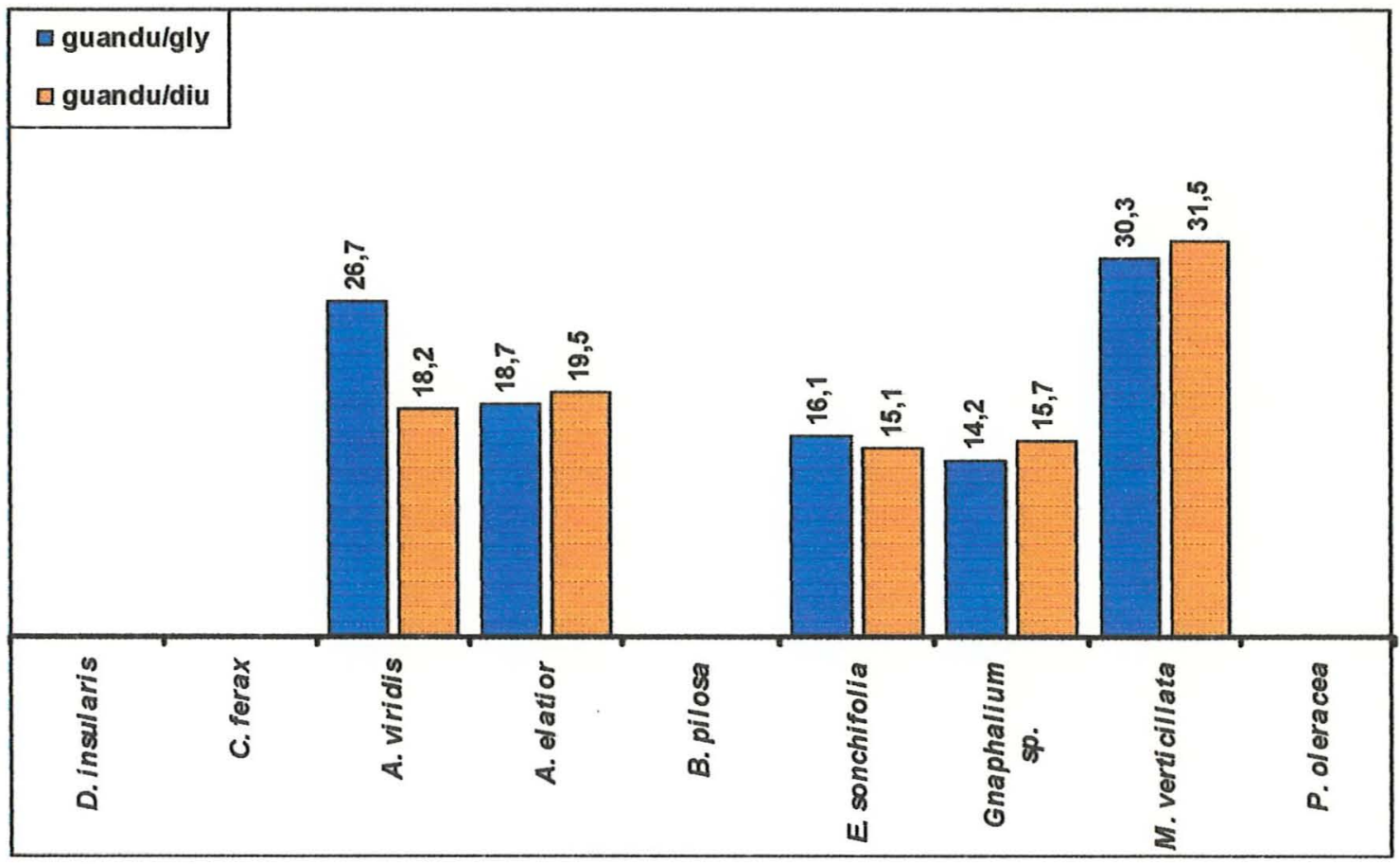


Figura 36a Frequência (\%) do banco de sementes na entrelinha de plantio, lab-lab no período chuvoso do ano

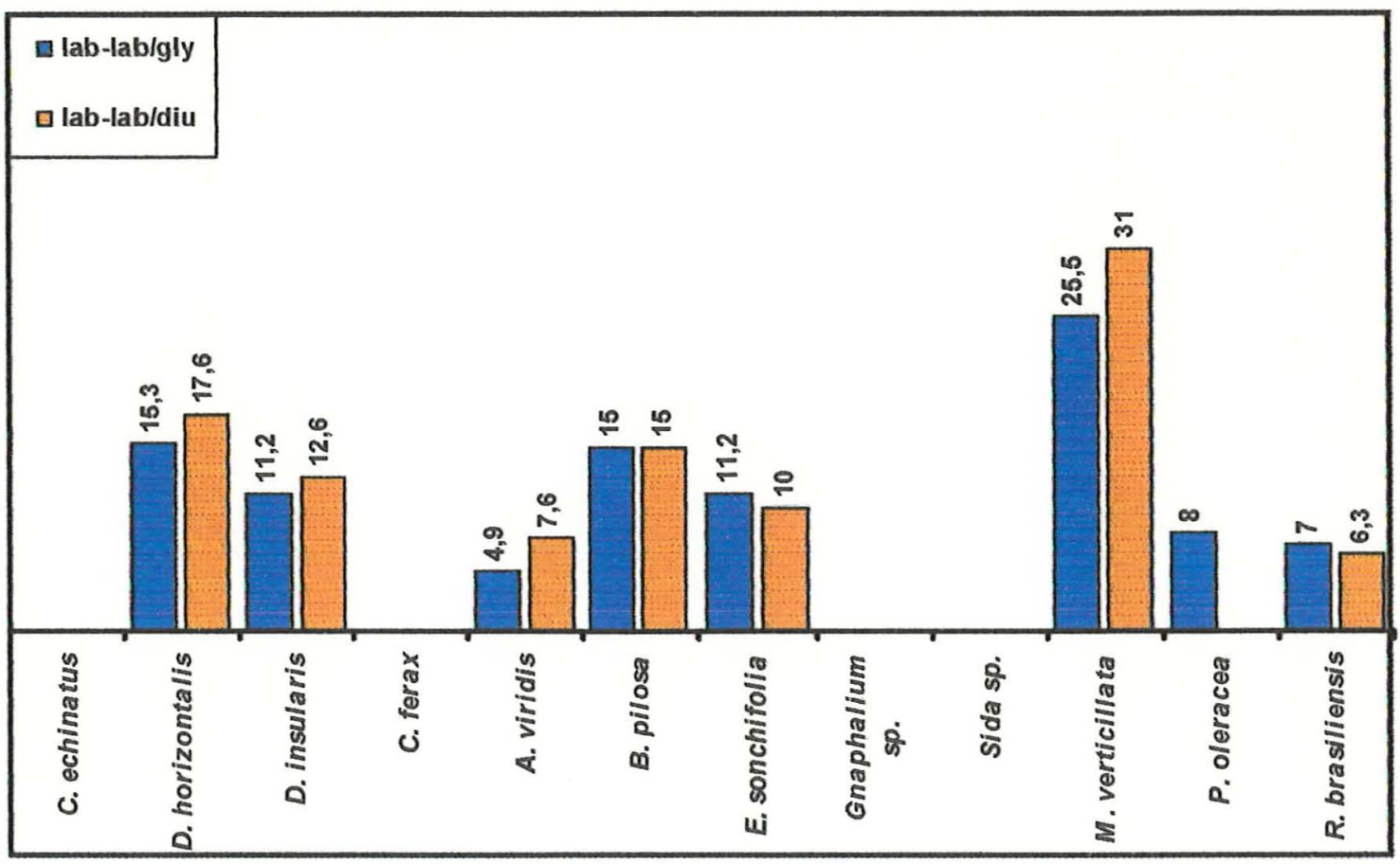

Figura 36b Frequência (\%) do banco de sementes na entrelinha de plantio, lab-lab no período seco do ano

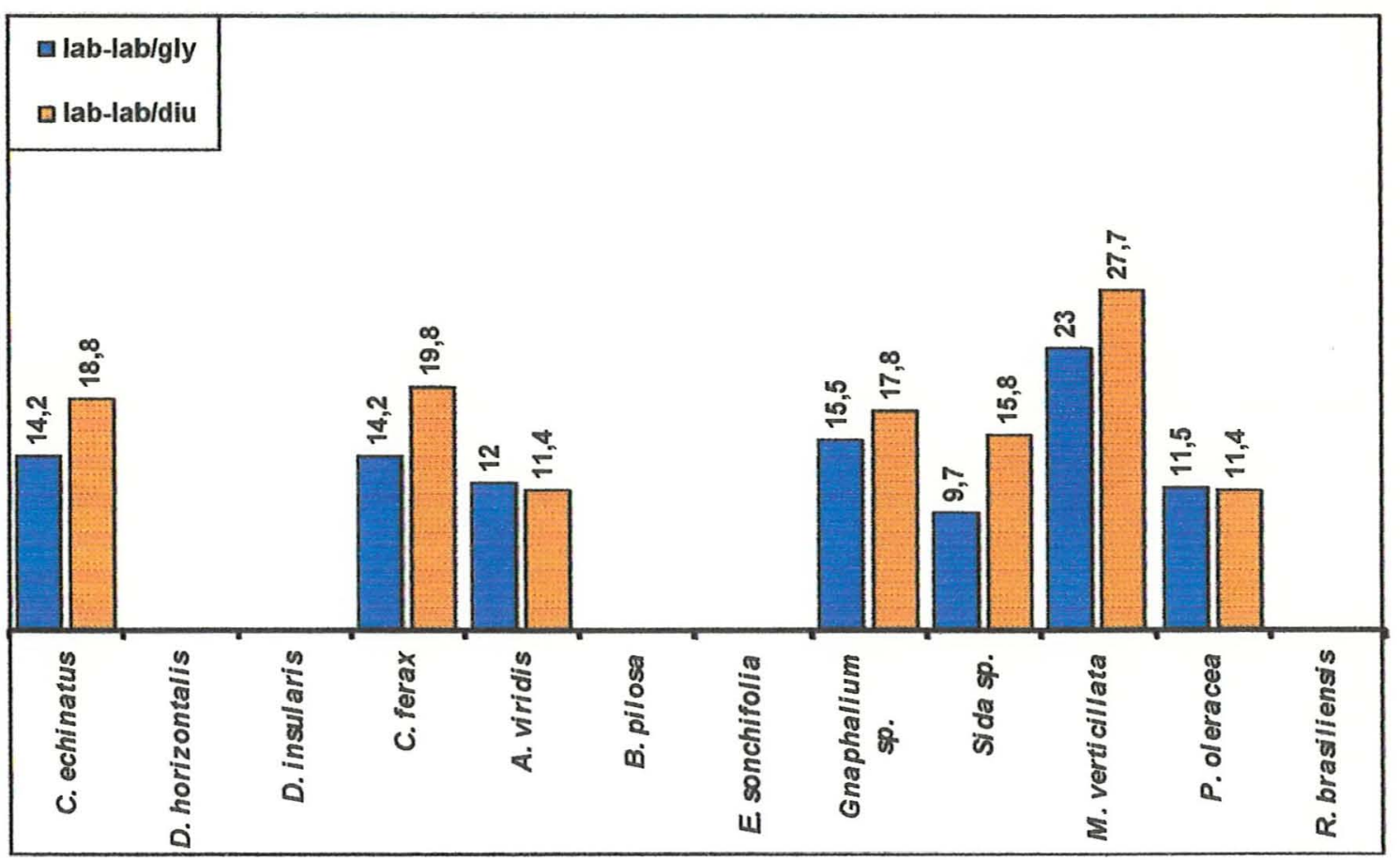


Figura 37a Frequência (\%) do banco de sementes na entrelinha de plantio, gradagem no período chuvoso do ano

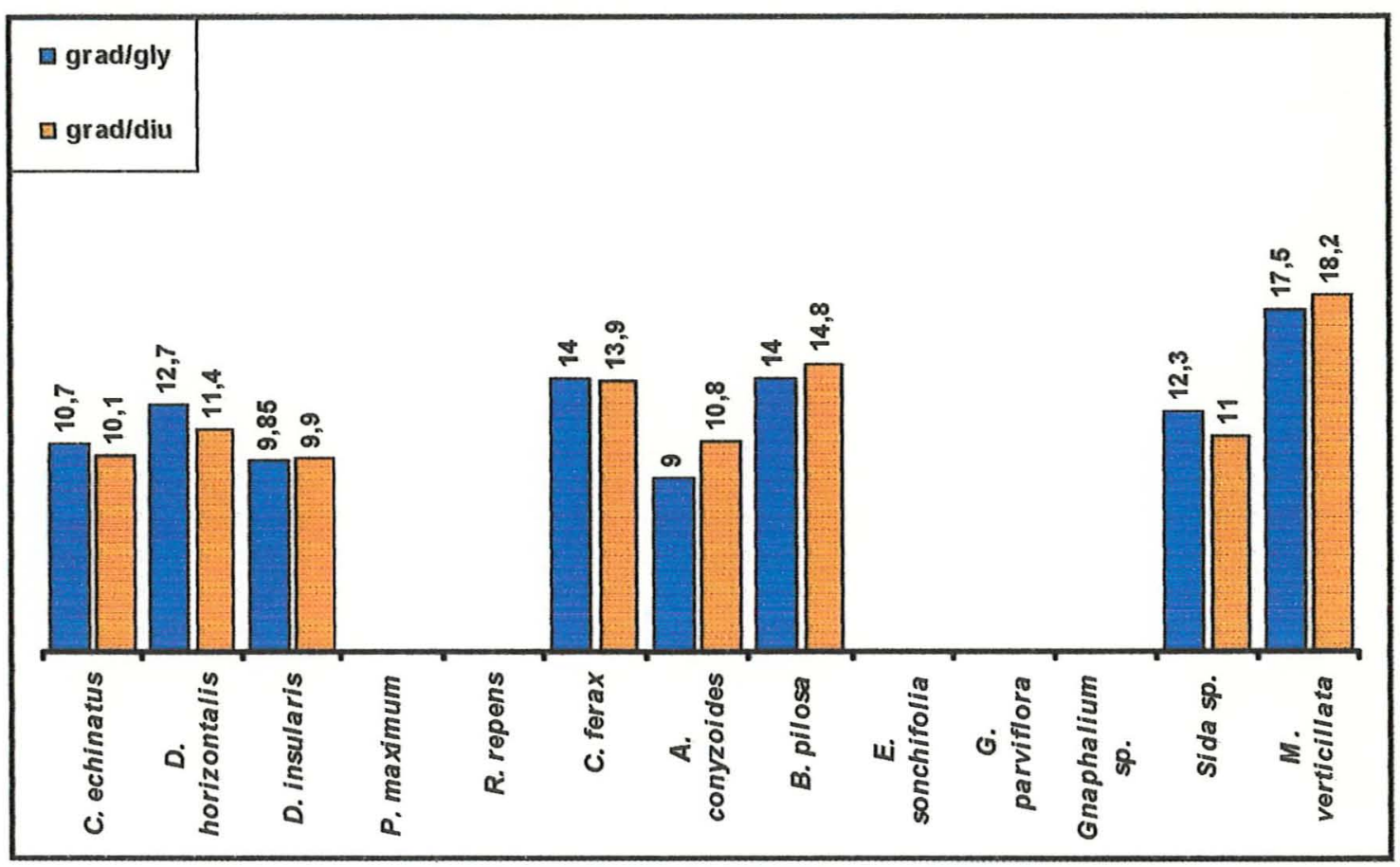

Figura 37b Frequência (\%) do banco de sementes na entrelinha de plantio, gradagem no período seco do ano

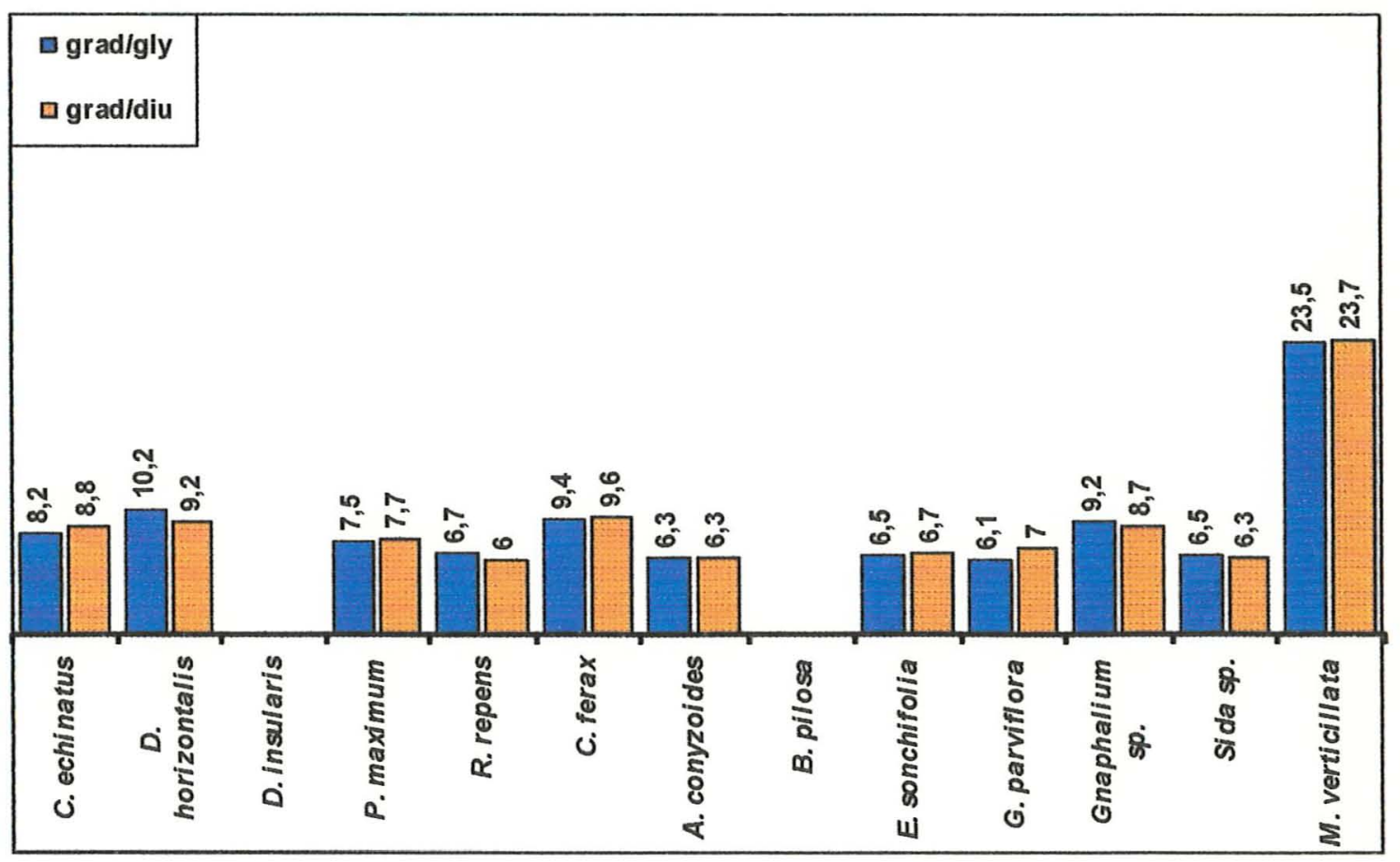


hirta (L.) Mill e I. hirsuta (L.) no período chuvoso; na época seca observou-se C. echinatus (L.), A. conyzoides (L.), G. parviflora Cav. e Gnaphalium sp.

Em relação às freqüências das sementes das espécies daninhas, no período seco apresentou menores valores para este fator, do que o chuvoso, destacando-se os valores da freqüência de $R$. brasiliensis Gomez, que obteve indices abaixo da metade do que foi alcançado no período chuvoso.

Analisando-se outra combinação de tratamentos mecânicos (Figuras 37 a-b) foram encontrados oito espécies, sendo quatro mono e cinco dicotiledôneas para o período das chuvas e 11 espécies no seco (5 mono e 6 dicotiledôneas). A presença de $P$. maximum (Jacq.) e R. repens (Willd.) C.E. Hubb. na época seca sugere que há influência do tipo de tratamento e época na presença da espécie daninha. Para as freqüências, foi encontrada a mesma relação da combinação anterior.

Nas combinações de dose reduzida de glyphosate (Figuras 34 a-b) encontrou-se sete espécies tanto para a época chuvosa como na seca. Ressalta-se a presença de $P$. oleracea (L.) apenas quando combinou-se dose reduzida de glyphosate na entrelinha com dose recomendada na linha; este resultado pode estar relacionado com a grande afinidade a água que a espécie apresenta.

As combinações de guandu (Figuras $35 a-b$ ) apresentaram o menor número de espécies de plantas daninhas, cinco para a época chuvosa e seca, em relação as outras combinações avaliadas. Observa-se também que durante o período da seca não foi encontrada nenhuma espécie monocotiledônea, fato que não coincide com as observações de Alcântara \& Carvalho (1982).

Com relação as combinações com lab-lab (Figura 36 a-b) observa-se que a $P$. oleracea (L.) apresenta comportamento semelhante a combinação dose reduzida de glyphosate e dose recomendada do mesmo herbicida. Este resultado evidencia a influencia da época sobre a incidência de determinadas espécies daninhas. De um modo geral, as freqüências encontradas no período chuvoso foram maiores que na época seca. 


\subsubsection{Dinâmica populacional e freqüência do banco de sementes,} na linha de plantio, no período chuvoso e seco

Nas Figuras $38 a-b$ até $39 a-b$ estão apresentados os resultados referentes as frequiências e dinâmica populacional obtidos no banco de sementes, para as combinações dos herbicidas glyphosate e diuron.

Observa-se que as espécies de sementes presentes na linha de plantio são as mesmas encontradas na entrelinha; constata-se também que as combinações de tratamentos e a época de avaliação, também influenciam a presença de determinadas espécies.

Em relação ao fato citado acima, os exemplos também são os mesmos dos encontrados na entrelinha de plantio; fica então, evidenciado que há uma influência dos tratamentos da entrelinha no banco de sementes da linha. Isto sugere que, a depender do método de controle utilizado, plantas daninhas escape, podem produzir sementes e estas retornarem ao próprio banco de sementes ou estas serem disseminadas para áreas próximas.

Verifica-se também que todas as espécies que foram encontradas no banco de sementes apresentam reprodução por semente, sendo estas de tamanho pequeno e a maioria dotadas de apêndices para auxiliar na dispersão, como a E. sonchifolia, D.C., G. parviflora Cav., C. echinatus L., D. insularis (L.) Mea ex Ekman e R. repens (Willd.) C.E. Hubb. 
Figura 38a Frequência (\%) das espécies daninhas na linha de plantio, glyphosate nos diferentes tratamentos no período chuvoso do ano

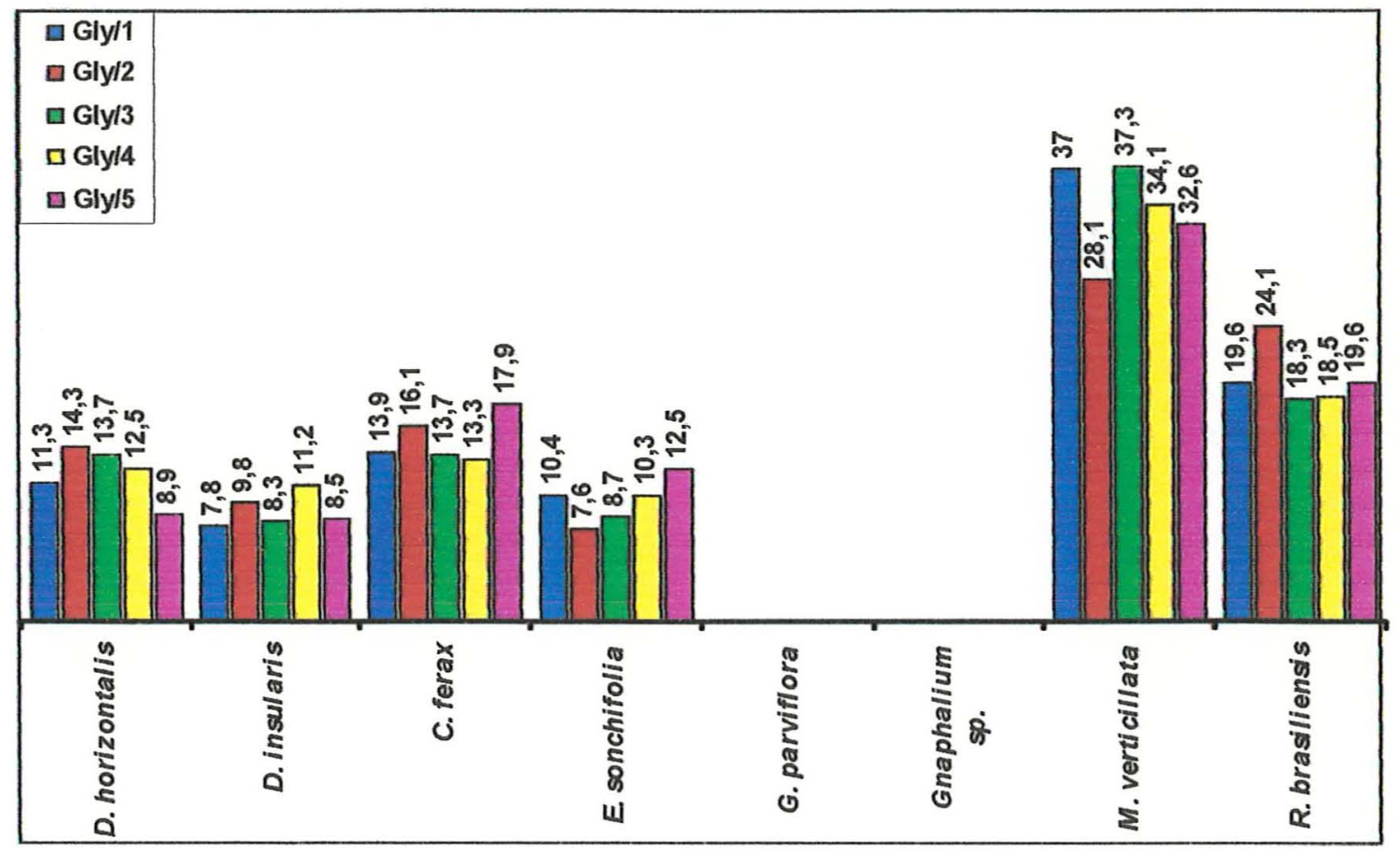

Figura 38b Frequência (\%) do banco de sementes na linha de plantio, glyphosate nos diferentes tratamentos no período seco do ano

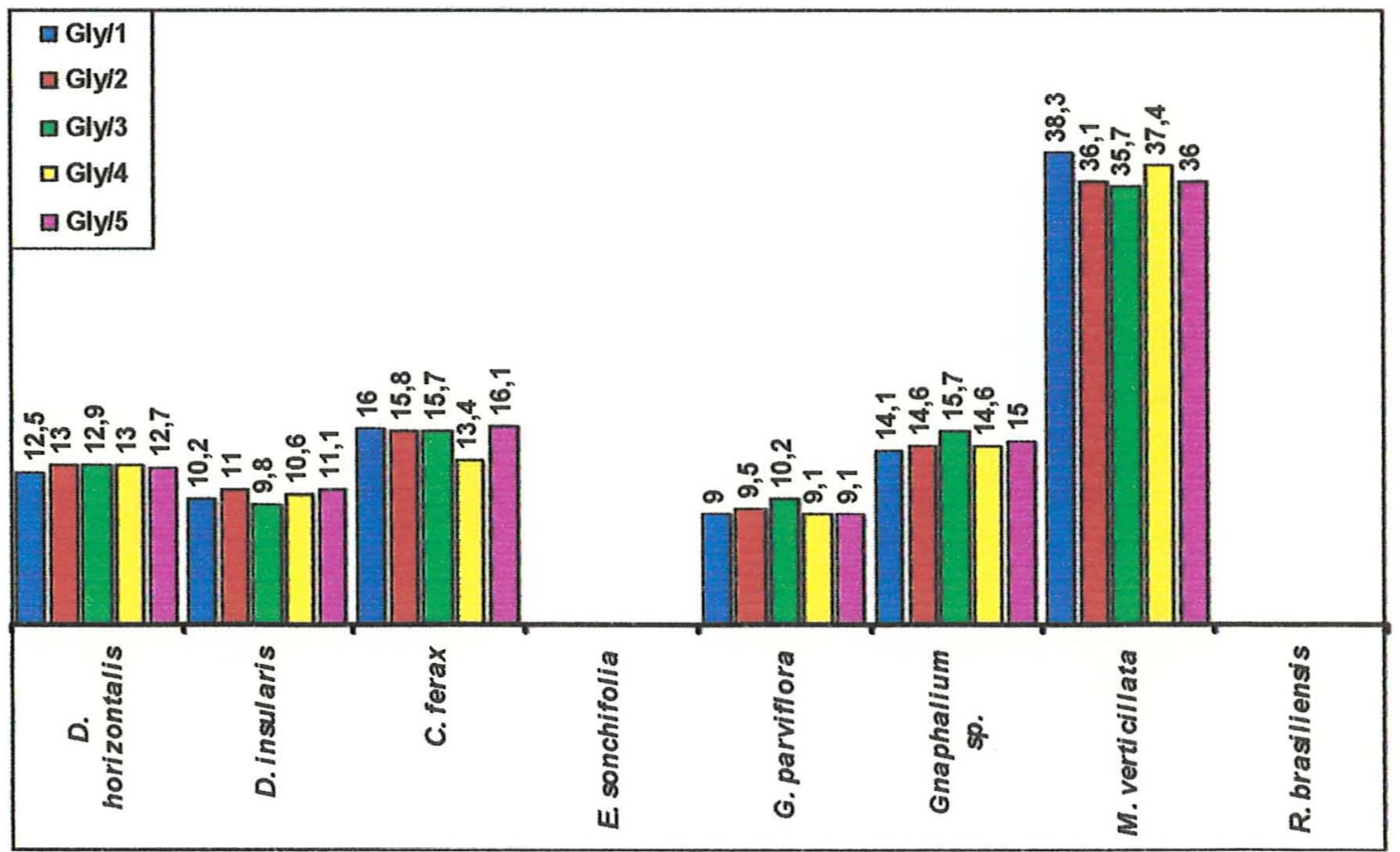


Figura 39a Frequência (\%) do banco de sementes na linha de plantio, diuron nos diferentes tratamentos, no período chuvoso do ano

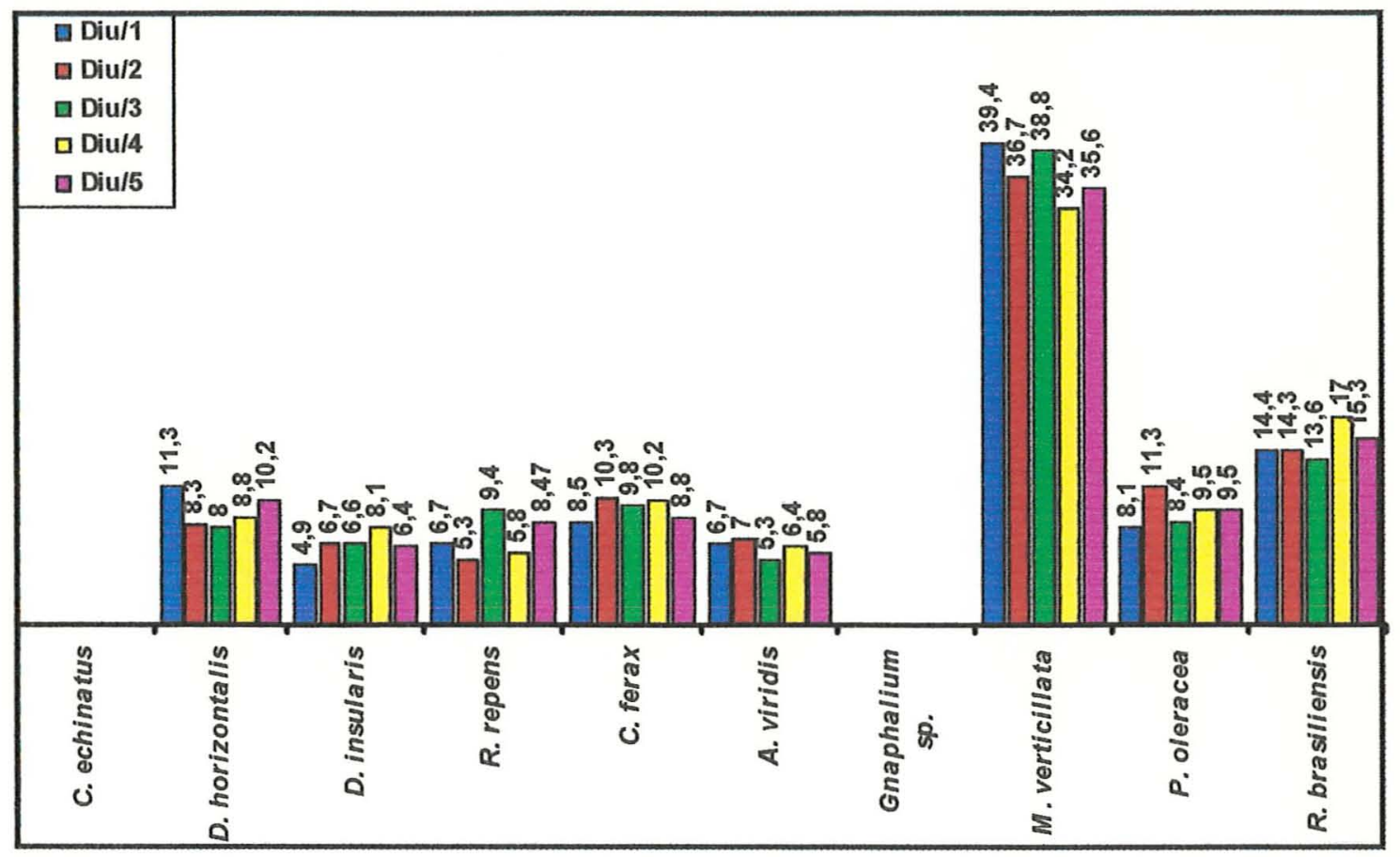

Figura 39b Frequência (\%) do banco de sementes na linha de plantio, diuron nos diferentes tratamentos, no período seco do ano

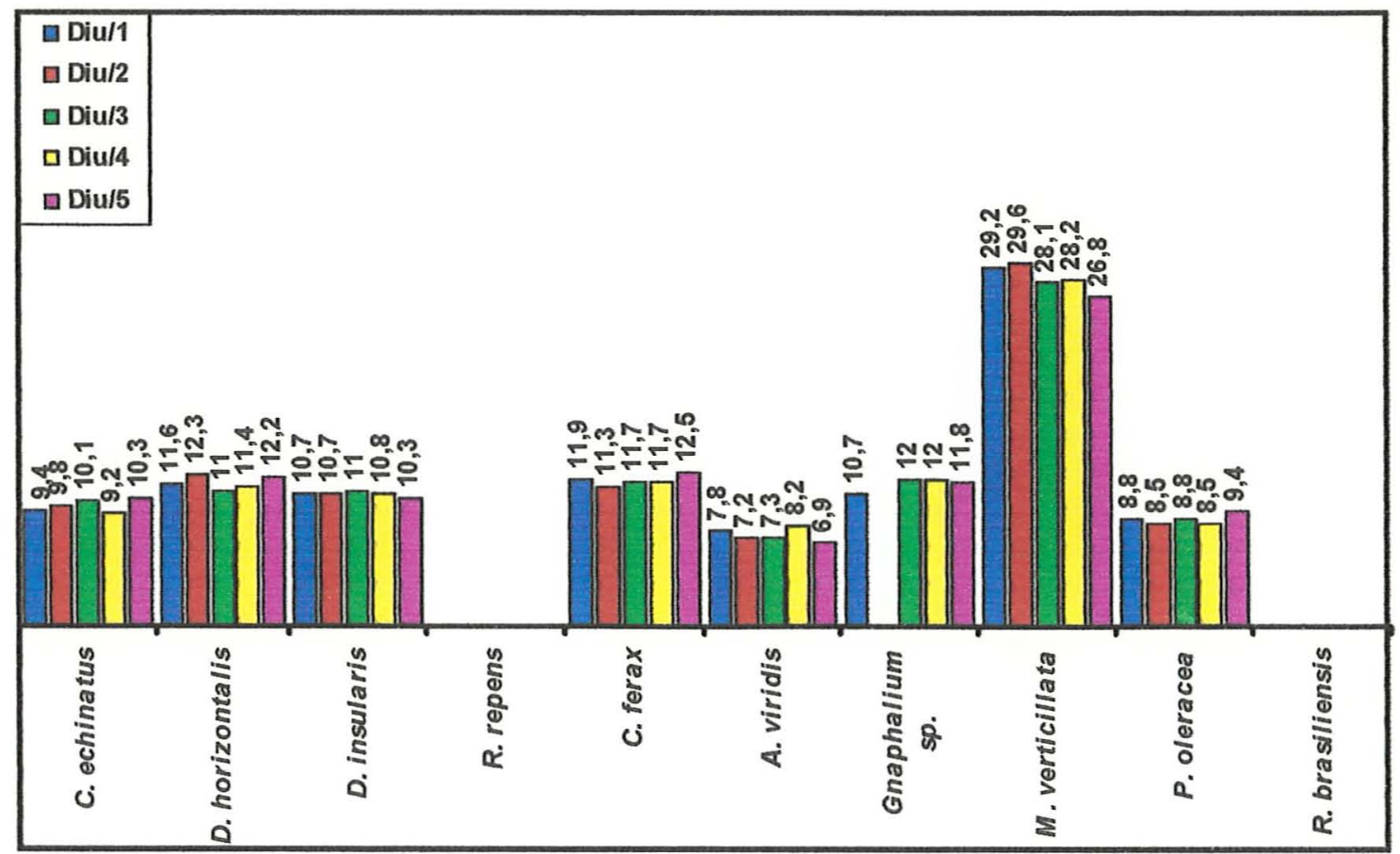




\section{CONCLUSÕES}

1. O plantio de leguminosas (guandu ou lab-lab) na entrelinha de citros em formação reduz significativamente a população de sementes de plantas daninhas no solo, bem como a porcentagem de sementes não dormentes, quando comparadas com o manejo mecânico desta área (roçada ou gradagem).

2. Dentre os adubos verdes guandu e lab-lab, o primeiro altera a dinâmica do banco de sementes de forma mais significativa que 0 lab-lab, pois o número de plântulas emergidas e de sementes é menor na amostragem de solo provenientes deste tratamento.

3. Existe uma interação significativa entre os tratamentos usados nesta pesquisa e a distribuição do banco de sementes no perfil do solo, embora em todos os tratamentos existe maior concentração de sementes dos 0$10 \mathrm{~cm}$ que dos $10-20 \mathrm{~cm}$ de profundidade. No entanto, o uso de gradagem proporciona uma distribuição menos diferenciada do banco de sementes nestas duas profundidades.

4. A aplicação de herbicidas como forma de manejo de plantas daninhas em citros influi na distribuição do banco de sementes no perfil do solo. $O$ herbicida glyphosate permite a formação de maior população de sementes de plantas daninhas quando comparado com o diuron na linha do citros ou com os demais tratamentos usados na entrelinha. 
5. A análise dos parâmetros quantitativos e qualitativos do banco de sementes não mostra diferenças quando comparados os periodos chuvoso e seco do ano, em qualquer dos tratamentos utilizados.

6. Os tratamentos aplicados na linha de plantio influencia diretamente a população do banco de sementes tanto da linha como da entrelinha, o mesmo acontecendo com os tratamentos aplicados na entrelinha. Esta influência é função da dispersibilidade das sementes das plantas daninhas durante a 'chuva de sementes'. 


\section{REFERÊNCIAS BIBLIOGRÁFICAS}

ADEGAS, F.S. Efeitos de diferentes sistemas de preparo antecipado do solo e herbicidas de manejo na infestação de plantas daninhas na cultura do algodoeiro (Gossypium hirsutum L. var. latifolium Hutch.). Piracicaba, 1994, 109p. Dissertação (M.S.) Escola Superior de Agricultura 'Luiz de Queiroz'.

AGENBAG, G.A.; DE VILLIERS, O.T. The effect of nitrogen fertilizers on the germination and seedling emergence of wild oat (A. fatua, L.) seed in different soil types. Weed Research, v.29, p.239-245, 1989.

ALCÂNTARA, E.N.; CARVALHO, D.A. de. Controle de plantas daninhas. Informe Agropecuário, v.8, p.30-33, 1982.

BAKER, H.G. Some aspects of the natural hystory of seed banks. In: LECK, M.A.; PARKER, V.T.; SIMPSON, R.L. (Eds.). Ecology of soil seed banks. London: Academic Press, 1989. Cap.1, p.5-19.

BALL, D.A. Weed seedbank response to tillage, herbicides, and crop rotation sequence. Weed Science, v.40, p.654-659, 1992

BALL, D.A.; MILLER, D.S. comparasion of techniques for estimation of arable soil seedbanks and their relationships to weed flora. Weed Research, v.19, p.365-373, 1989.

BALL, D.A.; MILLER, S.D. Weed seed population response to tillage, and herbicide use in three irrigated cropping sequence. Weed Science, v.38, p.511-517, 1990. 
BARBERI, P.; COZANI, A.; MACCHIA, M.; BONARI, E. Size and composition of the weed seedbank under different management systems for continuous maize cropping. Weed Research, v.38, p.319-334, 1998.

BARRALIS, G.; CHADOEUF, R. Potential de semencier du terres arables. Weed Research, v.27, p.417-424, 1987.

BARRALIS, G.; CHADOEUF, R.; LOCHAMP, J.P. Longevité des semences des mauvaises herbes annuelles dans un sol cultivé. Weed Research, v.28, p. $407-417,1988$.

BARRALIS, G; CHADOEUF, R.; GOUET, J.P. Essai de determination de la taile de l'echantillon pour l'etude du potentiel semencier d'un sol. Weed Research, v.26, p.292-297, 1986.

BASKIN, J.M.; BASKIN,C.C. Physiology of dormency and germination in relation to seed bank ecology. In: LECK, M.A.; PARKER, V.T. ; SIMPSON, R.L. (Ed.). Ecology of soil seed banks. London: Academic Press, 1989. Cap.4, p.53-66.

BENOIT, D.L.; KENEL, N.C.; CAVERS, P.B. Factors influencing the precision of soil seed bank estimates. Canadian Journal of Botany, v.67, p.2833-2840, 1989.

BIGWOOD, D.W.; INOUYE, D.W. Spatial pattern analysis of seed banks: on improved method and optimized sampling. Ecology, v.69, p.497-507, 1988.

BLANCO, H.G.; BLANCO, F.M.G. Efeito do manejo do solo emergència de plantas daninhas anuais. Pesquisa Agropecuária Brasileira, v.26, p.215$220,1991$. 
BLANCO, H.G.; OLIVEIRA, D.A. Estudos dos efeitos da época de controle do mato sobre a produção de citrus e a composição da flora daninha. Arquivos do Instituto Biológico, v.45, p.25-36, 1978.

BRENCHLEY, W.E. Burried weed seeds. Journal Agriculture of Science, v. 9 , p.1-31, 1918.

BUHLER, D.D. Influence of tillage systems on weed populations dynamics and management in corn and soybean in the central USA. Crop Science, v.35, p.1247-1258, 1995.

BUHLER, D.D.; HARTZLER, R.G.; FORCELLA, F. Implications of weed seedbank dynamics to weed management. Weed Science, v.45, p.329-336, 1997.

BULHER, D.D.; MAXWELL, B.D. Seed separation and enumeration from soil using $\mathrm{K}_{2} \mathrm{CO}_{3}$-centrifugation and image analyses. Weed Science, v.41, p.298-303, 1993.

BULISANI, E.A.; BRAGA, N.R.; ROSTON, A.J. Utilização de leguminosas como cobertura do solo em sistemas de adubação verde ou rotação de culturas. In: FANCELLI, A.L. (Coord.). Plantio Direto. Piracicaba: FEALQ/ESALQ/USP, 1987. p.63-70.

CAETANO, A.A. Tratos culturais. In: Rodrigues, O.; VIÉGAS, F. Citricultura Brasileira. Campinas: Fundaçăo Cargill, 1980. V.2, p.442-466.

CAIRNS, A.L.P.; DE VILLIERS, O.T. Breaking dormancy of Avena fatua L. seed by treatment with ammonia. Weed Research, v.26, p.191-197, 1986.

CARDINA, J.; NORQUAY,H.M. Seed production and seedbank dynamics in subthreshold velvetleaf (Abutilon theophrasti) populations. Weed Science, v.45, p.85-90, 1997. 
CARDINA, J.; REGNIER, E.; HARRISON, K. Long-term tillage effects on seed banks in three ohio soils. Weed Science, v.39, p.186-194, 1991.

CARDINA, J.; SPARROW, D.A comparison of methods to predict weed seedling populations from the soil seedbank. Weed Science, v.44, p.46-51, 1996.

CARMONA, R. Banco de sementes e estabelecimento de plantas daninhas em agroecossistemas. Planta Daninha, v.13, p.3-9,1995.

CARMONA, R. Problemática e manejo de banco de sementes de invasoras em solos agrícolas. Planta Daninha, v.10, p.5-16, 1992.

CARMONA, R.; MURDOCH, A.J. Interação entre temperatura e compostos superadores de dormência na germinaçăo de sementes de plantas daninhas. Revista Brasileira de Sementes, v.18, p.88-97, 1996.

CARVALHO, J.E.B. de; CALDAS, R.C.; CARDOSO, S.S. et al. Influència das épocas de controle da plantas daninhas na produção de laranja 'Pera'. Planta Daninha, v.11, p.49-54, 1993.

CARVALHO, J.E.B. de; REZENDE, G. de O.; CAETANO, R.S.X. et al. Controle de plantas daninhas em pomar de laranjeira 'Pera' com herbicidas à base de glyphosate e 2,4-D. Revista Brasileira de Fruticultura, v.12, p.17-23, 1990.

CARVALHO, M.M.; NAKAGAWA, J. Sementes: ciência, tecnologia, produção. Campinas: Fundação Cargill, 1983. 429p.

CARVALHO, P.C.F.; FAVORETTO, V. Impacto das reservas de sementes no solo sobre a dinâmica populacional das pastagens. Informativo Abrates, v.5, p.87-108, 1995.

CAVERS, P.B. Seed demography. Canadian Journal of Botany, v.61, p.3578$3590,1983$. 
CAVERS, P.B.; BENOIT, D.L. Seed banks in arable land. In: LECK, M.A.; PARKER, V.T. \& SIMPSON, R.L. (Ed). Ecology of soil seed banks. London: Academic Press, 1989. p. 309-328.

CHADOEUF-HANNEL, R. La dormance chez les semences des mauvaises herbs. Agronomie, v.5, p.761-772, 1985.

CHAMPNESS, S.S.; MORIS, $K$. The population of buried viable seeds in relation to contrasting pasture and soil types. Journal of Ecology, v.36, p.147-173, 1948.

CHRISTOFFOLETI, P. J.; CAETANO, R.S.X. Soil seed banks. Scientia Agricola, v.55, p.74-78, 1998.

CINTRA, L.F.D.; COELHO, Y da S. Caracterização física do solo submetido a práticas de manejo em pomar de laranja 'Baianinha'. Pesquisa Agropecuária Brasileira, v.18, p.173-179, 1983.

CLEMENTS, D.R.; BENOIT, D.L.; MURPHY, S.D.; SWANTON, C.J. Tillage effects on weed seed return and seedbank composition. Weed Science, v. 44, p.314-322, 1996.

COFFIN, D.P.; LAUENROTH, W.K. Spatial and temporal variation in the seed bank of a semiarid grassland. American Journal of Botany, v. 76, p.53-58, 1989.

CÓME, D. Germination. In: MAZLIAK, P. Croisance et développement. Physiologie Vegetale II. Paris, Hermann, 1982. p. 129-225.

COOPERCITRUS. Os avanços do manejo integrado de pragas. Informativo Coopecitrus, v.4, p.8-12, 1990. 
COUSENS, R.; MORTIMER, M. Processes involved in the regulation of population density. In: Dynamics of weed populations. Cambridge: Cambridge University Press, 1995. p. 86-134.

COUSENS, R.; MOSS, S.R. A model of the effects of cultivation on the vertical distribution of the seeds within the soil. Weed Research, v.30, p.61-70, 1990.

DE NEGRI, J.D. Cultura do Citrus. Campinas: CATI, 1996. 35p. (Boletim Técnico da Coodernadoria de Assistência Técnica Integral, 228).

DEKKER, J.; DEKKER, B. HILHORST, H. KARSSEN, C. Weedy adaptation in Setaria spp. IV. Changes in the germinative capacity of S. faberi (Poaceae) embryos with development from anthesis to after abscission. American Journal of Botany, v.83, p.979-991, 1996.

DERKESEN, D.A.; LAFOND, G.P.; THOMAS, A.G. et al. Impact of agronomic practices on weed communities: tillage systems. Weed Science, v.41, p.409-417, 1993.

DESSAINT, F.; CHADOEF, R.; BARRALIS, G. Etude de la dynamique communauté adventice: III. Influence à long terme des techniques culturales sur la composition spécifique du stock semencier. Weed Research, v.30, p.319-30, 1990.

DURIGAN, J.C. Controle do mato: produção sem perdas. Fundecitrus, v.78, p.12, 1996.

DURIGAN, J.C.; GALLI, A.J.B.; LEITE, G.J. Avaliação da eficiência da mistura de glyphosate e 2,4-D para o controle de plantas daninhas em citrus. CONGRESSO BRASILEIRO DE HERBICIDAS E PLANTAS DANINHAS, 17., Piracicaba. Resumos. Piracicaba: SBHPD, 1988. p.303-304. 
EGLEY, G.H. Ethylene, nitrate and nitrite interactions in the promotion of dark germination of common purslane seeds. Annals of Botany, v.53, p. 833840, 1984.

ESPEBY, L. Germination of weed seeds and competition in stands of weeds and barley influences of mineral nutrients. Crop Production Science, v.6, 1989.

FELLIPE, G.M.; POLO, M. Germinação de ervas invasoras: efeito da luz e escarificação. Revista Brasileira de Botånica , v.6, p.55-60, 1983.

FERNÁNDEZ-QUINTANILLA, C. Studying the population dynamics of weeds. Weed Research, v.25 p.443-47, 1988.

FERNÁNDEZ-QUINTANILLA, C.; SAAVEDRA, M.S; GARCIA TORRES, L. Ecologia de las malas hierbas. In: GARCIA TORRES, L.; FERNÁNDEZQUINTANILLA, C. Fundamentos sobre malas hierbas y herbicidas. Madrid: Mundi-Prensa, 1991. Cap.2, p.49-69.

FIGUEIREDO, J.O. de. Variedades copa de valor comercial. In: RODRIGUEZ, O.; VIÉGAS, F.; POMPEU Jr., J. et al. Citricultura brasileira. Campinas: Fundação Cargill, 1991, p.228-280.

FORCELLA, F.; LINDSTRON, M.J. Movement and germination of weeds in ridge-till crop production systems. Weed Science, v.36, p.56-59, 1988.

FREITAS, R.R. Dinâmica do banco de sementes em uma comunidade de plantas daninhas com aspecto da germinação e dorméncia de sementes de capim-marmelada (Brachiaria plantaginea (Link) Hitc). Lavras, 1990. 118p. Dissertação (M.S.) - Escola Superior de Agricultura de Lavras. 
FROUD-WILLIAMS, R.J.; CHANCELLOR, R.J.; DRENNAN, D.S.H. Influence of cultivation regime upon burid weed seed in arable cropping systems. Joumal of Applied Ecology, v.20, p. 199-208, 1983.

GALLAGHER, R.S.; CARDINA, J. Phytocrome-mediated Amaranthus germination I: effect of seed burial and germination temperature. Weed Science, v.46, p.48-52, 1998.

GALLI, A.J.B.; CARVALHO, J.E.B de. Mistura de herbicidas para o controle de plantas daninhas anuais na cultura dos citrus (Citrus sinensis (L.) Osbeck). Planta Daninha, v.8, p.45-51, 1985.

GELMINI, G.A. Agrotóxicos: legislaçăo básica. Campinas: Fundação Cargill, 1991. 838p. (Série Técnico-Científico, 175).

GELMINI, G.A. Herbicidas: indicações básicas para a cultura do milho. CATI, 1995. 36p. (Manual, 54).

GELMINI, G.A. Herbicidas: indicaçōes básicas. Campinas: Fundação Cargill, 1988. 334p.

GORRESIO-ROIZMAN, L. Fitossociologia e dinâmica do banco de sementes de populaçőes arbóreas de floresta secundária em São Paulo. São Paulo, 1993. 148p. Dissertaçăo (M.S.) - Universidade de Săo Paulo.

GOYEAU, H.; FLABET, G. Etude du stock de semences de mauvaises herbes dans le sol: le problème de l'énchantillonnage. Agronomie, v.2, p.545-552, 1982.

GRANATOS, F.L.; TORRES, L.G. Seed bank and other demographic parameters of broomrape (Orobanche crenata Forsk) populations in faba bean (vicia faba L.). Weed Research, v.33, p.319-327, 1993. 
GRIME, J.P. Estratégias de adaptacion de las plantas y processos que controlam la vegetacion. México: Noriega, 1989. 227p.

GROSS, K.L.A. A comparison of methods for estimating seed numbers in the soil. Journal of Ecology, v.78, p.1079-1093, 1990.

GROTH, D.; LIBERAL O.T. Catálogo de identificação de sementes. Campinas: Fundação Cargill, 1988. p.

GUTTERMAN, Y. Influences on seed germinability phenotypic maternal effects during seed maturation. Israel Journal of Botany, v. 29, p.105-117, 1980/1981.

HARRIS, S.M.; DOOHAN, D.J.; GORDON, R.J.; JENSEN, K.I.N. The effects of thermal time and soil water on emergence of Ranunculus repens. Weed Research, v.38, p.405-412, 1998.

HENDRICKS, S.B.; TAYLORSON, R.B. Promotion of seed germination by nitrate, nitrite, hidroxylamine and ammonium salts. Plant Physiology, v.54, p.304-309, 1974.

HILL, T.A. The biology of weeds. London, Edward Arnold, 1977. p.

HSIAO, A.I; QUICK, W.A. Actions of sodium hypoclorite and peroxide on seed dormancy and germiantion of wild oats (Avena fatua, L.). Weed Research, v. 24, p. $411-419,1984$.

HUMPHREYS, L.R. Environmental adaptation of tropic pasture plants. London: Macmillan Publishers, 1981. 261p.

JAIN, S.K. Variation and adaptive role of seed dormancy in some grassland species. Botanical Gazette, v.143, p.101-106, 1982. 
KARSSEN, C. M. Seasonal patterns of dormancy in weed seeds. In: KHAN, A.A.(Ed.). The physiology and biochemistry of seed development, dormancy and germination. New York: Elsivier Biomedical Press, 1982. p.243-270.

KHAN, A.A. Hormonal regulation of primary and secondary seed dormancy. Israel Journal of Botany, v.29, p.207-221, 1980/1981.

KROPÁC, Z. Estimation of weed seeds in arable soil. Pedobiologia, v.6, p.105128, 1966.

LEBARON, H.M. Distribution and seriousness of herbicide resistant weed infestations worldwide. In: CASELEY,J.C.; CUSSANS, G.W.; ATKIN, R.C. Herbicide resistance in weeds and crops. Oxford: ButterworthHeinemann, 1991. p.27-43.

LOPEZ, C.; ABRAMOVSKY, P.; VERDIER, J.L. et al. Estimation du stock dans le cadre d'un essai étudiant l'influence de systèmes culturaux sur l'évolution de la flore adventice. Weed Research, v.28, p.215-221, 1988.

LORENZI, H. Manual de identificação e controle de plantas daninhas: plantio direto e convencional. Nova Odessa: Plantarum, 1994. 299p.

LORENZI, H. Plantas daninhas do Brasil: terrestres, aquáticas, parasitas, tóxicas e medicinais. Nova Odessa, 1982. 425p.

LUSCHEI, E.C.; BUHLER, D.D.; DEKKER, J.H. Effect of separating giant foxtail (Setaria faberi) seeds from soil using potassium carbonate and centrifugation on viability and germination. Weed Science, v.46, p.545-548, 1998. 
MACHADO NETO, J.G. Efeitos do uso contínuo de herbicidas residuais na composição específica da comunidade infestante e na presença de resíduos no solo de um pomar de citros (Citrus sinensis (L.) Osbeck). Piracicaba, 1987, 117p. Dissertação (M.S.). Escola Superior de Agricultura 'Luiz de Queiroz'.

MALONE, C.R. A rapid method for enumeration of viable seeds in soil. Weeds, v.15, p.381-382, 1967.

MARCONDES, D.A.S.; BENATTI Jr., A.; PITELLI, R.A. et al. Controle integrado de plantas daninhas. São Paulo: CREA, 1985. 161p.

MARTINS, C.C.; SILVA, W.R. da. Estudos de bancos de sementes do solo. Informativo Abrates, v.4, p.49-56, 1994.

MAYOR, J.P.; DESSAINT, F. Influence of weed management strategies on seedbank diversity. Weed Research, v.30, p.95-105, 1988.

MONTÉGUT, J. Ecologie de la germination des mauvaises herbs. In: CHAUSSAT, R.; LE DEUNFF, Y. (Eds.). La germination des semences, Paris: Gauthier-Villars, 1975. p. 191-217.

MORTIMER, A.M. The biology of weed. In: HANCE, R.J.; HOLLY, K. (Eds.). Weed control handbook: principles. London: Blackwell Scientific Publications, 1990. p.1-42, Cap.1.

MURDOCH, A.J.; ELLIS, R.H. Longevity, viability and dormancy. In: FENNER, $M$. (Ed). Seeds: the ecology of regeneration in plant communities. Great Britain, Wallingford: CAB International. p.193-229, 1992.

MUSIL, A.F. Identificação de sementes de plantas cultivadas e silvestres. Brasília: Ministério da Agricultura/AGIPLAN, 1977. 299p. 
NAYLOR, J.M. Studies on the genetic control of some physiological processes in seeds. Canadian Journal of Botany, v.61, p.3561-3567, 1983.

NIKOLAEVA, M.G. Factors controlling the seed dormancy pattern. In: KHAN, A.A. (Ed). The physiology and biochemistry of seed dormancy and germination. Amsterdam: North Holland Publishing, 1977. p.51-74.

OCAMPO RUIZ, R.A.; MEDINA PITALUA, J.L.; DOMÍNGUES VALENZUELA, J.A. Influencia de la temperatura, luz, estratificación y escarificación mecánica sobre la germinación de cuatro especies de malezas de importancia agrícola en Mexico. Revista Chapingo, v.15, n.67-68, p.161$171,1990$.

PETTO NETO, A. Práticas culturais: In: RODRIGUEZ, O.; VIÉGAS, F.; POMPEU Jr. J. et al. Citricultura brasileira. Campinas: Fundação Cargill, 1991. p.476-490.

PIERCE, S.M.; COWLING, R.M. Dynamics of soil-stored seed banks of six shrubs in fire-pone dune fymbos. Journal of Ecology, v.79, p.731-747, 1991.

PITELLI, R.A. Ervas daninhas x culturas anuais. Granja, v.36, p.56-61, 1980.

RICE, K.J. Impacts of seed banks on grassland community structure and population dynamics. In: LECK, M.A.; PARKER, V.T; SIMPSON, R.L. (Ed). Ecology of soil seed banks, London: Academic Press, 1989. p.69-86.

ROBERTS, H.A. Seed banks in the soil. Advances in Applied Biology, v.6, p.1-55, 1981.

ROBERTS, H.A. Viable weed seeds in cultivated soils. Report of the National Vegetable Research Station, 1970. p.25-38. 
ROBERTS, H.A.; DAWKINS, P.A. Effect of cultivation on the number of viable weed seeds in soil. Weed Research, v.7, p.290-301, 1967.

ROBERTS, H.A.; NEILSON, J.E. Changes in the soil seed bank of four longterm crop/herbicide experiments. Journal of Applied Ecology, v.18, p.661$668,1981$.

ROBERTS, H.A.; NEILSON, J.E. Seed bank of soil under vegetable cropping in England. Weed Research, v.22, p. 13-16, 1982.

RODRIGUES, B.N.; ALMEIDA, F.S. Guia de herbicidas. 4. ed. Londrina:1998. $648 p$.

RODRIGUEZ, O. Manejo de solo em pomar citrico. Agronômico, v.9, p.17-24, 1957.

ROUW, A.; OERS, C. Seeds in a forest soil and their relation to shifting cultivation in the Ivory Coast. Weed Research, v.28, p.373-381, 1988.

SALZMAN, F.P.; SMITH, R.J.; TALBERT,R.E. Suppression of red rice (Oryza sativa) seed production with fluazifop and quizalofop. Weed Science, v. 36, p. $800-803,1988$.

SCHREIBER, M.M. Influence of tillage, crop rotation, and weed management on giant foxtail (Setaria faberi) population dynamics and corn yield. Weed Science, v.40, p.645-653, 1992.

SCHWEIZER, E.E.; ZIMDAHL, R.L. Weed seed decline in irrigated soil after six years of continuous corn (Zea mays) and herbicides. Weed Science, v. 32, p. $76-83,1984$.

SILVERTOWN, J.W. Phenotypic variety in seed germination behavior the ontogeny and evolution of somatic polymorphism in seeds. American Naturalist, v.124, p.1-16, 1984. 
SIMPSON, R.L.. LECK, M.A.; PARKER, V.T. Seed banks: General concepts and methodological issues. In: LECK, M.A.; PARKER, V.T; SIMPSON, R.L.. (Ed). Ecology of soil seed banks, London: Academic Press, 1989. p.3-8.

SPRANKE, P.; MEGGITT, W.F.; PENNER, D. Absorpt, action and translocation of glyphosate. Weed Science, v.23, p.235-240, 1975.

STANDIFER, L.C. A technique for estimating weed seed populations in cultivated soil. Weed Science, v.28, p.134-138, 1980.

STARICKA, J.A.; BURFORD, P.M.; ALLMARAS, R.R.; NELSON, W.W. Tracing the vertical distribution of simulated shattered seeds as related to tillage. Agronomy Journal, v.82, p.1131-1134, 1990.

STEINBAUER, G.P.; GRIGSBY, B. Interactions of temperature, light and moistening agent in the germination of weed seeds. Weeds, v.5, p.681-688, 1957.

TEMPLETON, A.R.; LEVIN, D.A. Evolutionary consequences of seed pools. American Naturalist, v.114, p.232-249, 1979.

THOMPSON, K. Seeds and seeds banks. New Phytopatologist, v.10, p.23-34, 1987.

THOMPSON, K. The functional ecology of seed banks. In: FENNER, M. (Ed). Seeds: the ecology of regeneration in plant communities. Great Britain, Wallingford: CAB International. p.231-258, 1992.

THOMPSON, K.; GRIME, J.P. Seasonal variation in the seed banks of herbaceous species in ten contrasting habitats. Journal of Ecology, v.67, p.893-921, 1979. 
TILMAN, D. Mechanisms of plant competition for nutrients; the elements of a predictive theory of competition. In: GRACE, J.; TILMAN, D. (Eds.). Perspectives on plant competition. San Diego: Academic Press, 1990. p.146-173.

VEGIS, A. Dormancy in higher plants. Annual Review of Plant Physiology, v. 15, p. $185-215,1964$.

VICENT, E.M.; ROBERTS, E.H. The interaction of light, nitrate and alternating temperature in promoting the germination of dormant seeds of common weed species. Seed Science \& Technology, v.5, p.650-670, 1977.

VICTORIA FILHO, R. ; CHRISTOFFOLETI, P.J. Interaction effect between row chemical weed control versus inter-row mechanical and cultural weed control of citrus crop on the infestation and physical/chemical soil proprities. Weed Science Society of America, 1997. Orlando Abstracts, 1997. p.101.

VICTORIA FILHO, R.; DURIGAN, J.C.; CAETANO, A.A. Uso de herbicidas em citrus. In: RODRIGUEZ, O. (Ed.). Citricultura Brasileira. Campinas: Fundação Cargill.1991. p.493-518. V.2.

VIDAL-TORRADO, P.; G. SPAROVEK. Mapa pedológico escala 1:10000 detalhado do campus 'Luiz de Queiroz', Universidade de Săo Paulo. Piracicaba/SP, 1993. (Não publicado).

VITTI, G.C. Nutrição e crescimento de plantas citricas. In: SEMINÁRIO INTERNACIONAL DE CITRUS- FISIOLOGIA, 1992, Bebedouro. Anais. Campinas: Fundação Cargill, 1992. p.132-162.

VOLL, E.; GAZZIERO, D.L.P.; KARAM, D. Dinâmica de populações de Brachiaria plantaginea (Link) HITCH. sob manejo de solo e de herbicidas. 2. Emergência. Pesquisa Agropecuária Brasileira, v.30, p.27-35, 1996. 
WESSON, G.; WAREING, P.F. The induction of light sensitivity in weed seeds by burial. Journal of Experimental Botany, v.20, p.414-425, 1969.

YENISH, J.P.; DOLL, J D.; BUHLER, D.D. Effects of tillage on vertical distribution and viability of weed seed in soil. Weed Science, v.40, p.429$433,1992$.

YOUNG, J.A; EVANS, R.A. Responses of weed populations to human manipulations of the natural environment. Weed Science, v.24, p.186-190, 1976. 


\section{APÊNDICE 1}

Relação das espécies encontradas pelos métodos de germinação e separação de sementes.

ESPÉCIES

CóDIGOS

Monocotiledoneae

Cyperaceae

Cyperus ferax

CYPFE

Cyperus rotundus

CYPRO

Gramineae

Cenchrus echinatus $L$.

CCHEC

Digitaria horizontalis Willd.

DIGHO

Digitaria insularis (L.) Mez ex Ekman

DIGIN

Panicum maximum Jacq

PANMA

Rhynchelytrum repens (Willd.) Hubbart.

Setaria geniculata (Lam.) Beauv.

RHYRE

SETGE

Dicotiledoneae

Amaranthaceae

Amaranthus viridis $L$.

AMAVI

Gomphrena celosioides Mart

Asteraceae

Ageratum conyzoides $L$.

AGECO

Ambrosia elatior $L$.

AMBEL

Bidens pilosa, $L$.

BIDPI

Emilia sonchifolia DC.

EMISO

Galinsoga parviflora Cav.

GASPA

Gnaphalium sp. 
Commelinaceae

Commmelina benghalensis $L$.

COMBE

Euphorbiaceae

Euphorbia hirta L.

EPHHI

Fabaceae

Indigofera hirsuta $L$.

INDHI

Labiatae

Hyptis suaveolens (L.) Poit.

HYPSU

Malvaceae

Sida sp.

SIDCO, SIDDZ, SIDRH

Molluginaceae

Mollugo verticillata $L$

MOLVE

Portulacaceae

Portulaca oleracea $L$.

POROL

Rubiaceae

Richardia brasiliensis (Gomez)

RCHBR

Solanaceae

Solanum americanum Mill.

SOLAM 


\section{APÊNDICE 2}

Avaliação da flora daninha antes da instalação do experimento.
1. A. elatior
2. A. viridis
3. B. pilosa
4. B. rhomboidea
5. C. benghalensis
6. C. bonariensis
7. C. dactylon
8. C. glandulosus
9. C. rotundus

10. D. horizontalis

11. D. insularis

12. E. pilosa

13. E. sonchifolia

14. G. celosioides

15. Gnaphalium sp.

16. H. suaveolens

17. I. hirsuta

18. J. hirta

19. L. virginucum

20. P. maximum

21. P. oleracea

22. $R$. brasilienis

23. $R$. repens

24. C. ferax

25. C. ambrosioides

26. S. americanum 
27. S. geniculata

28. S. oleracea

29. Sida sp. 